\title{
ESTUDO COMPARATIVO SOBRE A \\ COLONIZAÇÃo POR LEVEDURAS NO SULCO \\ Gengival de Diabéticos TIPO 1
}

\section{Nelí Pialarissi CaÇAdor}

Dissertação apresentada à Faculdade de Odontologia de Bauru, da Universidade de São Paulo, como parte dos requisitos para obtenção do título de Mestre em Odontologia, área de Periodontia.

(Edição revisada) 


\section{ESTUDO COMPARATIVO SOBRE A \\ COLONIZAÇÃo POR LEVEDURAS NO SULCO \\ Gengival de Diabéticos TIPO 1}

\section{Nelí Pialarissi CaÇAdor}

Dissertação apresentada à Faculdade de Odontologia de Bauru, da Universidade de São Paulo, como parte dos requisitos para obtenção do título de Mestre em Odontologia, área de Periodontia.

(Edição revisada)

Orientador: Prof. Dr. Sebastião Luiz Aguiar Greghi 


\begin{tabular}{|c|c|}
\hline \multirow[t]{3}{*}{ C113e } & $\begin{array}{l}\text { Caçador, Nelí Pialarissi } \\
\text { Estudo Comparativo sobre a Colonização por } \\
\text { Leveduras no Sulco Gengival de Diabéticos Tipo } 1 \text { / } \\
\text { Nelí Pialarissi Caçador. - Bauru, } 2003 . \\
\text { 110p. : il. ; } 30 \mathrm{~cm} \text {. }\end{array}$ \\
\hline & $\begin{array}{cc}\text { Dissertação } & \text { (Mestrado) }- \\
\text { Odontologia de Bauru. Universidade de São Paulo }\end{array}$ \\
\hline & $\begin{array}{l}\text { Orientador: Prof. Dr. Sebastião Luiz Aguiar } \\
\text { Greghi }\end{array}$ \\
\hline
\end{tabular}

Autorizo, exclusivamente para fins acadêmicos e científicos, a reprodução total ou parcial desta dissertação por processos fotocopiadores e outros meios eletrônicos.

Nelí Pialarissi Caçador

Data: Março de 2003

Projeto de pesquisa aprovado pelo Comitê de Ética em Pesquisa da Faculdade de Odontologia de Bauru Universidade de São Paulo, na reunião de 23 de setembro de 2002.

Ofício n. CEP/0182002/FOB-USP. 


\section{Nelí PIALARISSI CaÇADOR}

09 de maio de 1964

Apucarana - Pr

$1982-1985$

$1987-1988$

1990

$2001-2003$

Associações
Nascimento

Curso de Odontologia na Universidade Estadual de Londrina

Curso de Pós-Graduação em Periodontia, a nível de Especialização, na FUNBEO-FOBUSP

Efetivada como Docente da Disciplina de Semiologia e Diagnóstico Bucal do Curso de Odontologia da Universidade Estadual de Maringá

Curso de Pós-Graduação em Periodontia, a nível de Mestrado, na Faculdade de Odontologia de Bauru da Universidade de São Paulo

AONP - Associação Odontológica Norte do Paraná

ABO - Associação Brasileira de Odontologia 
DEDICATÓRIA 


\section{"O nosso caminho é interior. Este é o}

caminho mais difícil, a viagem mais dolorosa.

Somos responsáveis por nosso próprio aprendizado. Esta responsabilidade não pode ser colocada nas mãos de algum guru. O reino de Deus está dentro de nós. "

\section{Brian Weiss}


À MINHA FAMÍLIA:

"É fácil ler e falar sobre amor, caridade e fé. Mas fazer e sentir, requer este estado de consciência. Atinge-se o estado permanente pelo comportamento físico, pelos atos e ações, pela prática. É pegar algo quase místico e transformá-lo em algo familiar e cotidiano através da prática, torná-lo um hábito.

Brian Weiss

A meu filho Luís Gustavo que me permitiu sentir como se tocasse Deus com as mãos; que muitas vezes me viu ausente mesmo estando presente, mas que com seu amor e ingenuidade me esperou.... 
Ao meu marido Walangiery que me incentivou e foi um grande amigo e companheiro, respeitando meus sonhos e meus deveres e que nunca deixará de ocupar um lugar especial em meu coração, bem como jamais deixará de caminhar junto comigo, de mãos dadas com o nosso filho.

A meus pais Osvaldo e Cida cuja vida os ensinou a serem sábios e cuja sabedoria me conduziu para minha realização.

Aos meus irmãos, Nelci e Nelson e meus cunhados, Denise e Sérgio, que torceram por mim e, como padrinhos de meu filho, contribuíram nas divisões de tarefas...

Aos meus sogros, Maria Luiza e Sebastião que como segundo pais me apoiaram e auxiliaram muito, sendo também pais de meu filho, substituindome nas minhas ausências como mãe.

Aos meus filhos- sobrinhos, Maria Fernanda, Ana Elisa, Sérgio Henrique, Rodrigo, Júnior e Ricardo pelas "tantas" vezes que colaboraram na solução das dificuldades que surgiram nesta trajetória.

Aos meus tios-irmãos Waldemar e Cida que estiveram presentes nas minhas trajetórias profissionais e pessoais, apoiando-me....

Meu Muito Obrigada e Minha Dedicatória. 
AGRADECIMENTOS 
AOS MEUS PROFESSORES, NA PESSOA DE MEU ORIENTADOR

SEBASTIÃO LUIZ DE AGUIAR GREGHI

"A semente fica muito tempo oculta sob a terra e, se desistirmos de regar o solo, perderemos a beleza, a sombra e o fruto da árvore que poderá despontar e crescer. Deem início ao processo, pois a felicidade que procuram não está no fim do caminho, mas durante o percurso. E saibam que cada ser humano que entra em harmonia com seu núcleo essencial de amor, ao construir sua própria felicidade, está doando sua parcela de contribuição para a felicidade da Terra. "

Brian Weiss. 
Agradeço a Deus de quem recebi o dom da vida, que me molda, ora de forma, momentaneamente, incompreensível, mas com resultados indiscutíveis.

Ao Prof. Dr. Newton E. de Moraes cujo idealismo e dedicação são exemplos profissionais, bem como suas preocupações nos transmitiram todo o carinho e torcida de um pai.

A querida Prof. Dra. Maria Fidela de Lima Navarro que através do "jogo do contente" (Pollyana) nos ensinou ater perseverança e incentivou-nos a vencer os obstáculos.

Ao Prof. Dr. Euloir Passanezi, cujos sorriso, otimismo, incansável disposição na busca do conhecimento, demonstra a competência e a segurança de um educador profissional, correspondendo às necessidades para o aprendizado.

Ao Prof. Dr. Deoclécio Nahás, como sua ex-aluna senti a sua preocupação na transmissão de sua experiência profissional, para obter os resultados esperados. Lamento a vida ter interceptado a oportunidade de uma nova convivência.

Ao Prof. Dr. Lauris, cuja seriedade profissional e habilidade e estatística não o tornam um ser frio e distante, mostrando-se atencioso em todas as necessidades apresentadas pelos mestrandos.

Aos demais professores deste Curso de Pós-Graduação, cada qual com sua técnica de ensino e bagagem de informações, foram exemplos vivos da metodologia de ensino e respeito humano para com o aluno. 
"Nos relacionamentos, nossos 6otões são acionados e nós reagimos. Já aprendemos a negociar, dialogar e perdoar, ou usamos a violência o autoritarismo e a vingança? Somos capazes de nos aproximar dos outros com compreensão, amor e compaixão, ou reagimos com medo, egoísmo e rejeição? Sem relacionamentos, nunca poderíamos testar essas coisas nem testar nosso progresso. 
Aos meus companheiros, Carrilho, Edna, Feis, Flávio, Geraldo, João, Lucinara, Maria Luiza e Paulo, que me mostraram que nossos limites e nossos inimigos estão dentro de nós mesmos.

Aos professores, companheiros de trabalho, do Curso de Odontologia, da Universidade estadual de Maringá, em especial a Lilian Cristina Vessoni Iwaki, Mariliani Chicarelli Silva e João Carlos Miguel, que me substituíram no meu afastamento.

A todos que colaboraram direta ou indiretamente para a realização deste Curso de Mestrado.

Muito obrigada. 
"Existem muitas outras árvores nesta bela floresta, todas ligadas entre si através do sistema de raízes do solo. Ainda que possa haver uma folha distante que pareça bem diferente de nós e muito remota, somos ligados a essa folha, ligados a todas as folhas."

\section{Brian Weiss}


Agradeço ainda:

A Faculdade de Odontologia de Bauru, da Universidade de São Paulo, através de sua Diretora Doutora Maria Fidela de Lima Navarro.

A Comissão de Pós-Graduação da Faculdade de Odontologia de Bauru, através de seu presidente Dr. José Carlos Pereira.

À Universidade Estadual de Londrina, ao Centro de Ciências da Saúde e Centro Odontológico do Norte do Paraná.

Ao secretário do Mestrado Interinstitucional Faculdade de Odontologia de Bauru- Universidade Estadual de Londrina e demais associadas, Ricardo Aparecido Campos.

À assessora da diretoria da Faculdade de Odontologia de Bauru e do Mestrado Interinstitucional da Faculdade de Odontologia de BauruUniversidade Estadual de Londrina e demais associadas, Elizabeth $\mathbf{S}$.

\section{Cariani.}

Aos professores Terezinha e Robinson, do Departamento de estatística da Universidade Estadual de Maringá pelo auxílio na análise dos resultados estatísticos.

Aos funcionários da biblioteca da Universidade de São Paulo e da Universidade Estadual de Londrina.

Aos funcionários do Curso de Mestrado em Periodontia, da Faculdade de Odontologia de Bauru, da Universidade de São Paulo, Ivania, Edilaine, Débora, Neusa, e Marcos, pela paciência e carinho a nós dedicados.

À disciplina de Microbiologia Clínica da Universidade Estadual de Maringá, nas pessoas de Terezinha Svidzinski, Civaldo, Márcia, Kallen e Renata.

Aos meus queridos pacientes que foram literalmente "pacientes" e, mais ainda, amigos, ao torcer pelos nossos resultados. 
Ao Dr. José Cervantes e à Associação de Diabéticos de Apucarana que, prestimosamente, encaminharam os pacientes. Às minhas companheiras de trabalho, Carla e Fabiana, que viviam intensamente as minhas alegrias e tristezas desta trajetória.

Aos meus queridos amigos Paulo e Luciângela, que procuraram me transmitir tranquilidade para prosseguir....

Aos doutores Nelma, Eliane e Cláudio que me deram suporte para passar por uma fase tão delicada,

Ao Dr. Hugo Dehé e equipe e Sr. José Pereira e família que me deram suporte espiritual, mantendo a centelha divina acessa em meu interior.

Às minhas colegas Maria Celeste, Cláudia e Renata que me apoiaram profissionalmente e fraternalmente nas minhas ausências profissionais.

Aos meus companheiros, Adriane, Walderez e Aparecido pela sincera amizade ....

Ao Sylvio que muito me ensinou sobre a vida........ 


\section{Sumário}

Listas de Figuras.......................................................................... XV

Listas de Tabelas ......................................................................... xvii

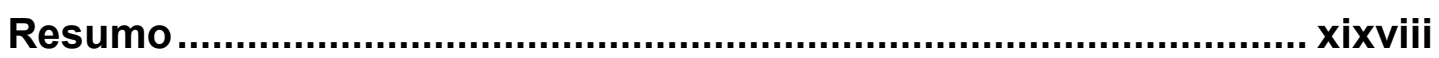

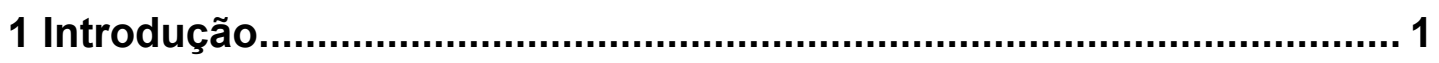

2 Revisão de Literatura.................................................................... 7

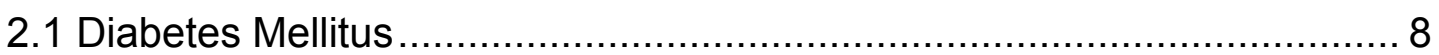

2.2 Diabetes Mellitus e Doença Periodontal ......................................... 11

2.3 Leveduras e Doença Periodontal e Diabetes Mellitus .......................... 26

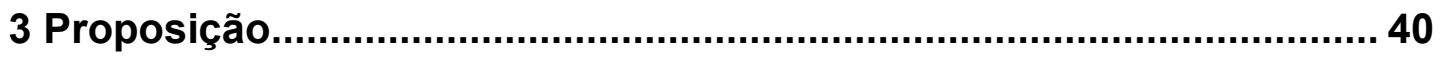

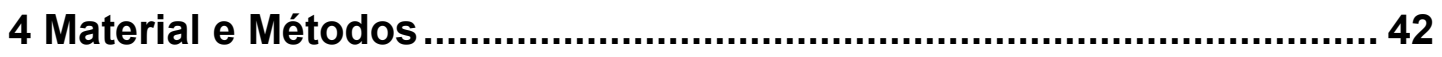

4.1 Seleção dos Pacientes.............................................................. 43

4.2 Comitê de Ética em Pesquisa e Instruções Gerais aos Pacientes ......... 44

4.3 Anamnese e Exame Periodontal ..................................................... 44

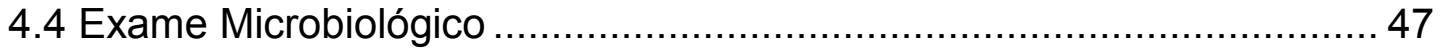

4.5 Análise Estatística .................................................................... 49

5 Resultados....................................................................................... 50

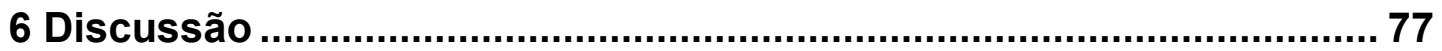

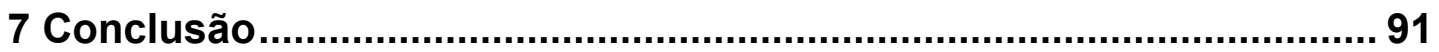

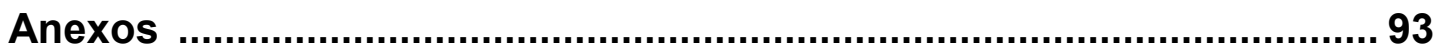

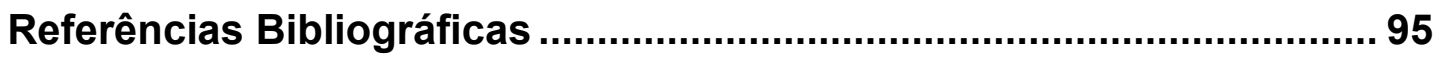

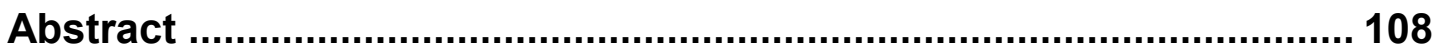


LISTAS 


\section{LISTAS DE FIgURAS}

FIGURA 1 - Gráfico ilustrativo do perfil das amostras estudadas

FIGURA 2 - Gráfico ilustrativo da freqüência de lesões da mucosa bucal distribuídas nos grupos de pacientes pesquisados.

FIGURA 3 - Gráfico representativo dos valores médios do índice de placa. índice gengival e nível de inserção clínica dos grupos de pacientes estudados.

FIGURA 4 - Gráfico demonstrativo dos valores médios das profundidades de sondagem de até $3 \mathrm{~mm}$, entre 4 e 5 $\mathrm{mm}$ e igual ou superior a $6 \mathrm{~mm}$.

FIGURA 5 - Gráfico demonstrativo dos valores médios do índice de sangramento gengival nos grupos de paciente estudados.

FIGURA 6 - Gráfico que ilustra a freqüência de pacientes diabéticos tipo 1 ( $A$ e $B$ ) e dos pacientes controles quanto aos resultados das culturas de leveduras das amostras da cavidade bucal.

FIGURA 7 - Gráfico representativo dos valores médios do índice de placa. índice gengival e nível de inserção clínica dos pacientes com culturas positivas e negativas para leveduras.

FIGURA 8 - Gráfico demonstrativo dos valores médios das profundidades de sondagem de até $3 \mathrm{~mm}$, entre 4 e 5 $\mathrm{mm}$ e igual ou superior a $6 \mathrm{~mm}$ dos pacientes com culturas positivas e negativas para leveduras.

FIGURA 9 - Gráfico demonstrativo dos valores médios do índice de sangramento gengival nos grupos dos pacientes com culturas positivas e negativas para leveduras.

FIGURA 10 - Distribuição Bruta das culturas positivas das amostras isladas da cavidade bucal e os respectivos números de colônias de leveduras, por paciente.

FIGURA 11 - Gráfico ilustrativo da distribuição dos treze sítios da cavidade bucal com culturas positivas para leveduras......65

FIGURA 12 - Comparação entre pacientes diabéticos (grupo A + B) controles (grupo $\mathrm{C}$ ) quanto à presença de leveduras no sulco gengival 
FIGURA 13 - llustra a freqüência de leveduras isoladas conforme a espécie por sítio amostrado.

FIGURA 14 - Gráfico ilustrativo sobre a distribuição dos pacientes diabéticos tipo 1 conforme seu controle glicêmico (hemoglobina glicosilada).

FIGURA 15 - Valores médios do índice de placa índice gengival e nível de inserção dos pacientes diabéticos tipo 1 moderadamente controlados (DMC) e pobremente controlados (DPC).

FIGURA 16 - Valores médios das profundidades de sondagem em paciente diabéticos tipo 1 moderadamente controlados (DMC) e pobremente controlados (DPC).

FIGURA 17 - llustra os valores médios do índice de sangramento gengival (ISG) dos pacientes diabéticos tipo 1, moderadamente controlados (DMC) e pobremente controlados (DPC).

FIGURA 18 - llustra a freqüência observada das lesões de mucosa bucal conforme o comportamento glicêmico do paciente (moderadamente e pobremente controlado).

FIGURA 19 - Ilustra a freqüência de culturas positivas para leveduras das amostras isoladas da cavidade bucal de diabéticos tipo 1, em relação ao seu comportamento glicêmico.

FIGURA 20 - Gráfico ilustrativo da freqüência de leveduras por grupo diabético ( $\mathrm{A}$ e $\mathrm{B}$ ), de acordo com o comportamento glicêmico do paciente diabético (DMC- moderadamente controlado e DPC- pobremente controlado).

FIGURA 21 - Classificação dos pacientes pesquisados de acordo como o fluxo salivar e distribuídos em cada grupo pesquisado.

FIGURA 22 - Freqüência de leveduras de acordo com o tipo de fluxo salivar dos pacientes pesquisados. 


\section{LISTAS DE TABELAS}

TABELA 1 - Perfil das amostras.............................................. 52

TABELA 2 - Freqüência de lesões da mucosa bucal distribuídas nos grupos pesquisados.

TABELA 3 - Valores médios (x) e desvio padrão (dp) dos índices periodontais clínicos de pacientes dos grupos diabéticos tipo 1 ( $\mathrm{A}$ e $\mathrm{B}$ ) e dos pacientes controles (C).

TABELA 4 - Comparações dos índices periodontais clínicos entre os grupos três grupos s pelo teste de Dunn.

TABELA 5 - Freqüência dos pacientes diabéticos tipo1 (A e B) e controles (C) quanto aos resultados das culturas de leveduras das amostras da cavidade bucal.

TABELA 6 - Índices periodontais clínicos dos pacientes com culturas positivas $(n=8)$ ou negativas $(n=6)$ para leveduras.

TABELA 7 - Distribuição Bruta das culturas positivas das amostras isoladas da cavidade bucal e os respectivos números de colônias de leveduras, por pacientes

TABELA 8 - Distribuição dos treze sítios da cavidade bucal que apresentaram culturas positivas de leveduras.

TABELA 9 - Comparação entre presença de leveduras nos sulcos comprometidos e saudáveis, dos diabéticos $(A+B)$ e controles (C)

TABELA 10 - Leveduras isoladas conforme a espécie por sítio amostrado.

TABELA 11 - Distribuição dos pacientes diabéticos tipo1 conforme seu controle glicêmico (hemoglobina glicosilada).

TABELA 12 - Valores médios e desvios padrões dos índices periodontais clínicos dos pacientes diabéticos tipo1 moderadamente controlados (DMC) e pobremente controlados (DPC).

TABELA 13 - Freqüência observada das lesões de mucosa bucal conforme o comportamento glicêmico do paciente moderadamente e pobremente controlado

TABELA 14 - Freqüência de culturas positivas para leveduras das amostras isoladas da cavidade bucal de diabéticos tipo 1 , em relação ao seu comportamento glicêmico. 
TABELA 15 - Freqüência de leveduras por grupo diabético (A e B), de acordo com o comportamento glicêmico do paciente (DMC - moderadamente controlado e DPC pobremente controlado).

TABELA 16 - Classificação dos pacientes pesquisados de acordo como o fluxo salivar e distribuídos em cada grupo pesquisado.

TABELA 17 - Freqüência de leveduras de acordo com o tipo de fluxo salivar dos pacientes pesquisados. 
RESUMO

$\longrightarrow$ 


\section{RESUMO}

Comparou-se pacientes diabéticos tipo $1 \mathrm{com}$ pacientes controles saudáveis, para avaliar as condições periodontais e da mucosa, identificar, qualificar e inter-relacionar, com o nível glicêmico do diabético, a presença de leveduras na gengiva e na saliva, através de: teste de hemoglobina glicosilada, índice de placa, índice gengival, índice de sangramento gengival, o nível de inserção, a profundidade de sondagem, exame radiográfico, inspeção da mucosa, teste de fluxo salivar e exame microbiológico. As diferenças não foram significantes quanto às condições periodontais e de mucosa, entre os pacientes, nem quanto à prevalência de leveduras entre os locais amostrados, exceto que os pacientes diabéticos mais velhos apresentaram nível de inserção clínica $77 \%$ maior que os mais jovens e o dobro de leveduras que os demais grupos. A C. albicans foi a levedura mais freqüente. Concluiu-se que houve uma leve tendência dos pacientes diabéticos apresentarem uma susceptibilidade aumentada à doença periodontal e maior frequência de leveduras, não podendo generalizar e estender os resultados de uma população tão pequena, sugerindo que se avalie uma população maior. 
1 INTRODUÇÃ 


\section{INTRODUÇÃO}

Diabetes Mellitus é uma doença metabólica crônica, que se caracteriza pela hipofunção ou ausência de função das células beta das ilhotas de Langerhans no pâncreas ${ }^{9}$, conduzindo a um alto nível de glicose no sangue e excreção desta na urina, resultando em uma tríade clássica: a polidipsia, a poliúria e a polifagia ${ }^{52} \mathbf{3 9}$.

Nos Estados Unidos estimava-se que existiam de 12 a 14 milhões de pacientes diabéticos ${ }^{41,42}$, cuja prevalência vem aumentando nos últimos 35 anos, chegando a 13.000 novos casos a cada ano, constituindose em uma das doenças crônicas mais comuns ${ }^{74}$. Esse incremento justificou-se pelo aumento de fatores de risco, como a obesidade, a vida sedentária e o envelhecimento da população, além da diminuição da mortalidade dos diabéticos e mudanças nos critérios diagnósticos da doença. No Brasil, de acordo com as fontes epidemiológicas do MINISTÉRIO DA SAÚDE ${ }^{45}$, em 1992, $7,60 \%$ dos brasileiros eram diabéticos, estimando-se 12,46 milhões de acometidos. Aproximadamente $10 \%$ dos casos são classificados como diabetes mellitus tipo 1, também chamados insulino-dependentes, resultantes da ausência acentuada e/ou absoluta de insulina promovida pela destruição das células beta do pâncreas, usualmente iniciada antes dos 20 anos, caracterizada pela elevação significativa da glicose no plasma sangüíneo, ocorrendo alterações no metabolismo das lipoproteínas e dos aminoácidos, conforme ${ }^{43}$.

O diabetes mellitus pode trazer complicações associadas a um controle glicêmico deficiente, refletindo no agravamento do quadro e produzindo custos consideráveis para o paciente e para a sociedade. Entres os fatores favoráveis para o desenvolvimento destas complicações estão as infecções ${ }^{74}$. 
Clinicamente, em indivíduos diabéticos, é mundialmente aceita sua predisposição a infecções, especialmente quando há falta de controle do diabetes mellitus, assim como o agravamento de infecções e do quadro glicêmico, ocorrendo o favorecimento de vários fatores à instalação da doença periodontal ${ }^{39}$. Considerando que a doença periodontal é resultante da inter-relação dos microorganismos com o sistema imune do hospedeiro no ambiente periodontal ${ }^{33}$, conduzindo à destruição do ligamento periodontal ${ }^{59}$ e ponderando as diferenças nos métodos diagnósticos, tanto da doença periodontal, como do diabetes mellitus, poder-se-ia justificar o fato de que nem todos os pacientes diabéticos desenvolvessem problemas periodontais ${ }^{39}$.

A gengivite e a doença periodontal são mais prevalentes no diabetes mellitus, em especial em indivíduos mais velhos e não controlados, 76. Em diabéticos tipo 1 não controlados, crianças e adultos, é comum encontrar periodontite agressiva, caracterizada pela perda severa e progressiva do osso alveolar e de inserção, com frequentes micro abcessos múltiplos e aumento do volume gengival ${ }^{39,44}$, observando-se maior profundidade de sondagem e perda óssea nos casos de longa duração do que nos de curta duração ${ }^{31}$.

A implicação do diabetes mellitus no periodonto tem sido amplamente explorada. No entanto, o contrário não tem sido observado em igual intensidade, sendo que os estudos que envolvem a influência da doença periodontal no diabetes mellitus têm se limitado a estudos dos resultados do tratamento periodontal, sobre o controle metabólico do diabetes mellitus ${ }^{72}$. Sobre esta discussão, pôde-se levantar duas hipóteses: (a) a hiperglicemia e a hiperlipidemia, consequências diretas do diabetes mellitus, provocariam alterações metabólicas que exacerbariam a periodontite inflamatória induzida por bactérias ou que (b) uma combinação "infeliz" de genes produziria um hospedeiro que, sob ação de fatores ambientais estressantes, poderia desenvolver tanto a periodontite como o diabetes. 
Quanto à ação que a infecção periodontal exerceria sobre o controle glicêmico, as evidências têm se baseado nas investigações da relação entre resistência insulínica e doenças inflamatórias do tecido conjuntivo, outras doenças e infecções agudas. A alta vascularidade do tecido periodontal inflamado atuaria como se fosse uma área endócrina, permitindo a ação do fator de necrose tumoral alfa, que agiria no metabolismo dos lipídios, como antagonista da insulina e de outros mediadores inflamatórios, como a interleucina 6 e 1, também antagonistas da insulina e produzidas pelas bactérias anaeróbicas gram negativas, predominantes na doença periodontal e que mostraram ter efeitos no metabolismo da glicose e dos lipídios. Desta forma, estudos terapêuticos ${ }^{68} \mathrm{e}$ de avaliações clínicas ${ }^{6,68}$ demonstraram o efeito adverso da periodontite sobre o controle glicêmico. No entanto ${ }^{75}$, nem todos os trabalhos $2^{,} 81$ comprovaram que o tratamento periodontal poderia melhorar o controle glicêmico.

Uma vez que um grande número de bactérias estaria diretamente relacionado à doença periodontal, muitas vezes, exames microbiológicos foram utilizados para os casos que respondiam mal à terapia mecânica tradicional, quando as leveduras poderiam ser encontradas entre os microorganismos detectados ${ }^{37}$.

Por sua vez, as leveduras têm sido associadas tanto a quadros patológicos quanto a saudáveis, em qualquer parte do corpo, incluindo a cavidade bucal, pois $40 \%$ da população adulta apresentavam Candida albicans na saliva e na mucosa bucal ${ }^{5}$, em 1980, que também acrescentaram que os quadros patológicos associados às infecções fúngicas estariam ligados a fatores locais e sistêmicos predisponentes ${ }^{50}$.

Entre os fatores locais ${ }^{5}$, os pacientes portadores de próteses totais, geralmente, apresentavam inflamação palatina causada por Candida albicans, sintomática ou assintomática, constituindo-se na infecção fúngica mais comum na cavidade bucal. Infelizmente, a associação 
entre leveduras e doença periodontal, têm recebido pouca atenção na literatura ${ }^{59}$. As leveduras são capazes de aderir e penetrar no epitélio, tão bem quanto causar uma reação inflamatória na mucosa e, consequentemente, ser danosa ao ambiente periodontal ${ }^{21}$. SLOTS; RAMS; LISTGARTEN ${ }^{71}$, em 1988, apud REYNAULD et al. ${ }^{59}$, em 2001, já comentavam sobre estudos que demonstravam a presença de leveduras nas bolsas periodontais, sugerindo um possível envolvimento destes organismos na patogênese da periodontite marginal. Da mesma forma, um tratamento citotóxico também estaria ligado a patogenicidade fúngica ${ }^{51,59}$, assim sendo, supôs-se que a antibioticoterapia favoreceria superinfecções por leveduras nas bolsas periodontais, resultantes da quebra da homeostasia da microbiota comensal. O mesmo foi relatado por RAMS; BABALOA; SLOTS 55, em 1990, que associaram este quadro aos antibióticos indicados por razões médicas.

Os aspectos emocionais e o estresse físico estariam em destaque entre os fatores gerais ${ }^{59,46}$, que abordaram que assim como a Candida albicans deveria ser considerada em pacientes imunocomprometidos, como é o caso dos diabéticos ${ }^{17}$, além dos microorganismos periodontopatogênicos ${ }^{14}$.

Embora se reconhecesse que a candidose bucal estivesse associada ao diabetes mellitus pobremente controlado e que a alta ocorrência de leveduras estivesse relacionada à periodontite imunocomprometida, não havia estudos ${ }^{84}$ que abordassem a relação entre a destruição periodontal e a ocorrência de microorganismos no periodonto diabético, bem como a Candida albicans deveria ser investigada por mais estudos in vitro e in vivo, quanto à possibilidade de se comportar como um patógeno para a periodontite do adulto e para a periodontite associada o diabetes, ainda como ela o faria, uma vez que as bolsas profundas propiciariam um bom reservatório para que a candidose bucal pudesse ocorrer. 
Considerando que: (a) o diabetes mellitus é uma doença crônica e atinge uma grande parcela da população, (b) suas complicações poderiam trazer grandes prejuízos sistêmicos aos diabéticos e conduzir a custos elevados para o indivíduo e para a sociedade, (c) o diabetes mellitus poderia ser agravado por microorganismos, entre eles as leveduras, (d) haveria comprovação da maior prevalência da doença periodontal nos diabéticos tipos 1 e 2, (e) o quadro periodontal no diabético tipo 1 se agrava com o tempo, podendo comprometer seu quadro sistêmico, estabelecer o perfil periodontal do paciente diabético tipo 1 e pesquisar a presença de leveduras nos sulcos gengivais é de vital importância para o controle glicêmico do paciente, uma vez que nos direcionaria a mecanismos periodontais preventivos, contribuindo para o controle metabólico do quadro diabético. 
2 REVISÃO DE LITERATURA 


\section{REVISÃO DE LITERATURA}

A revista da literatura será apresentada em tópicos, buscando esclarecer a inter-relação diabetes mellitus/ doença periodontal/ leveduras, proporcionando ao leitor a compreensão da relevância da investigação sobre a presença de leveduras no periodonto.

\subsection{Diabetes mellitus}

Em 2001, GALE ${ }^{25}$, em sua revisão, citou alguns fatos históricos que envolvem a classificação dos diabetes mellitus: Em 1866, um médico britânico, HARLEY ${ }^{28}$, comentou que havia duas formas distintas do diabetes mellitus, requerendo dois tratamentos distintos. Mais tarde, em 1880, um médico francês, denominado LANCEREAUX ${ }^{35}$, distinguia o diabetes magro do diabetes gordo. Nos anos 30, JOSLIN ${ }^{31}$ atribuiu a elevação da prevalência do diabetes ao aumento da obesidade. Em 1931, FALTA; BOLLER ${ }^{22}$, em Viena, observaram que havia dois tipos de diabetes: um sensível e outro resistente a insulina. DRAPER; DUPERTUIS; CAUGHEY ${ }^{19}$, em 1940, verificaram que havia dois tipos morfológicos, magro e gordo, de diabetes, sugerindo os termos provisórios de diabetes tipo 1 e 2, que permaneceram sem ser mencionados, até 1976, quando CUDWORTH ${ }^{13}$ voltou a introduzi-los. A base autoimune do diabetes mellitus tipo 1, foi reconhecida nos anos 70, aproximadamente entre 1974 e 1976.

Portanto, após ter sido dividido em dois tipos principais: tipo 1 ou tipo 2, anteriormente denominados, respectivamente, diabetes mellitus insulino-dependente e não-insulinodependente, a ASSOCIAÇÃo 
AMERICANA DE DIABETES 3, em 1997, propôs uma nova classificação, enfatizando que os tipos de diabetes não são dependentes da ingestão de insulina, mas sim se analisando a patologia envolvida, uma vez que tanto o tipo 1, como o tipo 2, poderia requerer tratamento insulínico em algum estágio da doença, vindo a acrescentar, além das acima citadas, o diabetes mellitus gestacional e outros tipos específicos.

Esta ASSOCIAÇÃO AMERICANA DE DIABETES 3 revisou os critérios diagnósticos do diabetes mellitus, embasando-se nos níveis elevados de glicose no sangue venoso quando: (a) os valores da glicose casual encontravam-se maiores ou iguais a $200 \mathrm{mg} / \mathrm{dl}$, ao serem obtidos a qualquer hora do dia, não importando o horário da refeição e estivessem associados aos sinais diabéticos (poliúria, polidipsia ou perda de peso), ou (b) a amostra de glicemia, em jejum (não ingestão de calorias pelos menos por oito horas) fosse maior ou igual a $126 \mathrm{mg} / \mathrm{dl}$, ou quando, c) as taxas glicêmicas fossem iguais ou superiores a $200 \mathrm{mg} / \mathrm{dl}, 2$ horas após ingestão de $75 \mathrm{~g}$ de glicose. Qualquer resultado positivo deveria ser confirmado através de um teste diferente do inicial, não sendo recomendável o teste de tolerância à glicose, como rotina.

Monitores de nível sanguíneo de glicose (glicosímetros), sempre que possível, eram usados pelos pacientes, como instrumentos próprios de monitoramento para diagnosticar o diabetes mellitus, ao contrário da avaliação dos níveis de glicose na urina usada por muitos anos, relatou ASSOCIAÇÃO AMERICANA DE PERIODONTOLOGIA ${ }^{4}$, em 2000.

REES ${ }^{57}$, em 2000, citou o teste de hemoglobina glicosilada como uma avaliação acurada, relativamente barata e sem a necessidade de abstinência alimentar, com níveis normais variáveis entre 5,0 e 7,5\%. De acordo com SOSKOLNE; KLINGER ${ }^{72}$, em 2001, este exame era utilizado para monitorizar os níveis séricos de glicose ao longo dos últimos 2 a 3 meses, através da medição dos níveis séricos de proteínas glicosiladas, 
especialmente a $\alpha$ - hemoglobina glicosilada ( $\mathrm{HbA} 1 \mathrm{c})$, que se incorporariam nas hemácias.

LALLA; D'AMBROSIO ${ }^{34}$, em 2001, fizeram uma revisão sucinta sobre a patofisiologia e as complicações do diabetes mellitus: os níveis glicêmicos normais encontram-se, ao longo do dia, entre 60 e 150 miligramas por decilitro, ou $\mathrm{mg} / \mathrm{dl}$, cujo equilíbrio é mediado pela insulina. A insulina promove a absorção da glucose pelas células e a estocagem dela no fígado, sob a forma de glicogênio; bem como, organizar os ácidos graxos e aminoácidos e sua, subsequente, conversão em triglicérides e proteínas. Com a deficiência de insulina no diabetes mellitus, as células não conseguem utilizar a glucose sanguínea, logo, as triglicérides são quebradas em ácidos graxos, como uma fonte alternativa de energia. Podendo conduzir a um acúmulo sangüíneo de cetonas, promovendo a cetoacidose. À medida que as taxas sanguíneas de glucose aumentam (hiperglicemia), a glucose é excretada pela urina, que passa a ser excessiva (poliúria), em decorrência da diurese osmótica. A perda líquida do organismo causa a uma desidratação, com consequente intensificação da sede (polidipsia). A deficiente absorção de glucose, ainda deprime o fluxo de energia para a célula, potencializando o apetite, no entanto, apesar deste esforço, a perda de peso acontece. Diante deste quadro, a incidência de complicações micro e macrovasculares aumentam, produzindo como sequelas a retinopatia, a nefropatia, a hipertensão, a hiperlipidemia, a aterosclerose, a doença vascular periférica e a doença cerebrovascular.

Para impedir complicações diabéticas, conforme TAYLOR 74, em 1999, buscava-se reduzir os níveis de glicose no sangue, empregando-se uma terapia insulínica agressiva e, caso não se obtivesse o resultado esperado, poderia ocorrer hipoglicemia severa ou choque decorrente do excesso de insulina.

Conforme LOPES; TRAMONTINA; MORITZ ${ }^{39}$, em 2001, a ocorrência do diabetes mellitus tipo 1, que compreende de 5 a $10 \%$ dos 
casos, seria devido a destruição das células pancreáticas beta de indivíduos geneticamente predispostos, que foram submetidos a determinadas condições, como uma infecção viral que induziu à uma destruição autoimune.

Por fim, neste ano de 2003, o Comitê Americano ${ }^{58}$ para o diagnóstico e classificação do diabetes mellitus a define como um grupo de doenças caracterizadas pela hiperglicemia, resultante de defeitos na secreção ou na ação da insulina, ou de ambos fatores. A hiperglicemia crônica do diabetes mellitus é associada a um dano a longo prazo ou a uma disfunção ou a uma falha de vários órgãos, especialmente os olhos, os rins, os nervos, o coração e vasos sanguíneos.

\subsection{Diabetes mellitus e Doença Periodontal}

Inúmeros trabalhos têm tido como meta estabelecer uma possível correlação entre diabetes mellitus e doença periodontal, no entanto, seus resultados têm se mostrado contraditórios.

O trabalho de COHEN et al. ${ }^{11}$, em 1970, apresentou dados coletados nos dois primeiros anos de um estudo longitudinal de cinco, cujas propostas eram estabelecer: (a) as diferenças quantitativas na progressão da doença periodontal, em diabéticos e não diabéticos femininos, (b) a significância longitudinal dos fatores locais, que poderiam iniciar, contribuir e/ ou modificar o progresso da doença periodontal nestes pacientes. Com isso, 21 diabéticos e 18 não diabéticos (18-35 anos) foram examinados, anualmente, por um médico, para avaliar o metabolismo de carboidratos e excluir a presença de outras doenças sistêmicas, bem como tiveram seu quadro periodontal investigado. Em cada exame periodontal, a diferença 
entre os grupos diabéticos e não diabéticos foi estatisticamente significante, mostrando um depósito de placa bacteriana menor, maior perda de inserção e maior escore gengival, nas pacientes diabéticas; enquanto que, não houve diferenças no acúmulo de cálculos, entre os dois grupos, havendo um aumento de perda de inserção, entre o $1^{\circ}$ e $\circ 3^{\circ}$ exame, de $38 \%$ nos diabéticos e $9 \%$ no outro grupo, embora não significante. Sugerindo, por fim, que isto seria reflexo da baixa resistência do grupo diabético.

Ao buscar determinar o efeito do diabetes mellitus na doença periodontal, BAY; AINAMO; GAD ${ }^{7}$, em 1974, evitaram medir a destruição periodontal ocorrida em diabéticos, a partir da avaliação da resposta gengival de 57 diabéticos controlados, com idade média de vinte anos, após uma semana da instituição de tratamento local, acompanhado de procedimentos de higiene bucal apropriados, comparando seus resultados com os de 49 pacientes não diabéticos. Constataram que, tanto os Índices de Placa, como o Índice Gengival, mostraram decréscimo significativo em ambos os grupos, sendo observadas diferenças na melhora da higiene entre os dois grupos, enquanto que, embora estatisticamente insignificantes, as condições gengivais apresentaram melhores resultados nos diabéticos, que nos não diabéticos. Os autores concluíram que não havia diferenças entre os dois grupos, quanto à condição gengival e sugeriram que o controle glicêmico poderia ser fator decisivo na inter-relação doença periodontal/ diabetes mellitus.

O quadro periodontal, de 263 crianças e adultos jovens diabéticos, foi avaliado por CIANCIOLA et al. ${ }^{10}$, em 1982, quanto à severidade e prevalência, sendo comparado com o quadro periodontal de uma população não diabética de 208 indivíduos. Consideraram que os índices que investigavam as condições periodontais, na época, poderiam estar subestimando ou mascarando a prevalência da doença periodontal localizada. Além do mais, estes índices não eram aplicáveis às dentições mistas, de pacientes jovens. Por outro lado, a perda de inserção medida pela profundidade de sondagem e a perda óssea avaliada pelas radiografias 
interproximais, poderiam estar superestimando a destruição periodontal. Baseados nestas considerações, os autores sugeriram novos critérios, para classificar a doença periodontal em indivíduos jovens, variando de gengiva normal à gengivite (leve, moderada e severa) e até a periodontite (leve, moderada e severa). Assim, observaram que 14 (9,8\%) dos 142 pacientes diabéticos insulino-dependentes, entre 11 e 18 anos e 2 pacientes $(1,7 \%)$, dos não diabéticos, apresentavam bolsas periodontais mais profundas e perda de inserção, com a periodontite ficando evidente, a partir de 12 anos de idade; já para aqueles diabéticos, com idade igual ou superior a 19 anos, a prevalência da periodontite chegou a $39 \%$, tendo ocorrido doença periodontal mais severa nos pacientes que apresentavam o diabetes mellitus por mais tempo. Portanto, este estudo concluiu que a doença periodontal é uma complicação do diabetes mellitus.

Quarenta e cinco pacientes diabéticos insulino-dependentes, com idade entre 10 e 18 anos e supervisionados por um endocrinologista pediátrico, foram divididos por BARNETT et al. ${ }^{6}$, em 1984, em 3 grupos etários $(10-12,13-15,16-18)$, com números equivalentes de homens e mulheres. A finalidade deste trabalho era estudar a prevalência da periodontite em pacientes diabéticos, com variação na duração do diabetes mellitus, bem como em seus níveis de controle. Sendo assim, realizaram-se a (1) história médica e bucal, o (2) exame de cabeça, pescoço e boca, o (3) índice gengival, o (4) índice de placa, bem como obtiveram as (5) radiografias interproximais posteriores e periapicais anteriores; por fim, solicitou-se o exame de hemoglobina glicosilada de 22 pacientes. Foram excluídos os dentes em erupção. Considerando (a) que a média dos índices de placa e gengival foram $0,65 \pm 0,37$ e 1,39 $\pm 0,22$, respectivamente; (b) que não foi observada correlação entre o índice gengival, com a idade e duração do diabetes mellitus, nem desta última com o índice de placa; (c) que não foram reveladas quaisquer correlações entre o grau de controle diabético e o índice gengival, índice de placa e duração do diabetes mellitus; (d) que não foram detectadas perdas ósseas interproximais, nem sinais 
radiográficos identificáveis de periodontite; pôde-se concluir que seria inapropriado generalizar, que os pacientes diabéticos insulino-dependentes jovens fossem mais susceptíveis à doença periodontal, principalmente em uma população estudada tão pequena.

Comparando as cáries e o estado periodontal de 169 pacientes diabéticos tipo 1 com idade média de 11,3 anos, variando de 5 a 18 anos, com sinais clínicos mínimos ou ausentes do diabetes mellitus e um grupo controle, cuja faixa etária média era 12 anos, GOTEINER et al. ${ }^{26}$, em 1986, verificaram que os escores de placa nos diabéticos eram estatisticamente maiores que no grupo controle, por outro lado, não houve diferenças quanto a perda de inserção e os índices CPOD e gengival, entre os dois grupos. Assim sendo, puderam concluir que o nível glicêmico estando controlado, não produziria resposta inflamatória exacerbada, em diabéticos jovens.

Buscando obter informações adicionais referentes ao estado periodontal de diabéticos, 46 adultos jovens portadores de diabetes mellitus tipo 1, por 10 anos ou mais, compreendendo entre 19 e 25 anos, foram comparados por RYLANDER et al. ${ }^{62}$, em 1986, com 41 controles saudáveis. O índice gengival, o nível de inserção clínica, a profundidade de sondagem, a recessão gengival e o levantamento radiográfico interproximal foram realizados, estabelecendo-se uma correlação fraca entre o controle metabólico, através dos níveis de hemoglobina glicosilada, e a frequência de unidades de gengiva inflamadas, enquanto não houve correlação entre os dados médicos e as variáveis periodontais. Encontraram-se similaridades entre os dois grupos, quanto ao nível de higiene, inflamação gengival, número de sítios com profundidade de sondagem maior que $3 \mathrm{~mm}$ e perdas ósseas interproximais; por outro lado, a frequência de sítios interproximais, com perdas de inserção maiores ou iguais a $2 \mathrm{~mm}$ e as recessões foram significativamente maiores no grupo diabético. Embora o índice de placa e o índice gengival tenham sido baixos, outro fator deveria ser analisado, para explicar a frequência de perda de inserção e a recessão gengival no grupo 
diabético, como técnica de escovação e hábitos individuais de higiene entre diabéticos.

Ao comparar dois grupos, 50 pacientes diabéticos e 53 pacientes controles, na mesma condição social, sexo e faixa etária, mínimo de 30 anos, TERVONEN; KNUUTTILA ${ }^{76}$, em 1986, visaram checar a falência periodontal entre ambas as populações citadas e estudar o efeito da manutenção dos níveis glicêmicos, sobre as condições periodontais. 0 grupo diabético foi subdividido em três grupos de indivíduos, bem controlados, os moderadamente controlados e os pobremente controlados, respectivamente em números de 10, 24 e 10. Os pacientes passaram por avaliação e tratamento médicos. A avaliação periodontal consistia em detectar cálculos supra e subgengivais e fatores de retenção de placa, bem como, avaliar o sangramento gengival, a profundidade de sondagem e o nível do osso alveolar, através de radiografias panorâmicas. Embora os pacientes diabéticos apresentassem porcentagem ligeiramente maior de bolsas periodontais, não houve diferenças estatisticamente significantes quanto à frequência delas, entre diabéticos e não diabéticos. A prevalência de bolsas foi similar entre o grupo controle e o grupo de pacientes diabéticos pobremente controlados, mas foi significativamente maior neste último grupo, em comparação aos diabéticos bem controlados. Variações no controle diabético não apresentaram influência estatisticamente significante sobre o nível do osso alveolar. Com isso, deduziu-se que o controle diabético conduziria a uma maior resistência do tecido conjuntivo periodontal e do osso alveolar.

ROSENTHAL; ABRAMS; KOPCZYK ${ }^{60}$, em 1988, verificaram a associação entre o estado periodontal de pacientes diabéticos insulino-dependentes e os parâmetros e complicações de sua doença. Cinquenta e dois pacientes, entre 11 e 22 anos, foram avaliados por um médico, quanto às complicações sistêmicas do diabetes mellitus e foram subdivididos em dois grupos: com e sem periodontite. Assim, a cavidade bucal foi inspecionada, buscando detectar qualquer lesão de mucosa; foram 
registrados o índice de placa, o índice gengival e o índice de sangramento sulcular; todas as bolsas superiores a $4 \mathrm{~mm}$ foram radiografadas, pelo método do cone longo, utilizando-se o aparelho Rinn XCP, tendo sido empregada uma régua milimetrada, para medir a distância da junção cemento esmalte à crista óssea. Os autores conferiram que a prevalência de periodontite, nos pacientes diabéticos insulino-dependentes, foi de 5,8\%. $\mathrm{O}$ índice gengival e $\mathrm{O}$ índice de sangramento sulcular foram significativamente maiores no grupo com periodontite, não demonstrando diferenças significativas em relação ao índice de placa, à idade de surgimento e duração do diabetes mellitus, à idade atual, a dose de insulina, as unidades de insulina por peso corporal ou a glicose sérica pós-prandial. A taxa de hemoglobina glicosilada foi significativamente menor no grupo com periodontite, enquanto a porcentagem de cetoacidose, complicações oftalmológicas e neurológicas foram maiores no grupo com periodontite. Os níveis do índice gengival foram maiores nos pacientes portadores de complicações neurológicas e outras infecções crônicas. Em relação às demais complicações, as diferenças não se apresentaram significativas, quando os grupos com e sem complicações foram comparados. Os autores sugeriram que a destruição periodontal poderia estar associada a um período anterior, quando não havia um eficiente controle glicêmico e concordaram com a hipótese de que a presença de periodontite pode ter colaborado para a dificuldade deste controle glicêmico.

Para analisar se o diabetes mellitus estaria associado ao maior risco de desenvolver a periodontite, HUGOSON et al. ${ }^{31}$, em 1989, compararam a prevalência e severidade da doença periodontal em três grupos de pacientes: diabéticos insulino-dependentes de curta e longa duração e não diabéticos, equiparados pela idade e sexo. Cento e cinquenta e quatro pacientes diabéticos e 77 não diabéticos responderam a um questionário e foram examinados clínica e radiograficamente, 154 diabéticos e 77 não diabéticos, que foram classificados de acordo com uma modificação dos critérios propostos por HUGOSON e JORDAN (1982). Não 
foram observadas diferenças significativas entre o diabetes mellitus de curta e longa duração, ainda entre os pacientes com diabetes mellitus com os não diabéticos, em relação ao número de dentes remanescentes, índice de placa, índice gengival, cálculos supra e subgengivais, por sextante e bolsas até $5 \mathrm{~mm}$; em contrapartida, detectou-se maior porcentagem de indivíduos com sítios iguais ou superiores a $6 \mathrm{~mm}$. Uma vez que detectaram um maior número de doença periodontal severa, na etária faixa de 40 - 49 anos, os autores consideraram a doença periodontal como uma possível complicação do diabetes mellitus de longa duração, reforçado pelo fato que desde o início da pesquisa houve mais mortes em pacientes com comprometimento periodontal severo e edêntulos do que naqueles com doença periodontal menos severa.

Por sua vez, SANDHOLM et al. ${ }^{64}$, em 1989, compararam 85 pacientes adolescentes diabéticos insulino-dependentes com 85 controles saudáveis, quanto ao índice de placa, índice gengival, índice de retenção de cálculo e avaliação radiográfica, onde foram realizadas 2 radiografias interproximais em todos os pacientes, mais 2 periapicais antero - superiores (dos dentes 12 ao 22) e antero - inferiores (dos dentes 32-42) nos diabéticos, visando (a) analisar as perdas ósseas, as taxas de hemoglobina glicosilada e de C-peptídeo e as complicações diabéticas, (b) determinar se os pacientes diabéticos deveriam ser considerados de risco para a doença periodontal. O grupo diabético foi subdividido, em relação a concentração de hemoglobina glicosilada (acima e abaixo de $8,5 \%$ ) e de acordo com as taxas de C-peptídeo (menor que $0,3 \mathrm{nmol}$ e maior ou igual a $0,3 \mathrm{nmol}$ ). Nos portadores de diabetes mellitus, os autores encontraram taxas normais de hemoglobina glicosilada com nível de bom para moderado, não havendo correlação com dados periodontais e duração do diabetes mellitus, secreção clínica de C-peptídeo significante em 3 pacientes, após o café da manhã, $5,9 \%$ de complicações, nenhuma perda óssea radiográfica superior a $1 \mathrm{~mm}$, bem como maior incidência de gengivite nos pacientes diabéticos do que nos pacientes controlados. Apesar dos pacientes diabéticos terem 
apresentado mais gengivite e maior número de superfícies com sangramento gengival não houve diferenças significativas entre este grupo e o grupo controle. Baseados em seus resultados, os autores sugeriram que uma terapia de manutenção deveria ser seguida, uma vez que toda a periodontite é precedida por uma gengivite.

Procurando (a) determinar a relação entre o grau de controle metabólico e a condição clínica periodontal, (b) determinar a presença de possíveis patógenos como Actinobacillus actinomicetemcomitans (Aa), bacteróides pigmentados sp e Capnocytophaga sp, em sítios periodontais saudáveis ou não, (c) determinar a influência do controle metabólico na microbiota subgengival periodontal, SASTROWIJOTO et al. ${ }^{65}$, em 1989, selecionaram 22 indivíduos diabéticos tipo 1, entre 18 e 60 anos, com pelo menos 1 sulco saudável (menor ou igual a $3 \mathrm{~mm}$, sem sangramento à sondagem calibrada após 30 segundos) e 1 bolsa periodontal (maior que $4 \mathrm{~mm}$, com sangramento à sondagem), sem história de antibioticoterapia e quimioterapia nos últimos 6 meses, desordens hemorrágicas e endócrinas, profilaxia antibiótica para endocardite, próteses e restaurações, próximas da gengiva ou subgengivais. Os pacientes se submeteram a avaliação médica (questionário completo de saúde, testes de função de rins e fígado, exames de anormalidades hematológicas) e exame da hemoglobina glicosilada, quando foram divididos em dois grupos (diabéticos próximos do controle metabólico, com taxas menores ou iguais a $7,7 \%$ e os diabéticos pobremente controlados, com taxas iguais ou superiores a 9,9\%). A avaliação periodontal compreendia o índice de placa, o índice de sangramento gengival e o índice de sangramento da bolsa periodontal e a profundidade de sondagem dos quadrantes. Seus resultados não evidenciaram diferenças significativas, entre os 2 grupos, diabéticos moderadamente e pobremente controlados, quanto aos índices periodontais nem no número de sítios saudáveis e doentes, nos quais as espécies foram detectadas. Quer fosse a idade do paciente diabético ou a duração do diabetes mellitus, não houve influências sobre a condição periodontal. A 
espécie Capnocytophaga foi isolada em níveis muito baixos em ambos os tipos de bolsas e em ambos os grupos. Embora não estatisticamente significante o Bacteróides gingivalis e Bacteróides intermedius foram isolados nos sítios doentes dos pacientes pobremente controlados, enquanto nos pacientes moderadamente controlados o Bacteroides intermedius apresentou uma maior porcentagem, embora ocorresse também nos sítios doentes; ainda em relação ao Bacteroide intermedius a diferença entre os sítios saudável e doente foi significativa. Concluiu-se que as condições periodontais entre os grupos não foram diferentes, mostrando que o controle metabólico não afeta diretamente o periodonto. A participação desta espécie Capnocytophaga na patogênese da doença periodontal em diabéticos foi superestimado. A participação do $\boldsymbol{A a}$ e das espécies Bacteroides pigmentadas são importantes na patogenia da doença periodontal de diabéticos, como o são em não diabéticos.

O trabalho de SAFKAN-SEPPÄLÄ; AINAMO ${ }^{63}$, em 1992, sugeriu que os indivíduos diabéticos insulino-dependentes pobremente controlados têm mais periodontite que aqueles com controle glicêmico relativo, ao comparar as condições periodontais de pacientes diabéticos tipo 1 de longa duração bem controlados, com a média das taxas de hemoglobina equivalente a $9,2 \%$, e pobremente controlados, com as médias das taxas de hemoglobina glicosilada igual a $10,7 \%$. Neste estudo, foram examinados 71 pacientes diabéticos insulino-dependentes com duração mínima de 10 anos, que foram classificados em bem controlados - em número de 44 indivíduos, com idade média de 42 anos - e pobremente controlados, 27 pacientes com idade média de 45 anos, que apresentavam maior nível de complicações diabéticas (retinopatia, nefropatia e neuropatia) e maiores níveis glicêmico e de hemoglobina glicosilada. Foram levantados: o índice de placa e o índice gengival, a perda de inserção, a profundidade de sondagem, a recessão gengival e a perda óssea, através de radiografias panorâmicas. Os pacientes diabéticos pobremente controlados apresentaram maior perda dentária que os pacientes diabéticos insulino- 
dependentes controlados, bem como, embora não significante, também apresentaram maiores perdas de inserção e osso alveolar.

Com a meta de comparar o estado periodontal da população com diabetes mellitus insulino-dependente, com duração e níveis diferentes da doença, e confirmar a eventual existência de uma manifestação precoce da periodontite em tais pacientes, DE POMMEREAU et al. ${ }^{18}$, em 1992, examinaram 85 pacientes adolescentes diabéticos, com idade estendendo de 12 a 18 anos, e compararam-nos com 38 indivíduos controles não diabéticos, na mesma faixa etária. O primeiro grupo foi dividido em pacientes com diabetes mellitus de curta duração, com menos que 6 anos de evolução, e pacientes com diabetes mellitus de longa duração, com 6 anos ou mais, correspondendo a $60 \%$ do total dos pacientes. A maturação sexual foi determinada pelo médico responsável, utilizando-se a classificação de Tanner. A hemoglobina glicosilada foi empregada para subdividi-los em: pacientes bem controlados (menor que $7 \%$ ), moderadamente controlado (entre $7-9 \%$ ) e pobremente controlado (maior que 9\%). O grupo consistia principalmente em diabéticos pobremente controlados (55\%). A condição periodontal foi avaliada baseada em índice de placa e índice gengival, no nível de inserção clínica e radiografias interproximais verticais para averiguar perdas ósseas maiores que $2 \mathrm{~mm}$. Depósitos visíveis de placa bacteriana foram observados em $32,2 \%$ das superfícies do grupo diabético e $28,5 \%$ dos pacientes não diabéticos. Não houve diferenças significativas entre 0 controle metabólico do diabetes mellitus e o índice de placa, embora $68,1 \%$ dos pacientes diabéticos pobremente controlados exibissem mais sítios, com placa bacteriana visível (mais que $25 \%$ das áreas), comparados com os $55,5 \%, 40,7 \%$ e $50 \%$ dos diabéticos bem controlados, moderadamente controlados e não diabéticos, respectivamente. Não foi significativa a diferença entre os índices de placa dos grupos de curta e longa duração, ou entre os vários índices de Tanner. Os diabéticos mostraram maior porcentagem de gengivite que os não diabéticos, onde o sangramento de sondagem ocorreu em $48 \%$ e $26 \%$ das superfícies sondadas, 
respectivamente. Não houve relação entre a condição gengival, o grau de controle metabólico, duração da doença e índice de Tanner. Ambos os grupos não mostraram diferenças significativas de perda de inserção. Assim, os autores concluíram que, embora a diferença da higiene entre os grupos não tenha sido significativa, os diabéticos insulino-dependentes mostraram frequência significativamente maior de gengivite, sendo que a porcentagem de sítios foi similar entre os diabéticos de curta e longa duração. Sendo os resultados contraditórios, não está claro que pacientes diabéticos insulinodependentes jovens sejam mais susceptíveis a doença periodontal, recomendando-se uma maior proservação periodontal destes pacientes.

SEPPÄLA; SEPPÄLA; AINAMO ${ }^{68}$, em 1993, a partir de um estudo de 2 anos, propuseram seguir longitudinalmente a condição periodontal em pacientes controlados ou pobremente controlados com diabetes mellitus de longa duração. Originalmente 38 portadores de diabetes insulino-dependentes de longa duração, na faixa etária 35 a 58 anos, com várias complicações diabéticas ao longo dos anos e após 1 ano, havia apenas 26 , restando 22 deles, dois anos após. Os pacientes foram divididos em pacientes diabéticos controlados e pacientes diabéticos pobremente controlados. Foram registrados o índice de placa, o índice gengival, e o índice de sangramento gengival, a perda de inserção, a perda óssea e a recessão gengival. Os pacientes que receberam instrução de higiene tiveram suas raízes raspadas e alisadas, sendo realizada cirurgia periodontal onde as bolsas excediam $6 \mathrm{~mm}$. Foi verificado que os níveis de glicemia e hemoglobina glicosilada foram maiores nos pacientes diabéticos pobremente controlados do que nos bem controlados, tanto no exame inicial como 1 ano após; ocorrendo a melhora da hemoglobina glicosilada apenas 2 anos após. $\mathrm{O}$ índice de placa era similar nos dois grupos no início do projeto e, após 1 ano, era maior nos pacientes diabéticos pobremente controlados. $O$ índice gengival e o índice de sangramento gengival foram maiores nos três exames dos pacientes diabéticos pobremente controlados de longa duração, que também mostraram mais perdas ósseas que os demais pacientes, as quais 
foram confirmadas por radiografias interproximais. Todos os pacientes diabéticos insulino-dependentes pobremente controlados exibiam mais recessões. Concluíram que não foram verificadas diferenças significativas entre a melhora do quadro periodontal e o nível de glicemia, tanto no $1^{\circ}$ como no $2^{\circ}$ exame, ainda verificaram que apesar dos níveis de placa serem similares em ambos os grupos, a perda óssea nos pacientes diabéticos insulino-dependentes pobremente controlado foi maior.

THORSTENSSON; HUGOSON ${ }^{78}$, em 1993, averiguaram que os pacientes diabéticos insulino-dependentes mais jovens tinham maior destruição periodontal que os não diabéticos na mesma idade, assim como a perda óssea era equivalente aquela dos mais velhos, quando procuraram analisar a doença periodontal em um grupo de pacientes com diabetes mellitus insulino-dependentes, de longa duração, na faixa etária de 40 a 70 anos, comparados com não diabéticos. Portanto, 83 pacientes diabéticos (12 com 40-49 anos, 22 com 50-59 anos, 49 com 60-69 anos) e 112 não diabéticos (14 com 40-49 anos, 27 com 50-59 anos e 71 com 60-69 anos), foram examinados clinicamente (registrando-se o índice de placa e o índice gengival, a profundidade de sondagem e o nível do osso alveolar) e radiograficamente. Verificou-se que havia número significante mais edêntulos entre os pacientes diabéticos insulino-dependentes que os não diabéticos, todos com idade não inferior a 50 anos. Os pacientes diabéticos insulino-dependentes entre 60-69 anos apresentaram maior porcentagem de sítios com placa bacteriana que os pacientes não diabéticos. Não houve diferenças significativas quanto à condição gengival entre os dois grupos. A frequência de bolsas até $5 \mathrm{~mm}$ não foi significativamente diferente entre os 2 grupos, enquanto os sítios com bolsas maiores ou iguais a $6 \mathrm{~mm}$, foram significativamente mais comuns nos diabéticos de 40-49 anos, evidenciado radiograficamente, onde $58,4 \%$ deles mostraram doença periodontal severa. Os autores consideraram que, uma vez que nos diabéticos a resistência tecidual estaria alterada e que muitos microorganismos periodontais 
poderiam suprimir o sistema imune, seria esperado que a associação destes dois fatores levaria a uma doença periodontal mais severa.

Em 1994, o trabalho de FIRATLI et al. ${ }^{23}$, teve a finalidade de investigar se havia relação entre o estado patológico do tecido gengival e a frutosamina plasmática, em crianças e adolescentes com diabetes insulinodependentes. Assim, 48 pacientes oito diabéticos insulino-dependentes e 20 pacientes saudáveis, foram examinados por um periodontista. Tendo sido registrado o índice de placa e índice gengival, a profundidade de sondagem e o nível de inserção clínica, com uma sonda periodontal de Williams e foram medidas a frutosamina sérica, a hemoglobina glicosilada e a glicemia. Os dados periodontais não apresentaram diferenças estatísticas significantes entre os dois grupos. Em contrapartida, os valores da frutosamina, a glicemia e a hemoglobina glicosilada média foram significativamente mais altos nos pacientes diabéticos. Houve uma correlação positiva entre os níveis de frutosamina e o índice gengival. Concluindo-se que a frutosamina e a gengivite estavam correlacionadas, sendo a gengivite mais prevalente nos diabéticos insulino-dependentes, pobremente controlados.

Para obter-se mais informação sobre a porcentagem de sítios, com progressão da doença periodontal, em pacientes diabéticos insulino-dependente controlados e diabéticos insulino-dependente pobremente controlados, SEPPÄLÄ; AINAMO ${ }^{68}$, em 1994, comparam os resultados do estudo longitudinal de 1 ano, com o acompanhamento sítio por sítio, observando-se que os tecidos gengivais responderam da mesma forma nos dois grupos, mostrando que o diabetes não impede uma resposta, a curto prazo, ao tratamento periodontal. Este mesmo tipo de avaliação confirmou os resultados anteriores, que sugerem que o diabetes mellitus insulino-dependentes pobremente controlados está fortemente relacionado à perda óssea. 
A proposta de PINSON et al. ${ }^{54}$, em 1995, foi determinar se havia diferenças entre o estado periodontal de uma população diabética e uma não diabética. Vinte e seis pacientes diabéticos tipo 1, com faixa etária compreendendo entre 7 e 18 anos, e 24 controles saudáveis foram avaliados clinicamente (índice de placa e índice gengival, profundidade de sondagem, nível de inserção clínica e índice de sangramento gengival, recessão gengival e fluxo do fluído gengival). Os diabéticos se submeteram ao exame de hemoglobina glicosilada. Para avaliar se os métodos eram duplicáveis, em 3 pacientes as medidas foram repetidas na mesma sessão. Embora não significativos, a média do nível de inserção clínica, profundidade de sondagem, índice de placa e índice gengival, recessão e fluído crevicular gengival foram maiores nos diabéticos; enquanto o sangramento à sondagem era maior nos não diabéticos. A duração média do diabetes mellitus era de 6,58. A hemoglobina glicosilada não foi estatisticamente significante, quando associada em nível de inserção clínica, profundidade de sondagem, índice gengival, recessão, fluxo gengival e sangramento à sondagem. O diabetes mellitus tipo 1 teve uma associação significativa com a severidade da doença periodontal e na inflamação gengival, quando sítios nos grupos de pacientes foram estatisticamente comparados. Por fim, não foi demonstrada nenhuma relação entre a severidade da doença periodontal e a duração do diabetes ou nível de controle.

ALDRIDGE et al. ${ }^{23}$, em 1995, concluíram em sua pesquisa que em pacientes diabéticos não pobremente controlados, a redução do quadro inflamatório não exerceu influência sobre o controle metabólico destes pacientes, pois não encontraram diferença estatística entre as taxas de hemoglobina glicosilada antes e após a terapia periodontal ter sido instituída.

Por um período de 5 anos, a frequência, de recorrência, da doença periodontal foi estudada por WESTFELT et al. ${ }^{81}$, em 1996. Verificouse que não houve a recorrência esperada, sugerindo que indivíduos diabéticos, que seguissem um programa rígido de controle de placa, 
reagiriam como os pacientes não diabéticos. No entanto, não desprezaram a o risco proporcionado pelo diabetes mellitus em desenvolver uma periodontite progressiva.

Com o objetivo de estudar a relação entre a eficácia da auto higiene e os níveis de hemoglobina glicosilada, SYRJÄLÄ; KNECKT; KNUUTTILA ${ }^{73}$, em 1999, avaliaram 149 pacientes diabéticos insulinodependente, através da aplicação de questionários e avaliação da placa bacteriana. Verificou-se que, naqueles indivíduos que apresentavam maiores níveis de orientação profissional, níveis de higiene melhores e maior frequência de consultas odontológicas, as taxas de hemoglobina glicosilada eram melhores, sugerindo a relevância da educação odontológica na compensação dos níveis glicêmicos.

A relação diabetes mellitus/doença periodontal foi discutida por SOSKOLNE; KLINGER ${ }^{72}$, em 2001, que relataram que não puderam identificar qualquer estudo, onde a prevalência do diabetes mellitus em pacientes portadores ou não de periodontite fosse analisada. Entretanto, os mesmos autores citaram o levantamento realizado pelo Departamento de Saúde e Serviços Humanos dos Estados Unidos, baseado nos dados do NHANES III (National Health and Nutrition Examination Survey), onde foram selecionados 1293 indivíduos com periodontite, $12,5 \%$ do total de 31.311 pacientes examinados. Seus resultados demonstraram que, entre os não portadores de periodontite, apenas $6,3 \%$ eram diabéticos, enquanto que entre os diabéticos, $17,3 \%$ apresentavam periodontite e, dos não diabéticos, apenas $9 \%$ o manifestaram. Assim sendo, a epidemiologia sugeria que havia evidências de que a periodontite seria mais prevalente em diabéticos e que a prevalência do diabetes mellitus em paciente com periodontite seria significantemente maior que aquela que ocorre nos indivíduos saudáveis.

TAYLOR ${ }^{75}$, em 2001, averiguaram que a terapêutica mecânica periodontal só melhorou o controle glicêmico quando associado à antibioticoterapia, especialmente a doxicilina. Sobre isto, tem sido sugerido 
que estes resultados se deveriam ao efeito antimicrobiano, à modulação do hospedeiro e, possivelmente à inibição do processo de glicosilação não enzimática.

\subsection{Leveduras e Doença Periodontal e Diabetes mellitus}

BIRMAN ${ }^{8}$, em 2002, historiaram a candidose, citando HIPÓCRATES (600 a. c.), que já descreveu a candidose (preferida pelo uso do sufixo OSE para fungos) ou candidíase pela primeira vez como aphthae albus ou albae. Da mesma maneira que GALENO (a D. 130) as denominou, quando foi observada sua maior frequência em crianças. Em 1700, a candidose vaginal foi investigada. Em 1839, estas lesões, até então denominadas aftas, passaram a ser associadas, etiologicamente, aos fungos, em um caso de tifo. Foi em lesões de boca que ocorreram as melhores descrições, por BERG em 1846. Finalmente, em 1923, BERKHOUT separou o gênero Candida do gênero Monilia.

Com as metas de determinar as taxas de $\boldsymbol{C}$. albicans em uma população dentada, de examinar as possíveis influências da idade, sexo, cárie, estado periodontal e fumo e de avaliar a distribuição intrabucal de C. albicans. ARENDORF; WALKER ${ }^{5}$, em 1980, selecionaram 54 indivíduos saudáveis, divididos por sexo (excluídos aqueles que apresentavam qualquer condição que favorecesse a instalação do fungo). Foi aplicando-lhes um questionário e realizado o exame clínico (avaliação quanto à presença candidoses na mucosa bucal, índice de cáries, índice da doença periodontal, índice de placa, temperatura sob a língua, $\mathrm{pH}$ da salivar sobre a superfície da língua), bem como, a coleta de saliva para culturas de Candida sp. As amostras salivares foram obtidas de moldagens, para analisar a distribuição da Candida em 10 sítios da mucosa bucal (jugal, 
sulco vestibular anterior, palato anterior e posterior, anterior e posterior do dorso lingual e comissuras labiais); através de compressão com esponja plástica estéril por 60 segundos, assim como de raspados celulares das regiões que sofreram a coleta por compressão. Por outro lado, embora a estatística não tenha sido significante, os fumantes apresentaram mais $\boldsymbol{C}$. albicans que os não fumantes, as mulheres eram mais prevalentes que os homens e a parte posterior da língua apresentou a maior incidência do fungo (83\%); verificaram também que a placa dental é colonizada secundariamente pela Candida albicans, após as demais áreas terem sido colonizadas. Desta forma, o portador de C. albicans foi identificado em $44,4 \%$ das áreas comprimidas, em $29,6 \%$ da saliva e $13 \%$ das moldagens, o que levou os autores a sugerirem que a técnica de compressão poderia ser utilizada para distinguir um portador de C. albicans, daquele que apresentasse a lesão de $\boldsymbol{C}$. albicans; enquanto que não evidenciaram influência dos demais dados sobre a $\boldsymbol{C}$. albicans.

FISHER et al. ${ }^{24}$, em 1987, tiveram o intuito de determinar a importância relativa do controle glicêmico, estado dentário e regimes de tratamento (insulínico, agentes hipoglicemiantes e dieta) sobre frequência e quantidade de portadores de Candida spp. na cavidade bucal de pacientes diabéticos. A partir disto, classificaram 412 diabéticos quanto ao tipo de tratamento médico instituído para o diabetes mellitus e quanto a condição de serem ou não portadores de prótese total removível (parcial ou total). A avaliação do controle glicêmico foi obtida, pela manhã, através do exame de hemoglobina glicosilada e do uso de glicosímetro. Foi coletada uma amostra da saliva através da técnica de bochecho e semeada em placas de Sabouraud dextrose agar, incubadas a $37^{\circ}$ por 48 horas. A contagem de colônias foi realizada com o aparelho Gallenkamp e o número de colônias por milímetro foi quantificado. As leveduras foram isoladas e identificadas pela produção do tubo germinativo, pela assimilação de açúcar e padrões de fermentação. Verificou-se que não houve correlação entre a Candida e o controle glicêmico, estabelecido pela taxa de hemoglobina glicosilada. O tipo 
e frequência de Candida foram similares nos três grupos de tratamento médico. A espécie mais freqüente isolada foi a $\boldsymbol{C}$. albicans, enquanto $\boldsymbol{C}$. tropicalis e $\boldsymbol{C}$. glabrata eram as mais frequentes dentre as outras espécies. A contagem de Candida spp. foi maior nos portadores de prótese total do que nos pacientes que estavam sob tratamento insulínico ou com hipoglicemiantes orais. Concluiu-se que os pacientes diabéticos, portadores de dentadura, apresentaram maior quantidade de colônias que os dentados, bem como o controle glicêmico não afetou a população de Candida bucal em pacientes diabéticos.

SLOTS; RAMS; LISTGARTEN ${ }^{71}$, em 1988, apud REYNAULD ${ }^{59}$, em 2001, relataram uma prevalência de $16,8 \%$ de leveduras nas bolsas periodontais consideradas refratárias a tratamentos mecânicos convencionais, entretanto muitos haviam recebido antibioticoterapia prévia à amostragem.

No estudo prospectivo de SASTROWIJOTO et al. ${ }^{66}$, em 1990, buscou-se averiguar se as mudanças no controle metabólico estariam associadas às mudanças no estado periodontal clínico, da mesma forma que na microflora subgengival de sítios periodontais saudáveis e doentes, de pacientes diabéticos insulino-dependentes. Para isto, 9 pacientes diabéticos insulino-dependentes pobremente controlados, com taxa de hemoglobina glicosilada acima de $10 \%$, foram examinados pelo médico, empregando-se um questionário completo de saúde; tendo sido obtidos exames laboratoriais hematológicos e de creatinina, de ureia e de enzimas hepáticas, cujos resultados estavam normais. Após 7 dias de ingresso no projeto, coletaramse os primeiros dados periodontais, após os quais, o paciente se submetia a um controle insulínico convencional intensivo. Tendo decorrido nove meses do início da pesquisa, os pacientes diabéticos foram examinados a cada quatro meses, quanto ao seu estado metabólico, sua condição periodontal clínica (índice de placa, índice de sangramento gengival e a profundidade de sondagem) e aspectos microbiológicos subgengivais. Nenhuma medida de higiene foi instituída, a não ser aquela que o paciente já fazia, antes deste 
estudo. Os efeitos de um melhor controle metabólico a longo prazo refletiram em uma queda significante das taxas de hemoglobina glicosilada e do

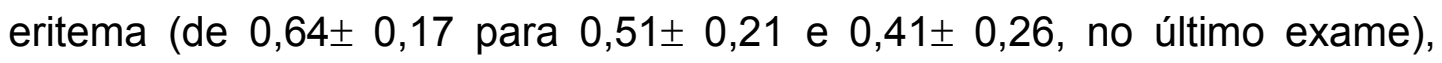
enquanto nos demais dados coletados não se evidenciou diferenças significativas. Em geral, também não houve diferenças significativas na flora bacteriana, sendo que em dois pacientes foi encontrada C. albicans, embora não frequentemente, somente nos sítios periodontais doentes. Os autores concluíram que o controle metabólico melhorado não teve efeito potencial sobre a condição periodontal clínica, que apenas melhoraria com a instituição de medidas de higiene bucal.

Baseados no fato que os antibióticos sistêmicos poderiam causar supercrescimento de bastonetes entéricos facultativos gramnegativos, leveduras e estafilococos em várias localidades do corpo, RAMS; BABALOLA; SLOTS ${ }^{55}$, em 1990, avaliaram as alterações a curto prazo das espécies subgengivais de Enterobactérias, Candida e Staphilococcus, associadas a terapia sistêmica de periodontite adulta com doxiciclina por 21 dias, amplamente utilizada em periodontia. Foi estudado um total de 21 adultos (11 homens e 10 mulheres, na faixa etária de 32 a 66 anos), com periodontite avançada, foi estudado. Todos os pacientes estavam em bom estado sistêmico e não haviam recebido terapia antibiótica nos 6 meses anteriores. A todos foram fornecidas instruções de higiene bucal e de 4 a 6 horas de sessões de raspagem periodontal e alisamento radicular. O sítio periodontal mais profundo em cada quadrante dentário foi definido para amostragem microbiana; amostras também foram coletadas da região palatina anterior e dorso da língua. Os sítios periodontais foram avaliados antes e depois da terapia com doxiciclina sistêmica, através dos índices de placa e gengival e da profundidade de sondagem. Após o regime com doxiciclina, foi verificado que de 10 a $15 \%$ dos pacientes experimentaram aumento substancial de bastonetes entéricos ou de leveduras e $50 \%$ dos pacientes manifestaram elevação do número de estafilococos subgengivais. Cinco pacientes apresentaram leveduras subgengivais, em pequeno 
número, após o debridamento mecânico e, após terapia sistêmica com doxiclina, 2 destes pacientes exibiram um aumento de 10 vezes e enquanto os outros 3 permaneceram essencialmente inalterados. Em pequeno número, foram encontradas leveduras, na língua e palato, de 2 pacientes, antes da terapia sistêmica com doxiclina, enquanto 7 pacientes apresentavam-na, depois do mesmo tratamento. Todas as leveduras isoladas pertenciam à espécie $\boldsymbol{C}$. albicans. Este estudo demonstrou que terapia sistêmica com doxiciclina poderia favorecer o supercrescimento de bastonetes entéricos, leveduras e estafilococos na microflora subgengival de pacientes adultos com periodontite. Mesmo que o supercrescimento detectado no estudo fosse transitório, poderia causar colonização prolongada ou "permanente", pela superinfecção de organismos. Caso isto ocorresse, estes microorganismos poderiam evitar a resolução de patologias periodontais e, até, propiciar o agravamento contribuindo para colapsos periodontais. Os autores sugeriram que estas hipóteses ainda deveriam ser testadas.

Objetivando avaliar a ocorrência subgengival de pseudomonas, leveduras e estafilococos, em relação à idade e ao sexo, SLOTS; FEIK; RAMS ${ }^{70}$, em 1990, selecionaram 3075 pacientes, com faixa etária variando de 12 a 93 anos que apesar de terem se submetido a várias formas de tratamento periodontal, incluindo antibioticoterapia (com exceção dos últimos dois meses), apresentava aprofundamento das bolsas, com evidências radiográficas de perdas ósseas (mínimo de $6 \mathrm{~mm}$ ) em pelo menos três dentes. Amostras subgengivais destes três sítios foram coletadas e avaliadas microbiologicamente. Dentre os pacientes, $60 \%$ eram mulheres e $47,3 \%$, delas, apresentavam os microorganismos estudados, em comparação aos $43,9 \%$ dos homens. Apesar de que, os cocos e as pseudomonas tenham sido isolados em $13,6 \%$ dos sujeitos examinados. Staphilococcus apareciam duas vezes mais do que os outros microorganismos. Embora não tenha havido associação entre a sua ocorrência com o sexo, as leveduras subgengivais foram detectadas em 
$14 \%$ das mulheres e $13 \%$ dos homens, constituindo proporções muito pequenas da microflora subgengival. Segundo os autores, a presença da levedura subgengival poderia ser uma superinfecção, resultante da extensão delas a partir de outras superfícies bucais, tal o fato delas estarem em baixos níveis subgengivais, sugeria serem colonizações transitórias, contrastando com a natureza insidiosa dos fungos em outras áreas da boca. Este trabalho não explicou o porquê $10 \%$ das mulheres teriam apresentado mais fungos que os homens, levantando duas hipóteses ou haveria uma maior susceptibilidade ou teriam recebido mais terapias, fato que teria favorecido a superinfecção. Concluiu-se que, os altos níveis dos cocos entéricos e pseudomonas subgengivais em alguns indivíduos, poderiam ser importantes na patogênese da periodontite em idosos e de outras formas de periodontite, podendo ter implicações terapêuticas.

$\mathrm{Na}$ investigação de RAMS; SLOTS ${ }^{54}$, em 1991, sobre a distribuição de biótipos de Candida em sítios subgengivais, 55 pacientes com periodontite severa, com faixa etária entre 22 e 65, sem sinais clínicos de candidíase forneceram amostras subgengivais cujos resultados foram comparados com dados publicados. A C. albicans correspondeu $81,8 \%$ das amostras, com 11 biotipos. Em pequenas proporções (média de $0,9 \%$ ) a $\boldsymbol{C}$. parapsilosis foi isolada, tendo apresentado dois biotipos. Um único biotipo de $\boldsymbol{C}$. tropicalis e outro, de uma Candida não identificada, também foram isolados. Por fim, os autores questionaram se a distribuição da C. albicans, na periodontite de pacientes imunosuprimidos, seria similar àquela da periodontite do adulto.

Ao avaliarem a relação entre a taxa salivar de glicose e a colonização bucal de Candida, DARWAZEH et al. ${ }^{16}$, em 1991, compararam 41 pacientes diabéticos e 34 pacientes saudáveis. A concentração salivar de glicose, nos pacientes diabéticos, foi significativamente maior e, diretamente, relacionada a concentração sanguínea de glicose. Embora, a concentração de Candida não mostrasse diferença significativa, entre os dois grupos de pacientes, evidenciou-se que, a concentração de glicose era 
maior nos pacientes onde a Candida foi identificada, do que naqueles pacientes que não apresentavam esta levedura.

Em 1993, HESTER et al. ${ }^{30}$, compararam as taxas de Candida spp. em 56 indivíduos, sendo que, 28 deles eram HIV positivos e 28 pacientes eram saudáveis. As diferenças não foram significativas entre eles, uma vez que $68 \%$ dos indivíduos saudáveis e $75 \%$ dos pacientes HIV positivos apresentaram a Candida. A C. albicans compreendeu 95\% de todas as espécies isoladas. Um ano após, RUHNKE et al. ${ }^{30}$. Puderam identificar a C. albicans em $66 \%$, a C. glabrata em $16,5 \%$ e a C. Krusei em $12 \%$ das amostras colhidas de 65 pacientes aidéticos.

No estudo de THORSTENSSON; DAHLÉN; HUGOSON ${ }^{77}$, em 1995, foram verificadas, na microflora subgengival, as espécies bacterianas, Actinobacillus actinomycetemcomitans, Campylobacter rectus, Capnocytophaga sp, Eikenella corrodens, Fusobacterium nucleatum, Porphyromonas gingivalis e Prevotella intermedia, tanto em pacientes diabéticos, quanto em não diabéticos, bem como mostraram títulos séricos de anticorpos, para a maioria dos antígenos, similares em ambos os grupos. O $\boldsymbol{P}$. gingivalis foi detectado mais vezes em pacientes diabéticos, mais velhos e apenas nas bolsas periodontais. Assim, os autores sugeriram que, outros fatores, como a susceptibilidade do hospedeiro, poderiam ser importantes para o desenvolvimento da doença periodontal.

O objetivo do estudo de DAHLÉN; WIKSTRÖM ${ }^{15}$, em 1995 , foi avaliar a ocorrência de cocos entéricos, estafilococos e leveduras nas amostras subgengivais de lesões periodontais avançadas submetidas ao monitoramento microbiológico. Quinhentos e trinta e cinco pacientes finlandeses com periodontite e com perda recorrente de inserção periodontal, submetidos a várias formas de tratamento periodontal e alguns sem ter recebido qualquer terapia, participaram com 973 amostras de sítios com periodontite progressiva ou de sítios com sangramento persistente. Cocos entéricos, estafilococos e/ ou fungos foram encontrados em $65,6 \%$ 
das amostras de $76,7 \%$ dos pacientes. Os fungos se constituíram a menor parte da flora, compreendendo $7,3 \%$ das amostras de $19,6 \%$ dos pacientes. Assim, os autores concluíram que, em finlandeses, com periodontite, a frequência de microorganismos não bucais, foi baixa, mas sugeriram que, em altas concentrações, poderiam produzir e manter infecções significativas na mucosa, incluindo a gengivite.

$\mathrm{Na}$ cavidade bucal, sob mudanças imunológicas ou locais, as amostras bucais de Candida podem se tornar patogênicas, com invasão tecidual, assim, tanto as micoses do trato digestivo como as do trato respiratório podem se disseminar, segundo MONTEIL; MADINIER; FICHOUX ${ }^{47}$, em 1997, o que de acordo com BIRMAN 30, em 2002, podiam produzir infecções em diversas localizações do corpo humano. Esta mesma autora comentou que a candidose não é tão comum na população em geral, apesar de ser encontrada em grande porcentagem da população, requerendo predisposição individual e atuação de fatores predisponentes sistêmicas e locais.

Também, de acordo com BIRMAN ${ }^{8}$, em 2002, o gênero Candida destacou-se entre as várias leveduras presentes na cavidade bucal, podendo ser encontradas como comensais, em cerca de 40 a $60 \%$ dos indivíduos sadios. Com mais de 150 espécies, dos quais 50 manifestam no homem e, destas, 17 estão associadas a doenças, sendo a Candida albicans a mais frequente entre todas as espécies.

Vários fatores sistêmicos predispõem ao desenvolvimento da candidose bucal, incluindo imunodeficiências (AIDS), desordens endócrinas (diabetes), doenças malignas, discrasias sanguíneas severas (agranulocitose), radioterapia e muitas drogas (antidepressivos, antibacterianos, esteróides e quimioterápicos). Entre os fatores locais de risco estão a xerostomia, o uso de prótese total, fumo intenso e higiene bucal deficiente, relataram MONTEIL; MADINIER; FICHOUX ${ }^{47}$, em 1997. 
Também denominada "boca seca", a xerostomia, ou até os quadros de diminuição do fluxo salivar (hipossalivação) induziriam a uma maior proliferação de fungos, favorecendo uma maior prevalência da doença, considerando que os constituintes salivares colaborariam para a manutenção do $\mathrm{pH}$, na proteção dos tecidos moles e duros da boca, disse BIRMAN ${ }^{8}$, em 2002.

Segundo MONTEIL; MADINIER; FICHOUX ${ }^{47}$, em 1997, o diagnóstico provisório é baseado nos aspectos clínicos da candidose, que se apresentam de formas variadas, conforme BIRMAN ${ }^{8}$, em 2002: (a) pseudomembranosa (agudo) (b) eritematosa (aguda e crônica), (c) hiperplásica, (d) queilite angular e a (e) mucocutânea.

Para os mesmos autores ${ }^{47}$, em 1997. O tratamento inclui a eliminação do fator local de risco, a melhora da higiene bucal e uso de antifúngicos tópicos e, em imunocomprometidos, utilizaram antifúngicos sistêmicos.

Ao selecionarem 72 pacientes (29 homens, com idade média de 56 anos e 43 mulheres, com idade média de 62 anos), dos quais 14\% eram pacientes diabéticos, MONTEIL; MADINIER; FICHOUX ${ }^{47}$, em 1997, tinham como meta avaliar a resistência, in vitro, à antifúngicos, da $C$. albicans de pacientes HIV negativos, com lesão clínica de candidose, ou apenas com a cultura positiva para leveduras. A coleta foi feita com swabs a partir das lesões, ou das superfícies sob as próteses totais removíveis e imediatamente semeadas, em meio Sabouraud com cloranfenicol, a $30^{\circ} \mathrm{C}$, por 3 a 7 dias. A partir daí, foram testados a anfofericina $B$, a fluorocitocina, o econazol, o citoconazol, o miconazol e o fluconazol. Em 93\% dos casos, as culturas revelaram C. albicans, isoladas ou associadas, $5 \%$ de Torulopsis glabrata, C. Krusei em 1\% e Geotrichum candidum em 3\%. A resistência in vitro da Candida foi obtida em 64 amostras, com diferentes níveis de resistência. A conclusão dos autores foi que a Candida albicans era amplamente dominante na cavidade bucal; tendo sido rara a associação 
de múltiplas leveduras apresentando resistência a muitos dos antifúngicos testados, sendo que mesmo nos pacientes que haviam tomado antifúngico recentemente, ou não sabiam, $36 \%$ da $\boldsymbol{C}$. albicans mostrou resistência in vitro ao fluconazol, não sendo verificada resistência aos polienos. Portanto, este estudo confirmou que seria útil empregar um teste padrão de susceptibilidade, associado a um antifungigrama para o diagnóstico micológico, quando se suspeitasse de candidose bucal e se planejasse usar um derivado azóico como antifúngico.

Considerando as escassas informações sobre o padrão de colonização uniclonal ou policlonal da C. albicans, MATA et al. ${ }^{41}$, em 2000, selecionaram um grupo de 11 crianças, com faixa etária entre 8 e 10 anos, saudáveis, não estando sob qualquer terapia medicamentosa e forneceram amostras salivares, não estimuladas, que resultaram em 110 colônias fúngicas, das quais 49 foram identificadas como C. albicans, buscando investigar se haveria ao mesmo tempo biotipos diferentes de $\boldsymbol{C}$. albicans na boca. Observaram-se muitos locus heterozigoto de $\boldsymbol{C}$. albicans e que apenas $45 \%$ das crianças apresentaram colonização monoclonal. Os autores concluíram que poderia haver mais que um tipo genético de $\boldsymbol{C}$. albicans em cavidades bucais de crianças, com colonização multiclonal.

Com o intuito de determinar a presença de Candida dubliniesis na cavidade bucal e se esta estaria associada a lesões, 414 pacientes diabéticos tipo 1 , que não receberam antibioticoterapia ou corticoterapia, nos últimos 3 meses, foram selecionados por WILLIS et al. ${ }^{82}$, em 2000. Através da técnica de bochecho com $10 \mathrm{ml}$ de solução salina estéril tamponada com fosfato, verificou-se que 318 dos pacientes diabéticos (77\%) apresentavam Candida spp.; a C. albicans foi a espécie mais freqüente (201/318), seguida pela C.dubliniensis (58/318) e C. glabrata (11/ 318); entre os pacientes portadores de $\boldsymbol{C}$. dublinenses, 6(10\%) apresentavam-na como único fungo, em 11 pacientes diabéticos (19\%) estava associada a outras espécies Candida e tinham evidências clínicas de infecção, enquanto, nos pacientes com características de 
normalidade, 7 (12\%) deles, apresentavam somente a C. dubliniensis e em 34 pacientes $(59 \%)$ a $\boldsymbol{C}$. dubliniensis estava associada a outras espécies de Candida.

O estudo de COSTA et al. ${ }^{12}$, em 2001, teve o objetivo de realizar uma análise epidemiológica da presença de leveduras em lesões da cavidade bucal, dos pacientes da clínica de semiologia da faculdade de odontologia de Ribeirão Preto, da Universidade de São Paulo. Através de técnicas rotineiras de isolamento e identificação foram caracterizados vários microrganismos, entre os quais C. albicans, que esteve presente em $56,25 \%$ dos casos de infecções por leveduras, seguidos por $43,75 \%$ de outras Candida sp.

No estudo de YUAN et al. $^{84}$, em 2001, 105 pacientes diabéticos não insulino-dependentes, que não tinham ingerido antibióticos nos últimos 3 meses, e 141 não diabéticos foram comparados, em relação à flora subgengival, utilizando-se a técnica da reação em cadeia da polimerase (PCR). Os dados periodontais coletados com uma sonda periodontal de Williams, consistiam de índices de placa e gengival, do nível de inserção clínica e da profundidade de sondagem. As amostras foram coletadas de um sítio doente e um sítio saudável; o primeiro se caracterizava por apresentar a maior profundidade de sondagem, superior a $3 \mathrm{~mm}$ e que tivesse o maior valor do nível de inserção clínica, entre todos os sítios examinados e, no caso em que não houve sítio superior a $3 \mathrm{~mm}$, foi selecionado o local com maior índice gengival, ou seja, aquele que apresentou inflamação gengival mais severa; enquanto que o sítio sadio correspondia à área com profundidade de sondagem inferior a $3 \mathrm{~mm}$ e com menor valor de nível de inserção Os resultados mostraram que as diferenças entre diabéticos e não diabéticos, quanto aos índices de placa e gengival, a profundidade de sondagem e o nível de inserção clínica, foram insignificantes. As taxas de Candida albicans, encontradas nos sítios saudáveis e doentes dos não diabéticos, foram, respectivamente, $15,6 \%$ e 29,8\%, já nos diabéticos foram verificados $18,1 \%$ nos sítios saudáveis e $35,3 \%$ nos doentes, superior 
aqueles $13 \%$ encontrados nos pacientes portadores de periodontite associada ao HIV, estudados por MOORE et al. ${ }^{48}$, em 1993. Evidenciou-se que o padrão de distribuição da $\boldsymbol{C}$. albicans similar aos outros 4 patógenos estudados (A. actinomycetemcomitans, $P$. gingivalis, $T$. dentícola e $E$. corrodens), pois tanto nos sítios doentes como nos saudáveis não houve diferenças significativas. Os autores consideraram como possíveis justificativas para estes resultados: (a) a limitação da PCR ao distinguir quantidades pequenas ou grandes do mesmo patógeno, (b) que não haveria diferenças na ação dos periodontopatógenos, quer fosse na periodontite do adulto, como na periodontite diabética, (c) deveria haver outros microorganismos que estariam associados a esses tipos de periodontite e que não foram avaliados neste estudo; também, foi colocado que uma vez que estes patógenos periodontais exerciam o mesmo o papel em ambas as periodontites, não deveria haver diferenças na prevalência delas.

O objetivo do estudo de REYNAULD et al. ${ }^{59}$, em 2001, era investigar a prevalência de leveduras nas bolsas periodontais, de pacientes com periodontite e estudar possíveis associações entre as leveduras, a condição clínica dos sítios amostrados e os periodontopatógenos bacterianos presentes. Os pacientes foram divididos em dois grupos: (a) 128 pacientes (79 mulheres e 49 homens, com idade variando entre 16 a 85 anos) tratados; enquanto que em outro grupo (b) havia 126 pacientes requerendo tratamento periodontal sistemático (pelo menos com 4 dentes com bolsas de $4 \mathrm{~mm}$ ou mais). O sinal de inflamação era baseado no sangramento à sondagem. $\mathrm{O}$ sexo e a idade eram registrados, enquanto que a anamnese era realizada quando havia testes positivos para fungos. Amostras foram coletadas no segundo grupo em dois sítios mais comprometidos, para cultivo e identificação. Encontrou-se uma prevalência de leveduras no grupo (a) de $15,6 \%$ e no grupo (b) de $17,5 \%$, embora não fossem encontradas em todas as amostras do mesmo paciente. Observouse uma correlação fraca entre as leveduras nas bolsas periodontais e 
Eubacterium saburrem. Segundo os autores, as leveduras corresponderam ao quinto microorganismo mais comumente isolado.

O objetivo do trabalho de HANNULA et al. ${ }^{27}$, em 2001, foi estudar a relação entre os subtipos de $C$. albicans com a localização geográfica e a ecologia subgengival, de acordo com a coexistência de várias bactérias periodontopatogênicas. A $\boldsymbol{C}$. albicans foi isolada de um total de 60 pacientes provenientes da Finlândia, EUA e Turquia, que contribuíram com 5 amostras isoladas de $\boldsymbol{C}$. albicans. As amostras subgengivais foram coletadas dos sítios periodontais mais inflamados, caracterizados por sangramento gengival e perda da inserção periodontal clínica e/ ou radiográfica, através de uma cureta na Finlândia e com pontas de papel nos EUA e Turquia; em seguida, as amostras foram semeadas e cultivadas em meio para $\boldsymbol{C}$. albicans e bactéria periodontal. As $\boldsymbol{C}$. albicans confirmadas foram sorotipadas em A, com aglutinação, e B, sem aglutinação, e genotipadas empregando-se a reação em cadeia da polimerase(PCR).Os resultados mostraram que existem diferenças geográficas na distribuição subgengival dos sorotipos e genótipos de C.albicans; bem como, onde a $\boldsymbol{C}$. albicans era positiva havia menor número de espécies bacterianas, sugerindo que fossem realizadas novas análises dos fatores ambientais, que pudessem favorecer a colonização e a persistência subgengivais da $\boldsymbol{C}$. albicans.

A prevalência e a variabilidade genotípica das leveduras na cavidade bucal de pacientes diabéticos tipo 1 e 2 foram abordados por MANFREDI et al. ${ }^{40}$, em 2002, investigando-se as amostras coletadas de 58 pacientes diabéticos tipo 1 e de 81 pacientes diabéticos tipo 2, através de bochechos bucais. Foram isoladas espécies de Candida. Em 83 pacientes (60\%), não tendo ocorrido diferenças estatisticamente significantes entre os tipos diabéticos e o número de pacientes portadores de Candida, bem como, a presença e a distribuição genotípica da $\boldsymbol{C}$. albicans não foi influenciada pelo tipo ou duração do diabetes mellitus, nem pelas taxas de hemoglobina glicosilada ou pelas complicações diabéticas. Os diabéticos 
dentados apresentaram estatisticamente menos leveduras que os pacientes controles; enquanto nos diabéticos portadores de prótese total, foram evidenciadas outras espécies de Candida, que não eram albicans. As outras espécies Candida predominantes foram consecutivamente a $\boldsymbol{C}$. glabrata em 10 indivíduos, a C. krusei em 3 indivíduos, a C. parapsilosis em 2 indivíduos, a $\boldsymbol{C}$. guillermondi em 2 indivíduos e 1 indivíduo com $\boldsymbol{C}$. tropicallis e outro com C. Iusitaniae. Por fim, os autores sugeriram que não puderam constatar nenhuma associação entre C. albicans e o tipo, a progressão e o grau de controle do diabetes mellitus, bem como, a flora fúngica não seria única nos pacientes diabéticos. 
3 PROPOSICEÃO 


\section{PROPOSIÇÃO}

Baseado nas colocações expostas pela literatura, este estudo teve como metas:

1. Analisar as condições periodontais e da mucosa de pacientes diabéticos tipo 1, com maior e menor tempo de evolução;

2. Identificar e qualificar a presença de leveduras no sulco gengival e na saliva dos pacientes diabéticos tipo 1 e nos controles;

3. Inter-relacionar a presença de leveduras e o controle glicêmico do paciente. 
4 MATERIAL E MÉTODOS 


\section{MATERIAL E MÉTODOS}

\subsection{Seleção dos Pacientes}

Com a finalidade de averiguar a presença de leveduras no sulco gengival de pacientes diabéticos insulino-dependentes esta pesquisa foi realizada nos primeiros 24 pacientes voluntários, de ambos os sexos, inscritos no projeto consecutivamente, que foram divididos em três grupos: diabéticos tipo 1 ou insulino-dependentes, nas faixas etárias de 10 a 19 anos (GRUPO A) e 20 anos ou mais (GRUPO B), selecionados entre os membros da Associação de Diabéticos de Apucarana (ADIAP) e da Clínica Cervantes de endocrinologia, não importando a presença ou não de doença periodontal, e um grupo controle (GRUPO C) constituído por pacientes não diabéticos, que tiveram seu quadro glicêmico normal comprovado pela glicemia, com 20 anos ou mais, portadores de doença periodontal em níveis variados, encaminhados por cirurgiões - dentistas da Associação Odontológica de Apucarana. Os pacientes diabéticos estavam sob controle médico periódico. Os critérios de exclusão compreenderam aqueles com história prévia de antibioticoterapia por 6 meses, fumantes, que estivessem sob tratamento ortodôntico ou apresentassem outras doenças imunossupressoras, ou seja, qualquer outro fator que pudesse favorecer o acúmulo de placa e, consequentemente, da doença periodontal, bem como a proliferação da levedura em questão. 


\subsection{Comitê de Ética em Pesquisa e Instruções Gerais aos Pacientes}

Após avaliação e aprovação do projeto pelo Comitê de ética em Pesquisa da Faculdade de Odontologia de Bauru, da Universidade de São Paulo, uma reunião com pacientes e/ ou responsáveis legais foi realizada com o objetivo de apresentar e explicar os métodos e metas do projeto; da mesma forma, foi enfatizada a importância de responderem corretamente a todo questionamento que Ihes fosse aplicado, bem como os benefícios que os participantes obteriam com sua participação neste estudo e a repercussão que as conclusões deste trabalho poderiam trazer a toda população diabética. Neste mesmo momento foram lidas, explicadas e assinadas as cartas de informação, como também os termos de consentimento legal e esclarecido.

\subsection{Exame clínico e Exame Periodontal}

Posteriormente, em todos os grupos, executou-se a anamnese acompanhada do exame físico, compreendendo a inspeção das mucosas, da oclusão, dos dentes e o exame periodontal, sendo que todos os procedimentos foram realizados pelo mesmo examinador que, por razões de cuidados que os pacientes exigiam, sabia quais eram diabéticos, no entanto desconhecia os resultados microbiológicos até o final do projeto.

A avaliação periodontal constituiu-se de: (a) índice de placa (Silness; Löe ${ }^{69}, 1964$ ), (b) profundidade de sondagem, (c) índice de 
sangramento gengival (Ainamo; Bay 1, 1975), (d) índice gengival (Löe ${ }^{38}$, 1963) e (e) nível de inserção clínica.

O Índice De Placa (IP) (Silness; Löe ${ }^{69}$, 1964), importante em estudos longitudinais e transversais clínicos, baseava-se na avaliação da espessura da placa e não de sua extensão coronal, bem como não desprezavam as superfícies restauradas ou que apresentassem próteses subgengivais. Os critérios variavam de 0 a 3, onde o primeiro corresponderia à ausência de placa bacteriana e o último, a presença abundante desta placa na margem cervical e/ou superfície adjacente do dente. Entre estes dois extremos encontravam-se o índice 1, caracterizado pela detecção da placa bacteriana, ao raspar a superfície dentária com a sonda, e o índice 2 , quando a placa podia ser visualizada a olho nu, na margem gengival e/ou na superfície adjacente do dente.

O Índice Gengival (IG) (Lö $\left.\mathrm{e}^{38}, 1967\right)$ determinava a prevalência e a gravidade da inflamação, tanto em estudos epidemiológicos como em individuais. No IG o escore gengival $\mathbf{0}$ correspondia a uma gengiva saudável, o 1 a uma inflamação leve (pequena alteração de cor e pouco edema, sem nenhum sangramento), o 2 a uma inflamação moderada (rubor, edema, superfície brilhante e sangramento à sondagem) e o 3 a uma inflamação aguda (rubor intenso, edema, ulceração e tendência ao sangramento espontâneo).

O Índice De Sangramento Gengival (ISG) (Ainamo; Bay 1, 1975) foi empregado para detectar presença ou ausência de sangramento, ocorrido até 10 segundos após a sondagem do sulco gengival, visando avaliar a evolução do paciente quanto à melhora ou piora do estado inflamatório, podendo ser correlacionado ao índice de placa e índice gengival, refletindo-se em porcentagem diante de um total de margens gengivais avaliadas. 
O diagnóstico de periodontite é geralmente feito baseado nas medidas de profundidade de sondagem e Nível de Inserção Clínica, de acordo com SOLKONE; KLINGER ${ }^{72}$, em 2001.

A Profundidade de Sondagem (PS) compreendeu a medida da distância da margem gengival ao fundo da bolsa ou sulco gengival, enquanto os valores do Nível de Inserção Clínica (NIC) se referiram à distância entre a junção amelo-cementária e a margem gengival. Ambos os registros (Profundidade de Sondagem e Nível De Inserção Clínica) foram medidos em milímetros e eram obtidos com sondas periodontais milimetradas* Hu-friedy PC PUNC 15, tomando-se o cuidado para controlar a pressão e o maior paralelismo com o longo eixo do dente, em 6 áreas de cada um de todos os dentes (mesio, disto-vestibular, centro da face vestibular, mesio, disto-lingual e centro da face lingual).

A periodontite foi diagnosticada clinicamente, quando se detectou perda óssea em dois ou mais sítios. Com o intuito de diagnosticar a periodontite radiograficamente, empregou-se tomadas radiográficas padronizadas periapicais (dentes anteriores superiores e inferiores, em número de 6), utilizando-se os posicionadores Rinn XCP* (RINN CORPORATION - USA), pela técnica do paralelismo e tomadas radiográficas posteriores, pela técnica interproximal com a película na posição horizontal (quando necessário de pré-molares e molares separadamente). Tendo sido considerado como normal quando a distância da junção amelo-cementária à crista óssea não excedeu 2-3mm, medida através de uma régua milimetrada, conforme a técnica de DUNNING; LEACH ${ }^{20}$, em 1960, comprovando a existência de periodontite diante de perdas ósseas interproximais em dois ou mais dentes, segundo CIANCCIOLA et al. ${ }^{10}$, em 1982.

Avaliação Do Fluxo Salivar: O grau de secreção salivar foi avaliado pelo teste de fluxo salivar recomendado por NAVARRO; CÔRTES 49, em 1995, é expresso em mililítros por minuto. As referências para a 
análise de tais condições foram contadas como normais (de 1,0 a 3,0 ml/ minuto), ou com fluxo salivar baixo (0,7 a $1,0 \mathrm{ml} / \mathrm{minuto})$, ou com hipossalivação (menos de 0,7 ml/ minuto).

\subsection{Exame Microbiológico}

O material para o exame microbiológico foi obtido de dois sulcos gengivais interproximais, um saudável e outro comprometido pela doença periodontal. Também foi coletada uma amostra de saliva, em tubo esterilizado, após teste do fluxo salivar. O sulco saudável correspondeu àquele que apresentou ausência de inflamação com escores 0 de índice gengival, seguidos, prioritariamente, por menores profundidades de sondagem, índice de sangramento gengival e índice de placa; tendo ocorrido características similares em dois sítios ou mais, o local selecionado foi aquele mais para mesial, ou seja, com maior facilidade de controle de placa; por outro lado, o sulco comprometido foi considerado aquele que apresentava características inflamatórias mais intensas, com maior profundidade de sondagem e, uma vez havendo sítios semelhantes, escolheu-se os maiores níveis quantitativos de índice gengival, de índice de sangramento e de índice de placa, sequencialmente.

Após remoção da placa e cálculo supra gengival com cureta Gracey estéreis, seguida de lavagem com a água destilada, secagem com leve jato de ar e isolamento relativo com rolos de algodão, também estéreis, auxiliado por sugador convencional, prevenindo-se a contaminação salivar, procedeu-se a amostragem subgengival. A coleta foi realizada infiltrando-se um cone de papel absorvente endodôntico esterilizado, número 40, estéril, por 10 segundos em cada sítio. Em seguida, a semeadura foi executada, assepticamente, em placas de Petri contendo Sabouraud dextrose ágar 
(SDA), acrescido de $100 \mu \mathrm{g} / \mathrm{ml}$ de cloranfenicol. As placas semeadas foram incubadas em estufa a $30^{\circ} \mathrm{C}$ por 5 dias, sendo que aquelas que não apresentaram crescimento permaneceram por mais 5 dias, permitindo a realização da contagem de colônias.

Após desenvolvimento, as colônias foram analisadas conforme as características macromorfológicos: cor, tamanho, consistência, superfície, bordos, brilho e topografia das colônias. As colônias selecionadas foram confirmadas através das propriedades morfotintoriais avaliadas pela coloração de Gram. Aquelas enquadradas como leveduras foram repicadas para tubos de ensaio contendo (SDA), incubadas a $25^{\circ} \mathrm{C}$ e armazenadas para posterior identificação, outra amostra de cada uma dessas colônias foram mantidas em água destilada estéril, para a necessidade de se repetir a análise microbiológica. A identificação em nível de gênero e espécie foi feita conforme a metodologia prevista pela Sociedade Americana de Microbiologia, descrita por LARONE ${ }^{36}$, em 1995.

Os pacientes diabéticos foram periodicamente avaliados pelo endocrinologista, através do exame de hemoglobina glicosilada, cujos valores entre 5,0 e 7,5\%, portanto dentro da faixa de normalidade, segundo SOLSKONE;KLINGER ${ }^{72}$, em 2001, foram considerados como bem controlados; estando os valores superiores a $11 \%$, taxa mais elevada citada na literatura pesquisada, fornecida por ROSENTHAL; ABRAMS; KOPCZYK ${ }^{60}$, em 1988, indicava-se um pobre controle diabético e enquanto estivessem entre os níveis descritos (7,5\% e $11 \%$ ) foram classificados como moderadamente controlados; sendo que o resultado de um exame prévio, mas mais próximo, ao atendimento odontológico do paciente, foi utilizado como referência nesta pesquisa. 


\subsection{Análise Estatística}

Em todas as tabelas, que demonstravam os quadros periodontais dos pacientes, foram expressos os valores médios dos índices periodontais e seus desvios padrões.

As condições periodontais, dos 3 grupos amostrados, foram comparadas pelo teste não paramétrico de Kruskal-Wallis by Ranks e, uma vez, tendo sido encontradas diferenças estatísticas significantes $(p<0,05)$, foi aplicado teste de Dunn para comparações múltiplas.

Nas comparações, entre os quadros periodontais dos pacientes diabéticos, moderadamente e pobremente controlados, foi empregado o teste de Mann-Whitney, enquanto, nas comparações dos quadros periodontais, dos pacientes portadores ou não de leveduras, utilizou-se o teste do qui-quadrado.

A presença de lesões de mucosa foi expressa por estatística descritiva de pacientes portadores; tendo sido empregado o teste do quiquadrado, nas comparações de sua frequência, entre diabético e não diabéticos e dentre os pacientes pobremente e moderadamente controlados.

A presença de leveduras foi descrita por número e/ou frequência de sítios acometidos e por número e/ou frequência de indivíduos, com pelo menos 1 sítio infectado. Foi utilizado o teste do qui-quadrado, para as comparações da frequência de leveduras por grupo de pacientes estudados e entre os sítios amostrados, bem como o Teste Exato de Fisher, na comparação dos resultados positivos para leveduras nos sulcos gengivais entre pacientes diabéticos e controles. 
As comparações, entre os pacientes pobremente e moderadamente controlados, em relação a sua distribuição por grupo estudado ( $A$ e $B$ ), também foram executadas pelo teste do qui-quadrado. 
5 RESULTADOS 


\section{RESULTADOS}

Enquanto o grupo controle foi composto por 4 mulheres e 4 homens e entre os pacientes diabéticos, nossa casuística foi representada por $75 \%$ dos indivíduos do grupo A pertencentes ao sexo feminino, bem como $50 \%$ dos indivíduos do grupo B. O tempo de evolução do diabetes mellitus compreendeu de 18 a 144 meses (média de 82,12 meses) nos pacientes do grupo A e, entre 48 e 276 meses (média de 175,5 meses), nos pacientes do grupo $B$, sendo que a história familiar de diabetes mellitus foi observada em $87,50 \%$ dos pacientes. Na TABELA 1 e FIGURA 1, as principais características desta amostra são apresentadas.

TABELA 1 - Perfil das amostras.

\begin{tabular}{lcccc}
\hline GRUPOS & MULHERES & HOMENS & $\begin{array}{c}\text { IDADE } \\
\text { MÉDIA }\end{array}$ & DURAÇÃO MÉDIA \\
\hline A & $75 \%(6)$ & $25 \%(2)$ & 14,7 anos & 82,1 meses \\
B & $50 \%(4)$ & $50 \%(4)$ & 29,5 anos & 175,5 meses \\
C & $50 \%(4)$ & $50 \%(4)$ & 25,0 anos & -- \\
Total de pacientes & 14 & 10 & --- & -- \\
\hline
\end{tabular}

$A=$ diabéticos do grupo $1 ; B=$ diabéticos do grupo $2 ; C=$ grupo controle. 


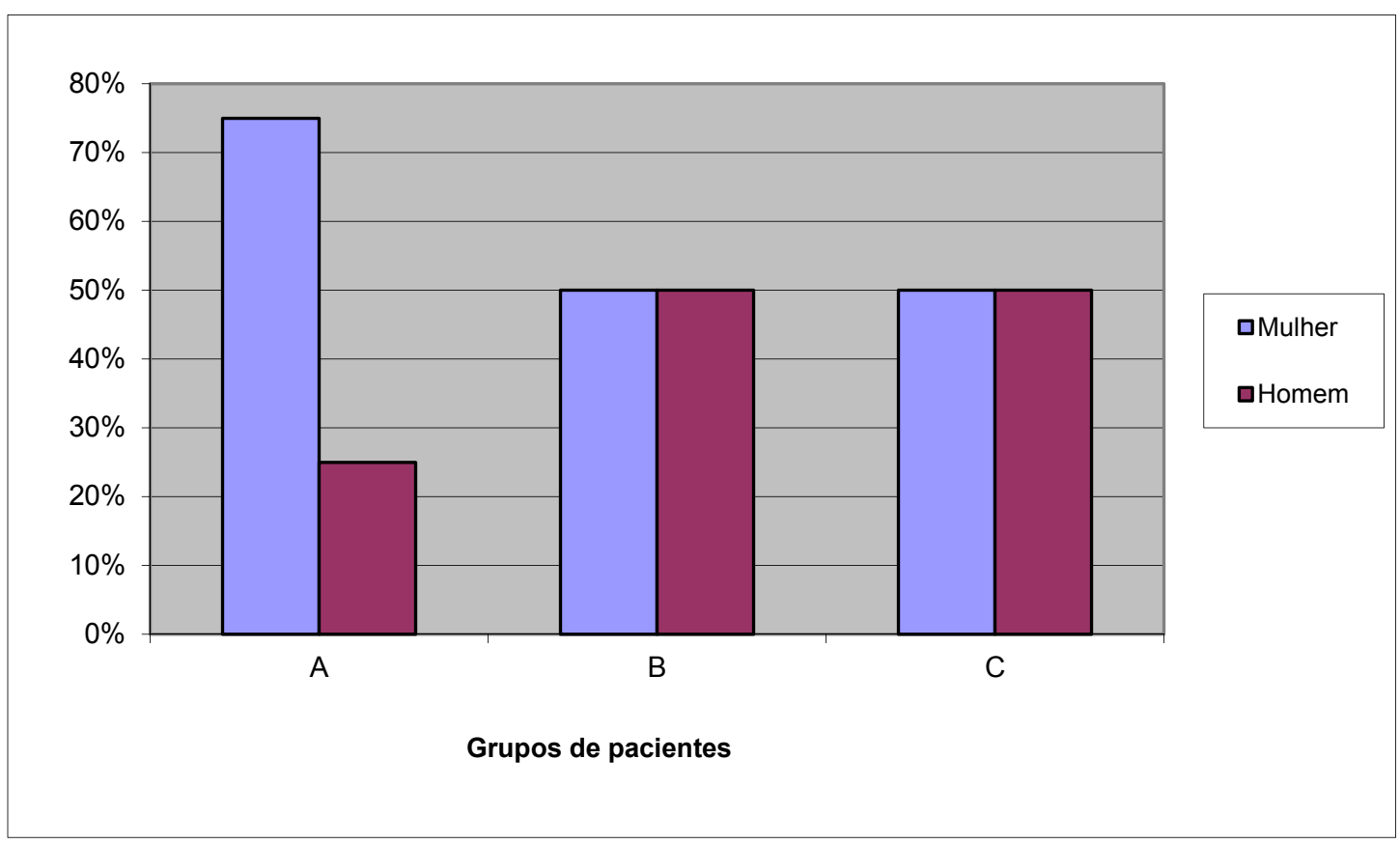

FIGURA 1 - Gráfico ilustrativo do perfil das amostras estudadas

Clinicamente, não foram identificados sinais ou sintomas que sugerissem presença de candidose bucal, mas sim foram detectados outros tipos de alterações morfológicas na mucosa Entre os pacientes diabéticos, 10 pacientes apresentavam alterações (5 indivíduos do grupo A e 5 indivíduos do grupo B): 2 pacientes com úlceras traumáticas, 3 pacientes com mucosa mordiscada (mais comuns) 1 paciente com nevus branco esponjoso associado à mucosa mordiscada, 1 paciente com língua geográfica, 1 paciente com líquen plano reticular, 1 paciente com mancha metálica e 1 paciente com hipótese de neoplasia benigna (lipoma). Dos pacientes não diabéticos (grupo C), 4 (50\%) apresentaram lesões, dentre elas: 1 paciente com mucosa mordiscada, 1 paciente com língua geográfica, 1 paciente com grânulos de Fordyce e 1 paciente com afta.

A TABELA 2 e FIGURA 2 apresentam a distribuição por grupo pesquisado dos pacientes que manifestaram lesões da mucosa bucal, não existiram diferenças estatisticamente significantes $(p=0,842)$ nos três grupos avaliados, segundo o Teste do Qui - quadrado $(\chi \cdot 2=0,343)$. 
Verificou-se que os dois grupos diabéticos exibiram o mesmo número de pacientes portadores de lesões de mucosa bucal; o grupo controle, por sua vez, mostrou equivalência entre os indivíduos com e sem lesões de mucosa bucal.

TABELA 2 - Frequência de lesões da mucosa bucal distribuídas nos grupos pesquisados.

\begin{tabular}{|c|c|c|c|}
\hline \multirow{2}{*}{$\begin{array}{l}\text { Grupo de } \\
\text { pacientes }\end{array}$} & \multicolumn{2}{|c|}{ LESÕES DE MUCOSA } & \multirow[t]{2}{*}{ Total } \\
\hline & Presentes & Ausentes & \\
\hline $\mathbf{A}$ & $5(62,50 \%)$ & $3(37,50 \%)$ & 8 \\
\hline B & $5(62,50 \%)$ & $3(37,50 \%)$ & 8 \\
\hline C & $4(50,00 \%)$ & $4(50,00 \%)$ & 8 \\
\hline Total & 14 & 10 & 24 \\
\hline
\end{tabular}

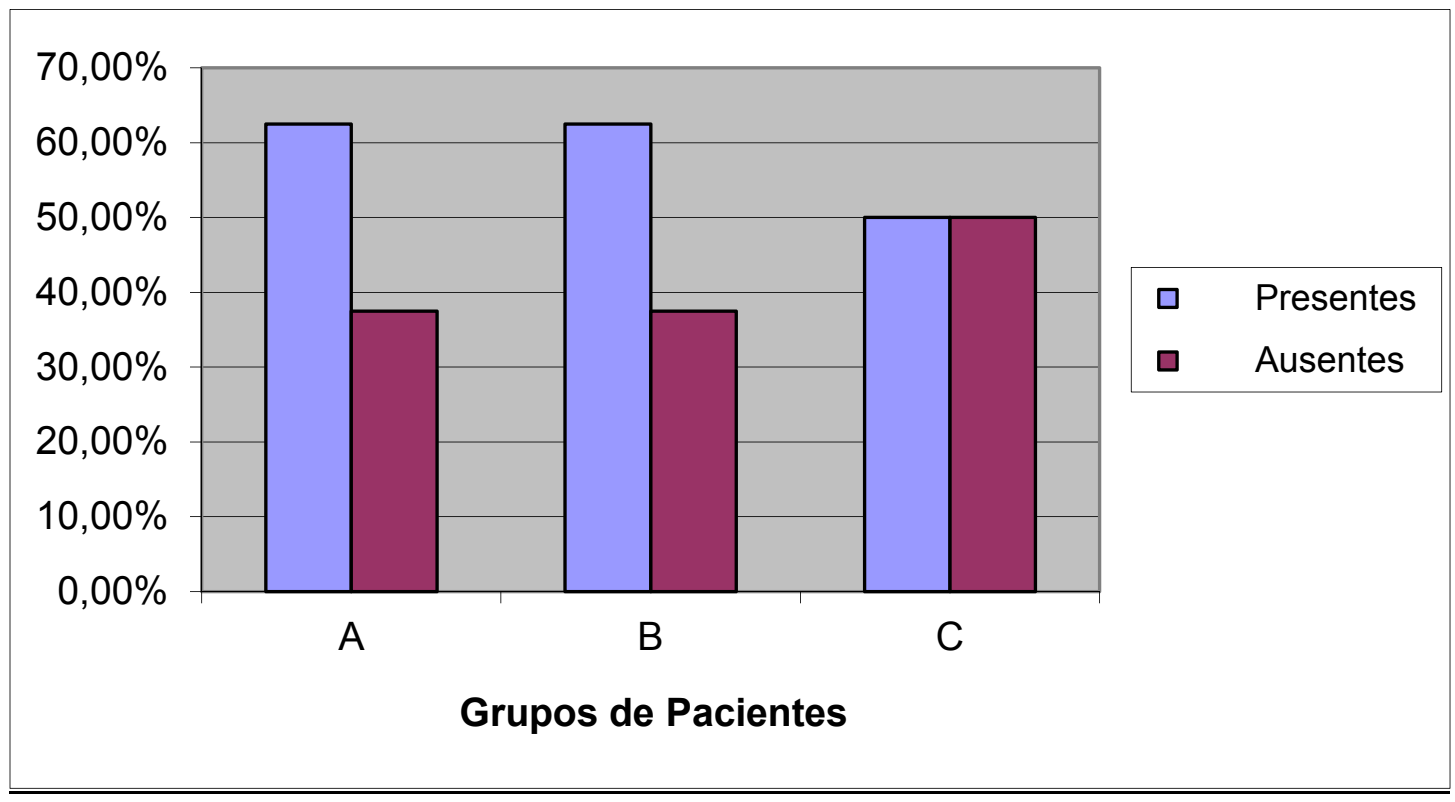

FIGURA 2 - Gráfico ilustrativo da frequência de lesões da mucosa bucal distribuídas nos grupos de pacientes pesquisados. 
Os valores médios e respectivos desvios padrões dos dados colhidos na avaliação periodontal de cada grupo pesquisado são mostrados na TABELA 3 e nas FIGURAS 3, 4 e 5, constando o índice de placa (IP), o índice gengival (IG) e o índice de sangramento gengival (ISG), o nível de inserção clínica (NIC) e a frequência da profundidade de sondagem de sítios até $3 \mathrm{~mm}$, de sítios de 4 a $5 \mathrm{~mm}$ e de sítios com $6 \mathrm{~mm}$ ou mais.

TABELA 3 - Valores médios $(x)$ e desvio padrão (dp) dos índices periodontais clínicos de pacientes dos grupos diabéticos tipo 1 ( $A$ e $B$ ) e dos pacientes controles $(\mathrm{C})$.

\begin{tabular}{|c|c|c|c|c|}
\hline \multirow{3}{*}{$\begin{array}{c}\text { INDICES } \\
\text { PERIODONTAIS } \\
\text { CLÍNICOS }\end{array}$} & \multicolumn{3}{|c|}{ GRUPOS DE PACIENTES } & \multirow{3}{*}{$\begin{array}{c}\text { Teste de } \\
\text { Kruskall } \\
\text { Wallis } \\
\text { P }\end{array}$} \\
\hline & $A$ & $B$ & $\mathrm{C}$ & \\
\hline & $x \quad d p$ & $\begin{array}{ll}\mathrm{X} & \mathrm{dp}\end{array}$ & $\begin{array}{ll}\mathrm{x} & \mathrm{dp}\end{array}$ & \\
\hline IP & $1,24 \pm 0,30$ & $1,65 \pm 0,73$ & $1,99 \pm 0,39$ & $0,0171^{*}$ \\
\hline IG & $1,48 \pm 0,19$ & $1,48 \pm 0,37$ & $1,76 \pm 0,36$ & 0,1012 * \\
\hline ISG \% & $35,41 \pm 17,03$ & $50,20 \pm 30,1$ & $64,60 \pm 10,77$ & 0,0389 * \\
\hline $\mathrm{NIC}(\mathrm{mm})$ & $0,36 \pm 0,22$ & $1,56 \pm 1,43$ & $1,17 \pm 0,81$ & 0,0084 * \\
\hline PS -3mm (\%) & $97,35 \pm 1,94$ & $83,06 \pm 26,45$ & $80,62 \pm 7,92$ & 0,0067 * \\
\hline PS -4-5mm (\%) & $2,49 \pm 1,81$ & $11,29 \pm 16,81$ & $18,06 \pm 12,43$ & 0,0081 * \\
\hline PS -6mm (\%) & $0,14 \pm 0,27$ & $5,63 \pm 7,41$ & $1,30 \pm 1,31$ & 0,1561 \\
\hline \multicolumn{5}{|c|}{$\begin{array}{l}\text { - IP= Índice de placa; IG= Índice gengival; ISG= Índice de sangramento gengival; NIC= } \\
\text { nível de inserção clínica; PS= Profundidade de sondagem. }\end{array}$} \\
\hline \multicolumn{5}{|c|}{ * diferença estatística significante $(p \leq 0,05)$} \\
\hline
\end{tabular}




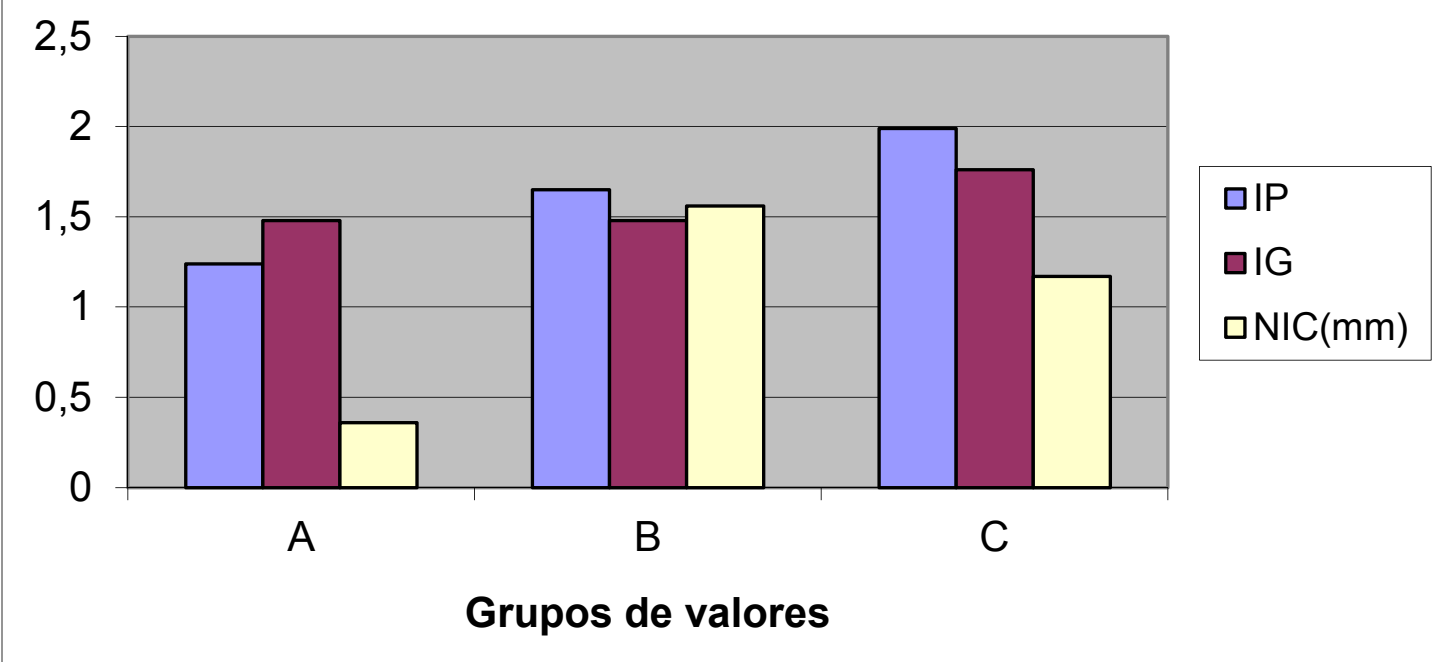

FIGURA 3 - Gráfico representativo dos valores médios do índice de placa. Índice gengival e nível de inserção clínica dos grupos de pacientes estudados.

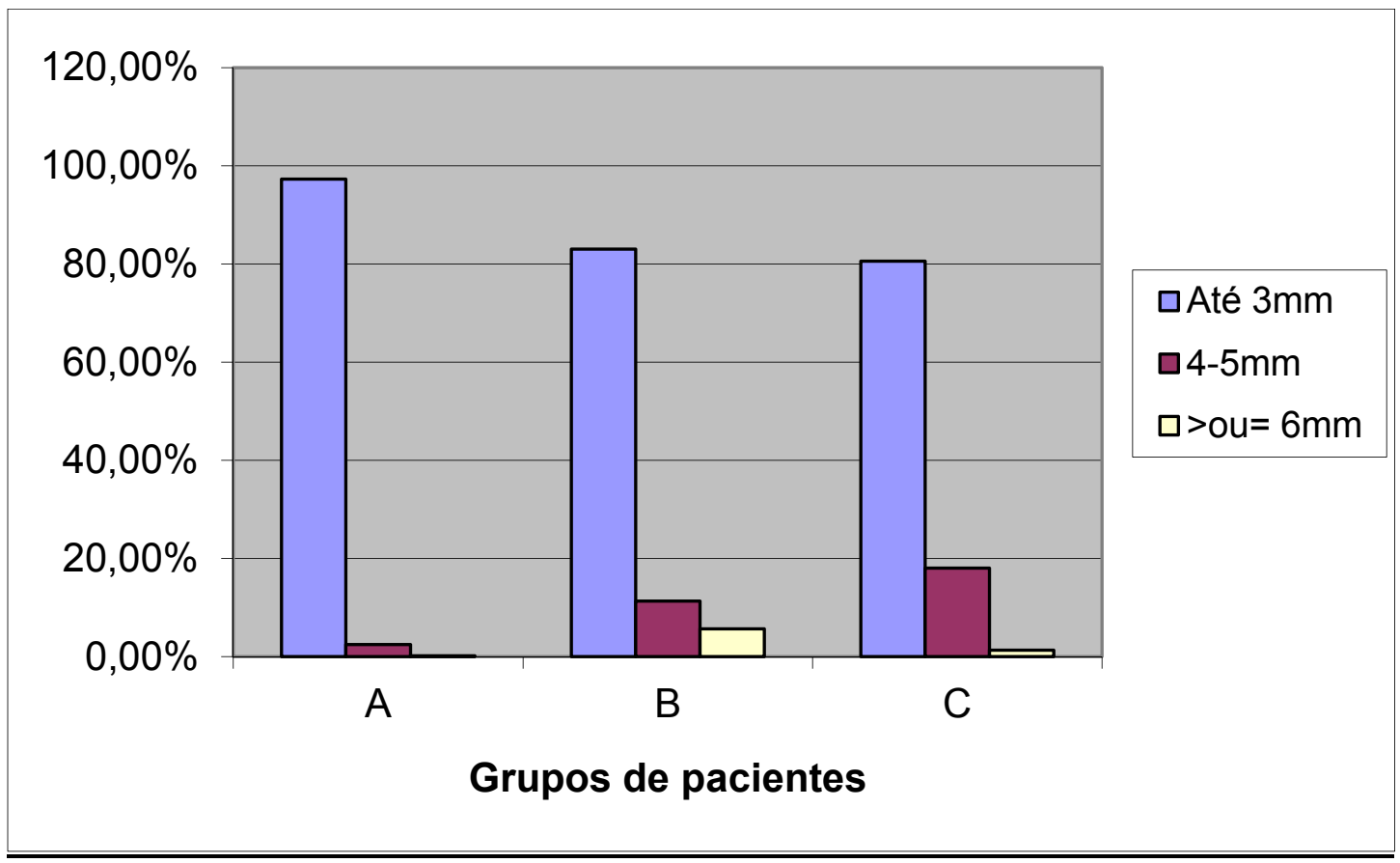

FIGURA 4 - Gráfico demonstrativo dos valores médios das profundidades de sondagem de até $3 \mathrm{~mm}$ entre 4 e $5 \mathrm{~mm}$ e igual ou superior a $6 \mathrm{~mm}$. 


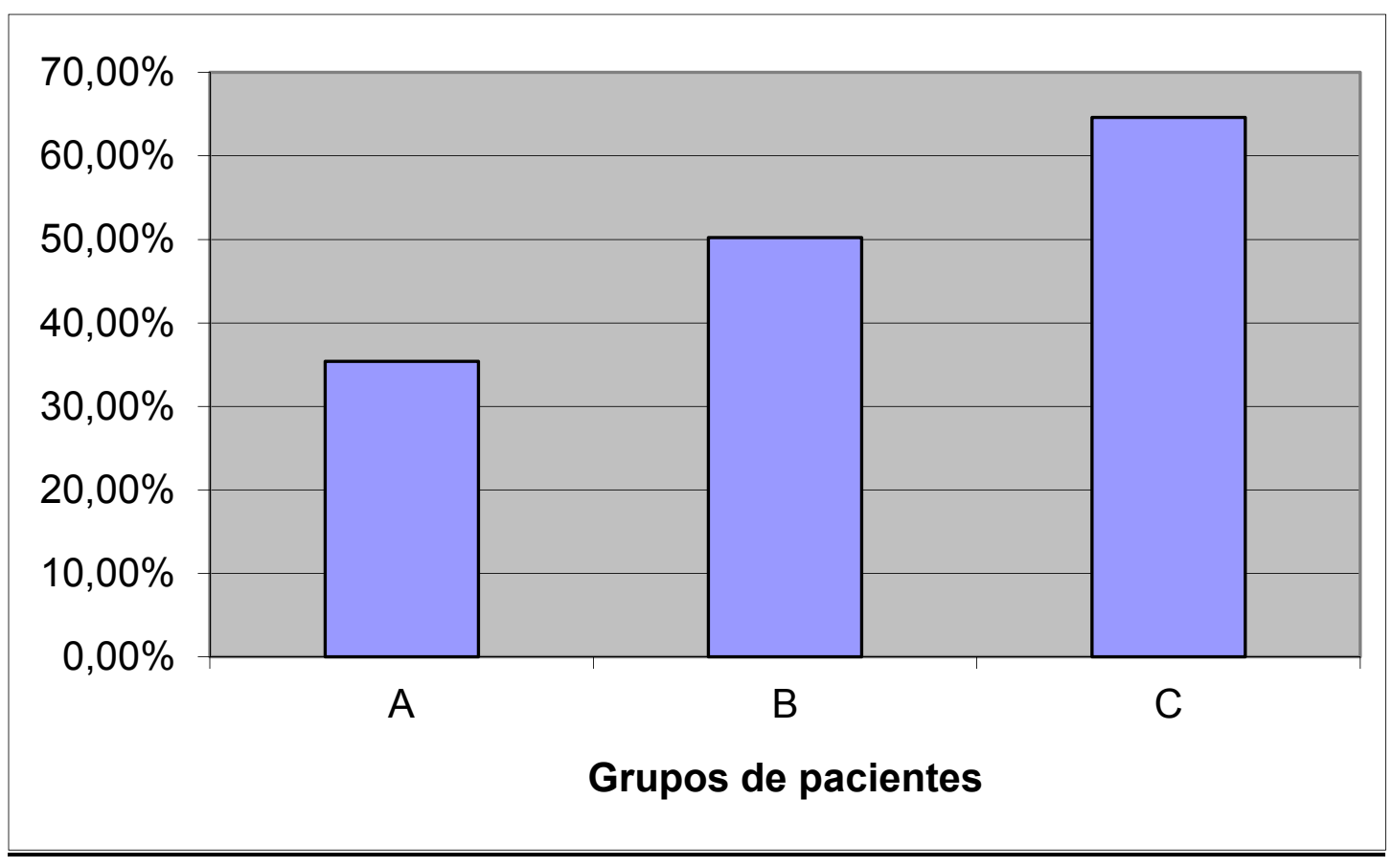

FIGURA 5 - Gráfico demonstrativo dos valores médios do índice de sangramento gengival nos grupos de paciente estudados.

Ao aplicar o teste não paramétrico de Kruskall Wallis by Ranks e tendo verificado significância estatística $(p \leq 0,05)$, aplicou-se o teste de Dunn para comparações individuais entre os grupos, observando-se C (TABELA 4). 
TABELA 4 - Comparações dos índices periodontais clínicos dos três grupos pelo teste de Dunn.

\begin{tabular}{lll}
\hline Grupos de pacientes & $\begin{array}{c}\text { Índices periodontais } \\
\text { clínicos }\end{array}$ \\
\hline A X C & IP & $\mathrm{p}=0,0171$ \\
& ISG & $\mathrm{p}=0,0389$ \\
& NIC & $\mathrm{p}=0,0084$ \\
& PS (4-5mm) & $\mathrm{p}=0,039$ \\
A X B & NIC & $\mathrm{p}=0,0084$ \\
C X B & PS (4-5mm) & $\mathrm{p}=0,039$
\end{tabular}

IP = Índice de Placa; ISG = Índice de Sangramento Gengival; IG = Índice Gengival;

NIC = Nível de Inserção Clínica; PS = Profundidade de Sondagem.

* estatisticamente significantes $(p \leq 0,005)$

Não sendo considerado o número de amostras em cada indivíduo, a TABELA 5 e a FIGURA 6 mostram a distribuição dos pacientes diabéticos tipo1 (grupos A e B) e controle (grupo C) positivos e negativos em relação à frequência de culturas para leveduras amostradas da cavidade bucal. Ao serem correlacionados os resultados positivos com os negativos, nenhuma significância estatística significante foi demonstrada pelo Teste do Qui-quadrado $\chi \cdot 2=1,5(p=0,472)$. 
TABELA 5 - Frequência dos pacientes diabéticos tipo1 (grupos A e B) e controles $(C)$ quanto aos resultados das culturas de leveduras das amostras da cavidade bucal.

\begin{tabular}{llcl}
\hline GRUPOS DE & \multicolumn{2}{c}{ RESULTADOS DAS CULTURAS } & TOTAL \\
PACIENTES & \multicolumn{2}{c}{ PARA LEVEDURAS } \\
\cline { 2 - 3 } & Positivos & Negativos \\
\hline A & $2(8,33 \%)$ & $6(25,00 \%)$ & $8(33,33 \%)$ \\
B & $4(16,66 \%)$ & $4(16,66 \%)$ & $8(33,33 \%)$ \\
C & $2(8,33 \%)$ & $6(25,00 \%)$ & $8(33,33 \%)$ \\
Total & $8(33,33 \%)$ & $16(66,66 \%)$ & $24(100 \%)$ \\
\hline
\end{tabular}

$\chi \cdot 2=0,133 ;$ ns $=$ não estatisticamente significante $(p=0,472)$

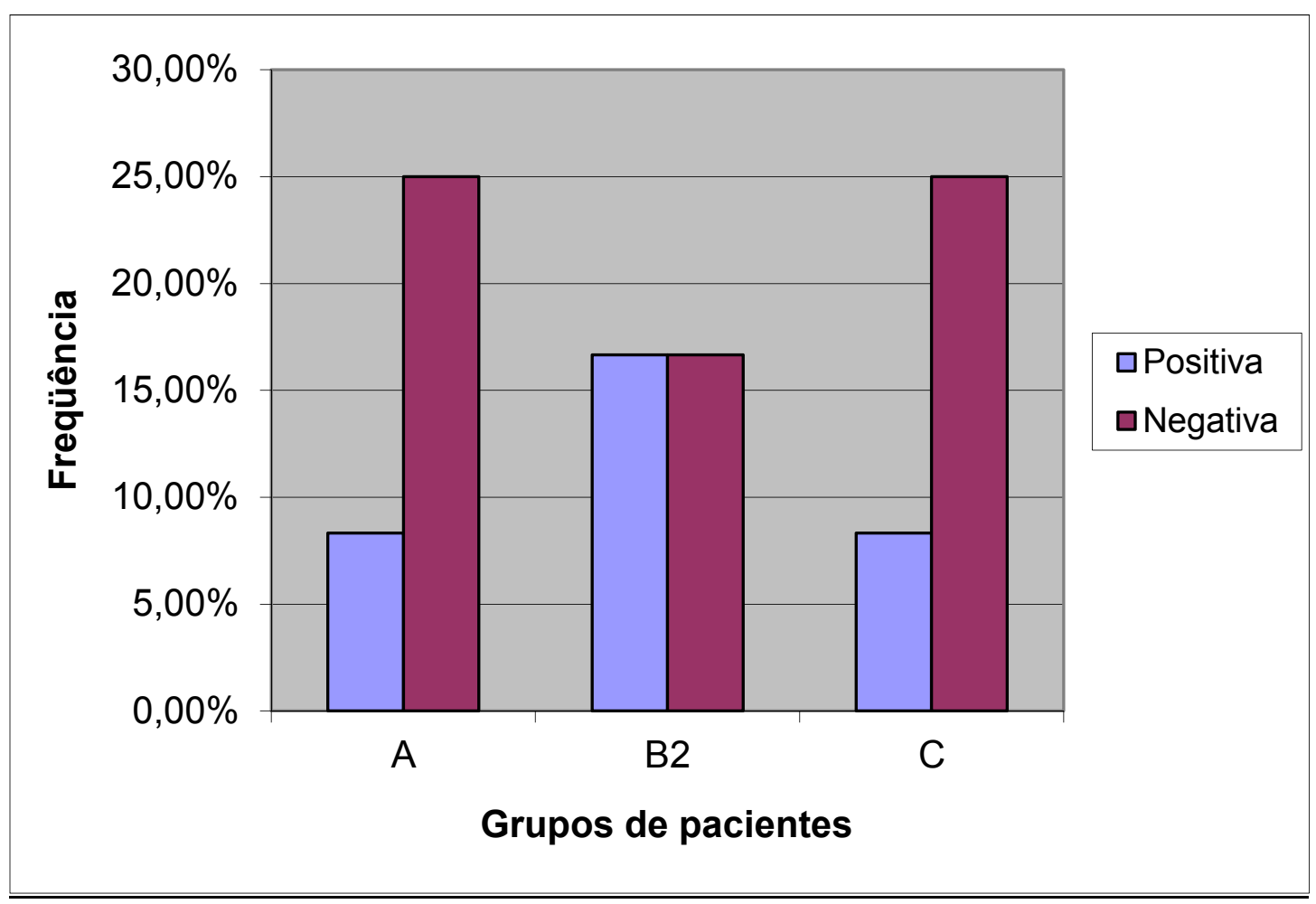

FIGURA 6 - Gráfico que ilustra a frequência de pacientes diabéticos tipo 1 (A e B) e dos pacientes controles quanto aos resultados das culturas de leveduras das amostras da cavidade bucal. 
Os índices periodontais clínicos de pacientes com culturas positivas ou negativas para leveduras são apresentados na TABELA 6 e nas FIGURAS 7, 8 e 9, onde não foram verificadas diferenças estatísticas significantes entre os índices periodontais clínicos dos grupos de pacientes positivos e negativos quanto aos resultados das culturas para leveduras amostradas da cavidade bucal.

TABELA 6 - Índices periodontais clínicos de pacientes com culturas positivas $(n=8)$ ou negativas $(n=6)$ para leveduras.

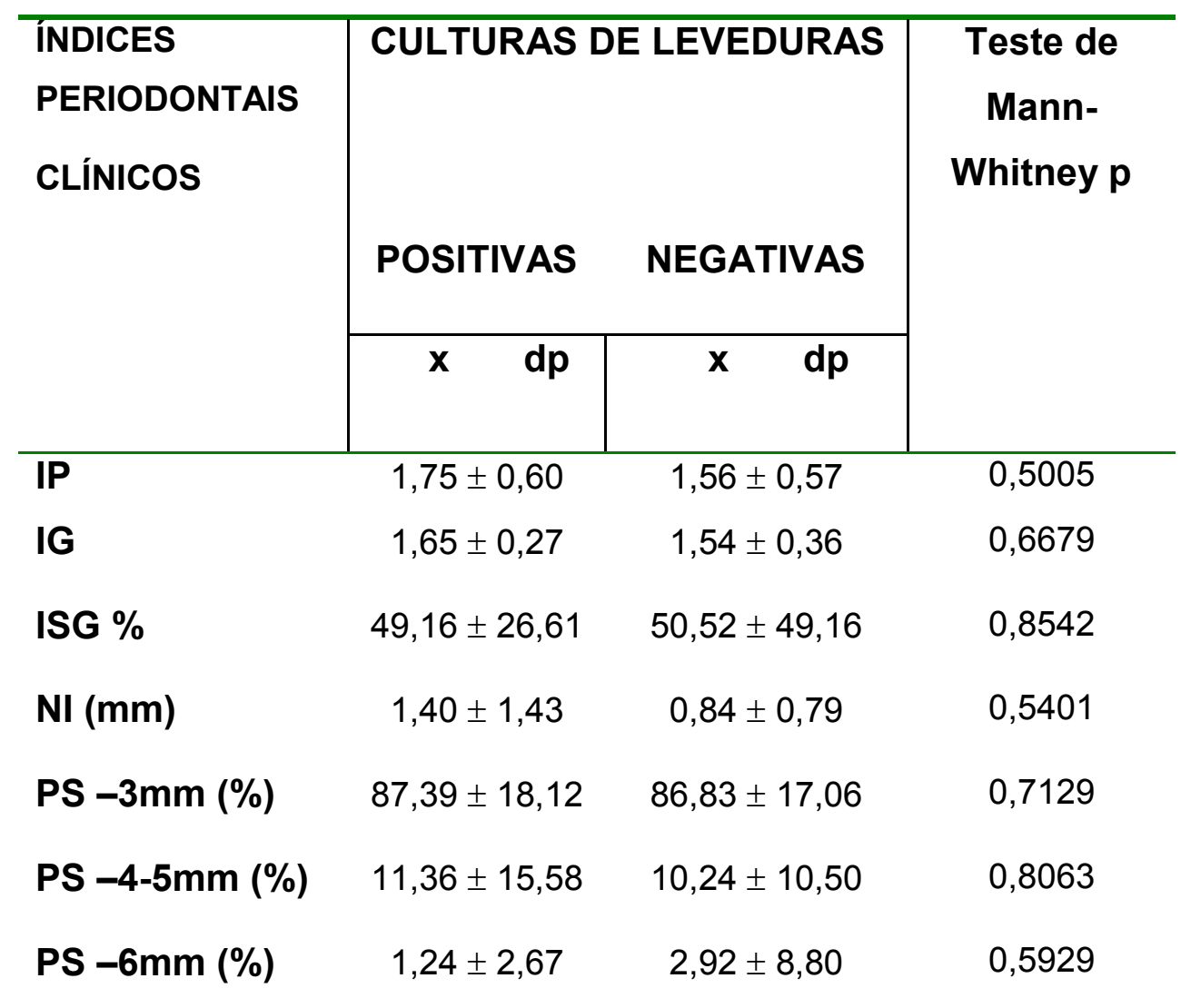

$\mathrm{IP}=$ Índice de placa; $\mathrm{IG}=$ Índice gengival; $\mathrm{ISG}=$ Índice de sangramento gengival; $\mathrm{N} I \mathrm{C}=$ nível de inserção clínica; PS= Profundidade de sondagem.

Ns. diferença estatística não significante $(p \geq 0,05)$ 


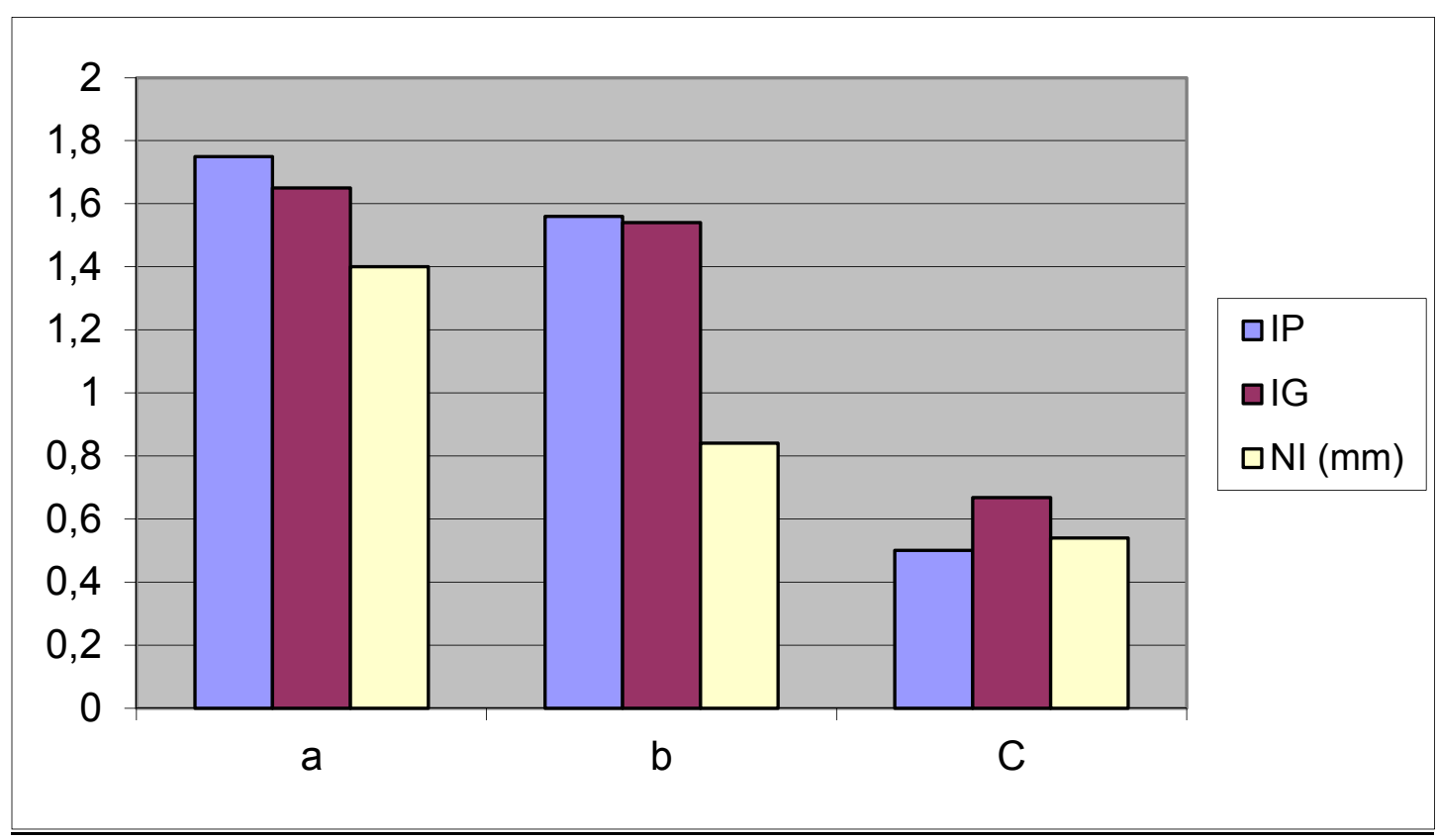

FIGURA 7 - Gráfico representativo dos valores médios do índice de placa, Índice gengival e nível de inserção clínica dos pacientes com culturas positivas e negativas para leveduras.

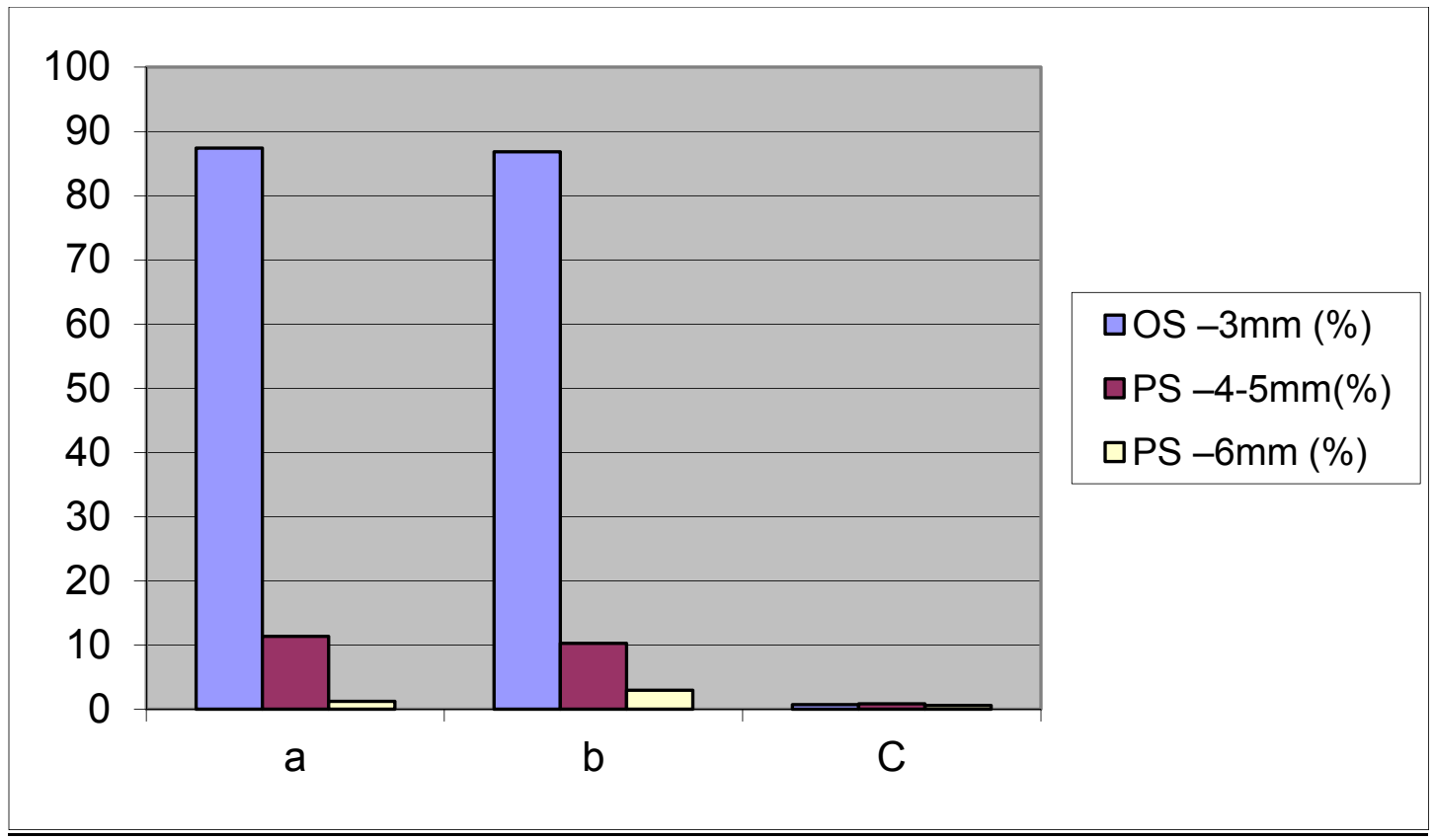

FIGURA 8 - Gráfico demonstrativo dos valores médios das profundidades de sondagem de até $3 \mathrm{~mm}$, entre 4 e $5 \mathrm{~mm}$ e igual ou superior a $6 \mathrm{~mm}$ dos pacientes com culturas positivas e negativas para leveduras. 


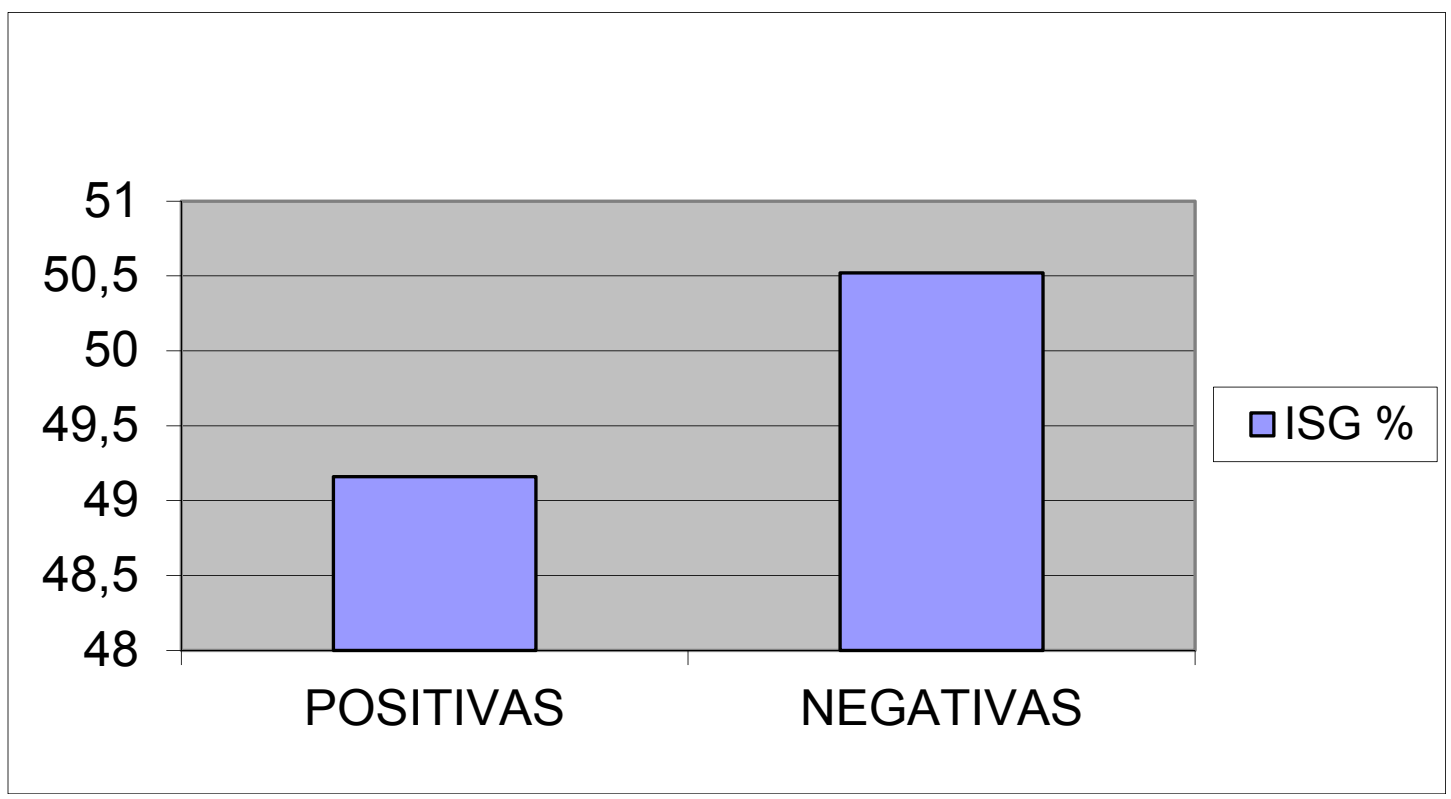

FIGURA 9 - Gráfico demonstrativo dos valores médios do índice de sangramento gengival nos grupos dos pacientes com culturas positivas e negativas para leveduras.

Pode-se constatar na TABELA 7 e na FIGURA 10, que dentre os 24 participantes desta pesquisa, oito se apresentaram colonizados por leveduras e, destes, 4 indivíduos apresentaram colonização em apenas 1 local amostrado, em 3 indivíduos em dois locais e em um 1 indivíduo foram isoladas leveduras dos três locais amostrados, perfazendo um total de 13 locais colonizados.

Entre os pacientes com culturas positivas para leveduras, 1 apresentou levedura somente no sulco saudável, 2 apenas no sulco comprometido, 1 apenas na saliva, 2 no sulco saudável e na saliva, 1 no sulco comprometido e na saliva, e por fim, 1 apresentou em 2 sítios e na saliva. Observou-se que houve um maior número de colônias nas coletas obtidas da saliva dos pacientes diabéticos mais velhos $(57,14 \%)$. TABELA 7 e FIGURA 10. 
TABELA 7 - Distribuição Bruta das culturas positivas das amostras isoladas da cavidade bucal e os respectivos números de colônias de leveduras, por pacientes.

\section{Grupo de}

Pacientes

\section{SULCO}

\section{Saliva}

\section{Saudável Comprometido}

\begin{tabular}{llll}
\hline A.5 & 0 & 4 & 3 \\
A.8 & 0 & 0 & 1 \\
B.2 & 4 & 0 & 26 \\
B.3 & 2 & 1 & 10 \\
B.7 & 0 & 3 & 0 \\
B.8 & 1 & 0 & 0 \\
C.1 & 0 & 5 & 0 \\
C.2 & 2 & 0 & 1 \\
Total de pacientes & 4 & 4 & 5 \\
Número/colônias & 9 & 13 & 41 \\
\hline
\end{tabular}

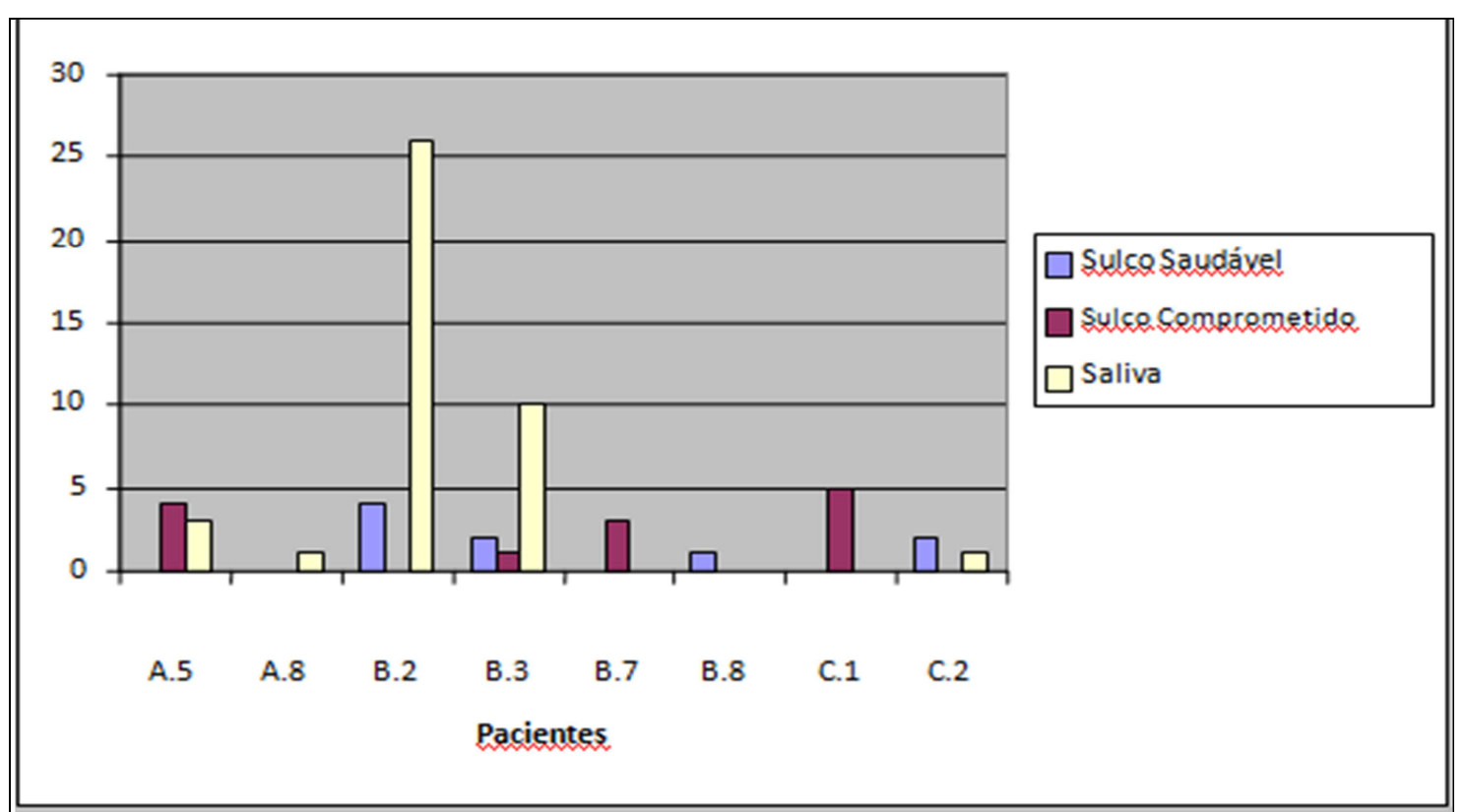

FIGURA 10 - Distribuição Bruta das culturas positivas das amostras isoladas da cavidade bucal e os respectivos números de colônias de leveduras, por paciente. 
Na TABELA 8 e na FIGURA 11, visualiza-se a distribuição dos treze locais (18\%) que tiveram a cultura positiva para leveduras, do total de 72 locais amostrados, onde 4 foram do sulco saudável, 4 do sulco comprometido (bolsa) e 5 da saliva. Entre os pacientes diabéticos do grupo A foram encontradas 1 cultura positiva para levedura no sulco comprometido e 2 na saliva. Já no grupo B ocorreram 3 culturas positivas do sulco saudável, 2 do sulco comprometido e 2 na saliva enquanto nos pacientes controle houve positividade em apenas 1 cultura de cada sulco gengival amostrado. Aplicando-se o Teste do Qui-quadrado verificou-se que não houve diferenças significativas $(\chi .2=2,105)(p=0,717)$ entre os locais amostrados e os grupos estudados.

TABELA 8 - Distribuição das treze amostras da cavidade bucal que apresentaram culturas positivas de leveduras.

\begin{tabular}{|c|c|c|c|c|}
\hline Grupo & $\begin{array}{c}\text { Sulco } \\
\text { Saudável }\end{array}$ & $\begin{array}{c}\text { Sulco } \\
\text { Comprometido }\end{array}$ & Saliva & Total \\
\hline A & $0(0,00 \%)$ & $1(7,69 \%)$ & $2(15,38 \%)$ & $3(23,08 \%)$ \\
\hline B & $3(23,08 \%)$ & $2(15,38 \%)$ & $2(15,38 \%)$ & $7(53,85 \%)$ \\
\hline C & $1(07,69 \%)$ & $1(7,69 \%)$ & $1(7,69 \%)$ & $3(23,08 \%)$ \\
\hline Total & $4(30,77 \%)$ & $4(30,77 \%)$ & $5(38,46 \%)$ & $13(100 \%)$ \\
\hline
\end{tabular}




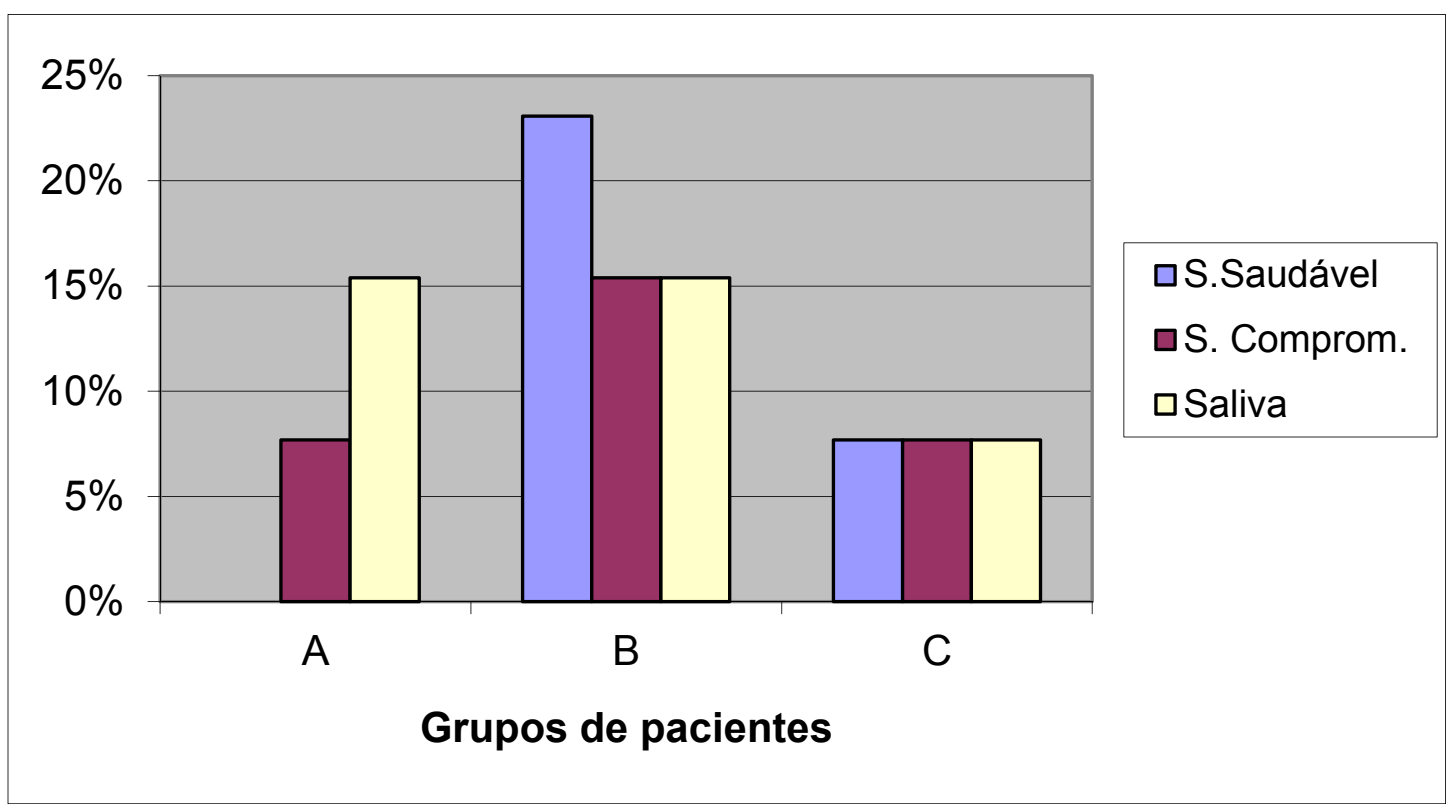

FIGURA 11 - Gráfico ilustrativo da distribuição das treze amostras da cavidade bucal com culturas positivas para leveduras.

Entre os pacientes diabéticos tipo1, tanto o grupo A como o grupo B, apresentava 3 indivíduos positivos para leveduras no sulco comprometido e 3 indivíduos positivos no sulco saudável. O grupo A tinha apenas 1 sulco comprometido com leveduras, enquanto que, no grupo B havia 2 sulcos comprometidos e 3 sulcos saudáveis positivos. Ao serem avaliados os sulcos gengivais comprometidos e saudáveis estabeleceu-se uma comparação entre os diabéticos tipo 1 (grupos $A+B$ ) e os pacientes controles, visualizados na TABELA 9 e na FIGURA 12, não foram verificadas diferenças estatisticamente significantes entre a presença de levedura nos sulcos gengivais e os grupos de pacientes pesquisados, pelo Teste de Fisher $(p=1,000)$. 
TABELA 9 - Comparação entre presença de leveduras nos sulcos comprometidos e saudáveis, dos diabéticos (grupos $A+B$ ) e controles $(C)$

\begin{tabular}{lccc}
\hline \multirow{2}{*}{ GRUPO } & \multicolumn{2}{c}{ SULCO } & Total \\
\cline { 2 - 4 } & Comprometido & Saudável & \\
\hline Diabéticos $(\mathbf{A}+\mathrm{B})$ & $3(1+2)$ & $3(0+3)$ & 6 \\
\hline Controles & 1 & 1 & 2 \\
\hline Total & 4 & 4 & 8 \\
\hline
\end{tabular}

ns= estatísticas não significantes; - Teste de Fisher $(p=1,000)$

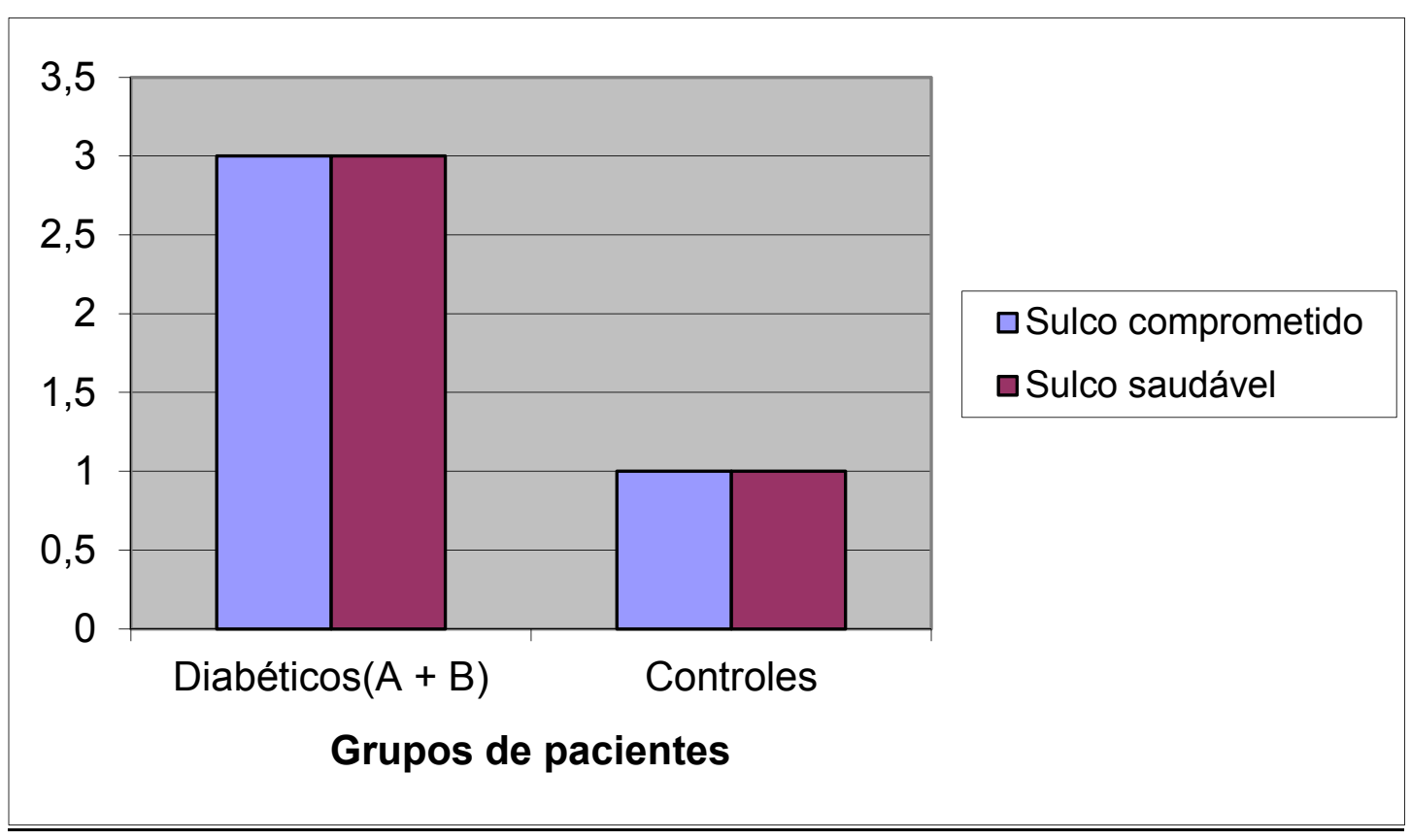

FIGURA 12 - Comparação entre pacientes diabéticos (grupos A + B) e controles (grupo $\mathrm{C}$ ) quanto à presença de leveduras no sulco gengival.

Entre as leveduras isoladas foram identificadas quatro espécies diferentes, sendo a Candida albicans a mais frequente. A TABELA 10 e na FIGURA 13 mostram a frequência das espécies de leveduras que foram isoladas, do total de treze locais: 8 amostras $(61,53 \%)$ 
de Candida albicans, 2 amostras (15,38\%) de Candida glabrata, 2 amostras (15,38\%) de Candida parapsilosis, 1 amostra (7,69\%) de Trischoporon ovoides. Empregando-se o Teste Qui-quadrado averiguamos que não houve associação entre os locais e as espécies isoladas $(\chi \cdot 2=$ $7,23)(p=0,3)$.

TABELA 10- Leveduras isoladas conforme a espécie por local amostrado.

\begin{tabular}{|c|c|c|c|}
\hline \multirow[t]{3}{*}{ Espécies isoladas } & \multicolumn{3}{|c|}{ LOCAL AMOSTRADO } \\
\hline & \multirow{2}{*}{ Saliva } & \multicolumn{2}{|c|}{ SULCO } \\
\hline & & Saudável & Comprometido \\
\hline Candida albicans & $3(23,08 \%)$ & $2(15,38 \%)$ & $3(23,08 \%)$ \\
\hline Candida glabrata & $0(00,00 \%)$ & $2(15,38 \%)$ & $0(00,00 \%)$ \\
\hline Candida parapsilosis & $1(7,69 \%)$ & $0(00,00 \%)$ & $1(7,69 \%)$ \\
\hline Trichosporon ovoides & $1(7,69 \%)$ & $0(00,00 \%)$ & $0(00,00 \%)$ \\
\hline Total & 5 & 4 & 4 \\
\hline
\end{tabular}

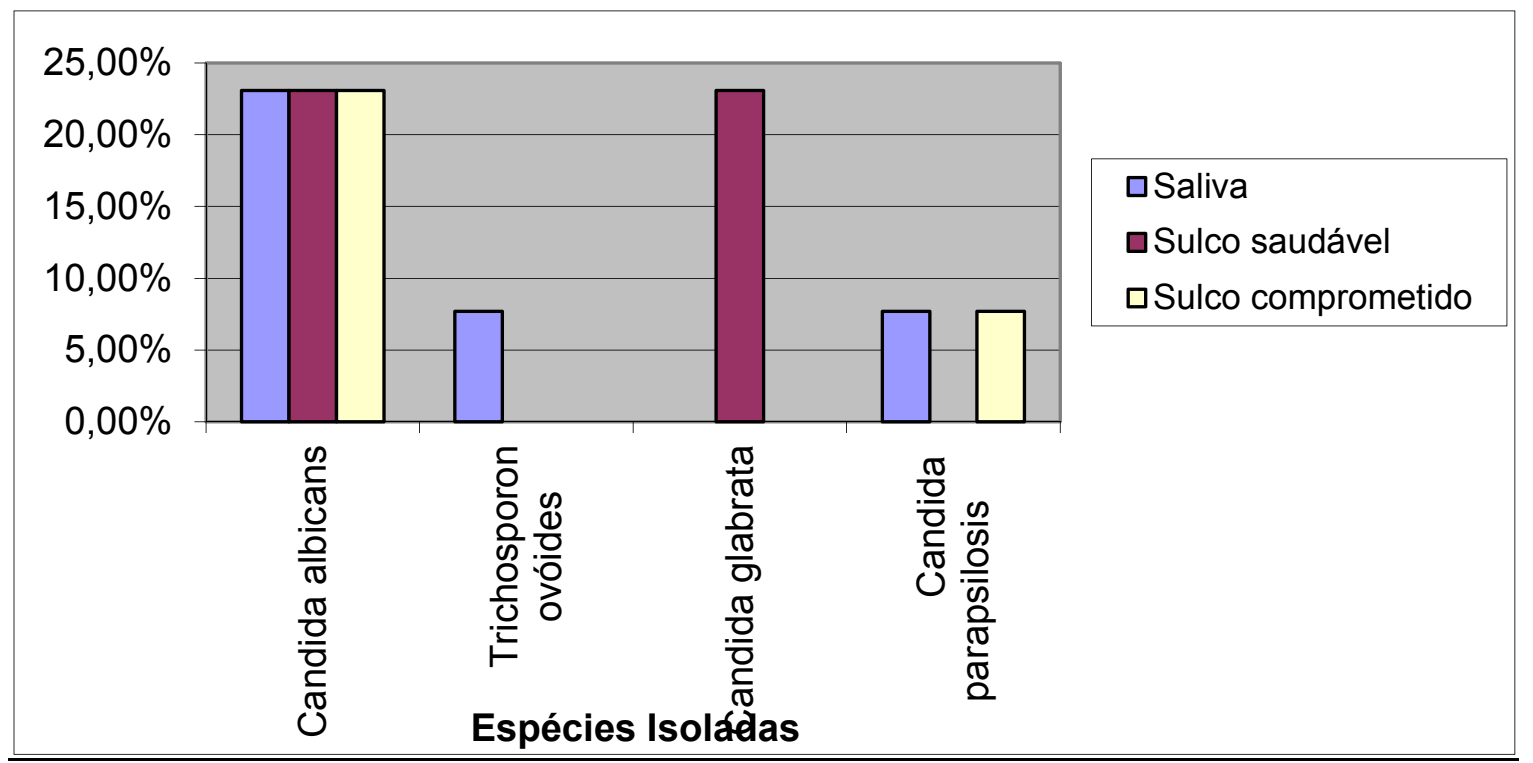

FIGURA 13 - Ilustra a frequência de leveduras isoladas conforme a espécie por local amostrado. 
Em relação ao controle glicêmico dos 16 pacientes diabéticos selecionados, simples e aleatoriamente, apenas 1 paciente foi considerado como bem controlado (DBC) (HbA1c entre 5 e 7,5\%), portanto, entre os demais 15 pacientes 7 deles eram diabéticos moderadamente controlados (DMC), com níveis de hemoglobina glicosilada médios de $9,25 \%$ e 8 pacientes eram diabéticos pobremente controlados (DPC), com taxa média de hemoglobina glicosilada de $12,82 \%$.

A distribuição dos pacientes diabéticos tipo1, dos grupos A e $B$, de acordo com seu controle glicêmico, é mostrada na TABELA 11 e na FIGURA 14, com o grupo A apresentando 2 pacientes moderadamente controlados (DMC) e 6 pacientes pobremente controlados (DPC) e o grupo $B$ contendo 1 paciente bem controlado (DBC), 5 pacientes moderadamente controlados (DMC) e 1 paciente pobremente controlado (DPC). O Teste do Qui-Quadrado não demonstrou diferenças estatísticas significantes na distribuição de paciente segundo seu controle glicêmico em cada grupo de pacientes diabéticos, $\chi \cdot 2=4,28(p=0,1173)$.

TABELA 11 - Distribuição dos pacientes diabéticos tipo1 conforme seu controle glicêmico (hemoglobina glicosilada).

\begin{tabular}{lllll}
\hline DIABÉTICOS & DBC & DMC & DPC & Total
\end{tabular}

\begin{tabular}{lllll}
\hline GRUPO A & 0 & 2 & 6 & 8 \\
GRUPO B & 1 & 5 & 2 & 8 \\
TOTAL & 1 & 7 & 8 & 16
\end{tabular}

DBC = diabetes bem controlada; DMC $=$ diabetes moderadamente controlada; DPC = diabetes pobremente controlada.

$-\chi .2=4,28$; ns= estatísticas não significantes $(p=0,1173)$ 


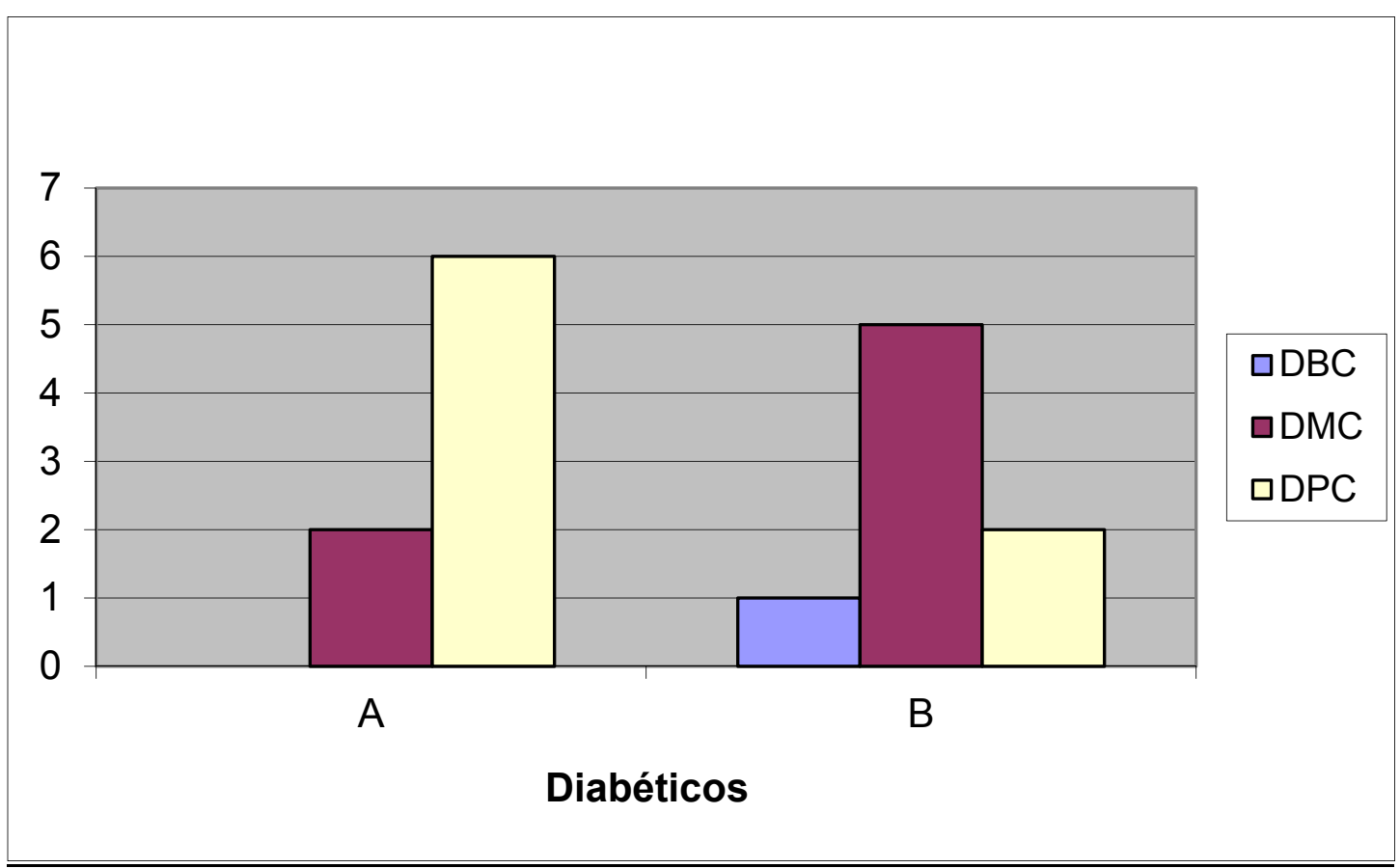

FIGURA 14 - Gráfico ilustrativo sobre a distribuição dos pacientes diabéticos tipo 1 conforme seu controle glicêmico (hemoglobina glicosilada).

Ao checarmos os dois grupos glicêmicos (DMC e DPC) em relação aos índices periodontais clínicos observou-se que houve diferenças intergrupos estatisticamente significantes entre os grupos do índice de placa ( $p=0,0206$ ) segundo o Teste de Mann-Whitney, onde os pacientes DMC apresentavam os maiores valores, como apresentado na TABELA 12 e nas FIGURAS 15, 16 e 17. 
TABELA 12 - Valores médios e desvios padrões dos índices periodontais clínicos dos pacientes diabéticos tipo1 moderadamente controlados (DMC) e pobremente controlados (DPC).

\begin{tabular}{|c|c|c|c|}
\hline \multirow{4}{*}{$\begin{array}{c}\text { ÍNDICES } \\
\text { PERIODONTAIS } \\
\text { CLÍNICOS }\end{array}$} & \multicolumn{2}{|c|}{ CONTROLE GLICÊMICO } & Teste de Mann- \\
\hline & \multirow[b]{2}{*}{ DMC } & \multirow[b]{2}{*}{ PMC } & $P$ \\
\hline & & & \\
\hline & $x \quad d p$ & $x \quad d p$ & \\
\hline IP & $1,77 \pm 1,177$ & $1,12 \pm 1,12$ & $0,0206^{*}$ \\
\hline IG & $1,56 \pm 0,25$ & $1,39 \pm 0,32$ & 0,3545 \\
\hline ISG \% & $52,02 \pm 31,73$ & $33,91 \pm 16,63$ & 0,3545 \\
\hline $\mathrm{NI}(\mathrm{mm})$ & $1,60 \pm 1,55$ & $0,48 \pm 0,35$ & 0,1324 \\
\hline PS -3mm (\%) & $81,22 \pm 27,97$ & $97,59 \pm 2,16$ & 0,2715 \\
\hline PS -4-5mm (\%) & $12,48 \pm 17,73$ & $2,19 \pm 2,05$ & 0,2471 \\
\hline PS -6mm (\%) & $6,28 \pm 13,28$ & $0,20 \pm 0,40$ & 0,4519 \\
\hline
\end{tabular}

$\mathrm{IP}=$ Índice de placa; $\mathrm{IG}=$ Índice gengival; $I S G=$ Índice de sangramento gengival; $\mathrm{NIC}=$ nível de inserção clínica; PS= Profundidade de sondagem.

* Estatística significante; Teste de Mann-Whitney

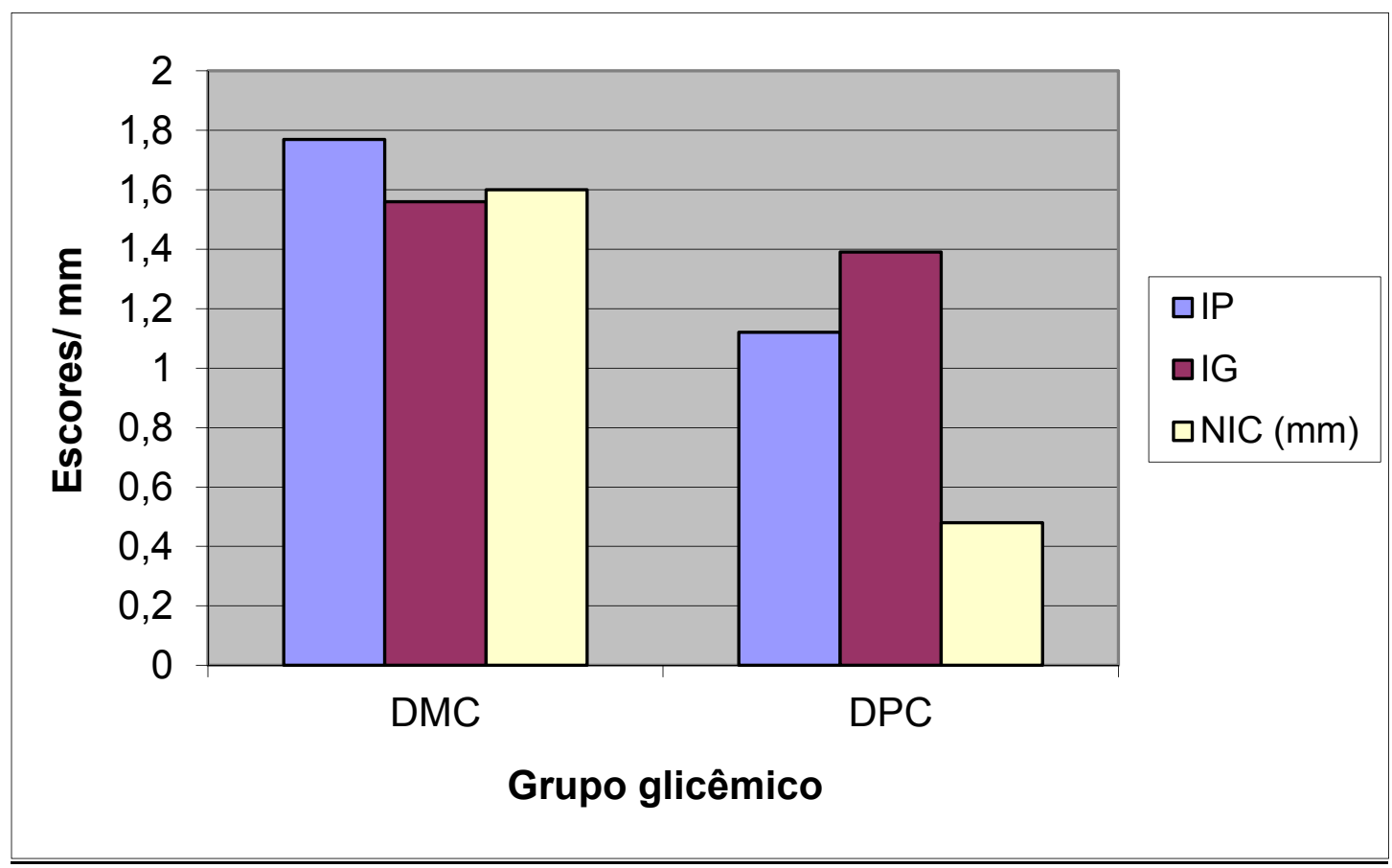

FIGURA 15 - Valores médios do índice de placa índice gengival e nível de inserção pacientes diabéticos tipo 1 moderadamente controlados (DMC) e pobremente controlados (DPC). 


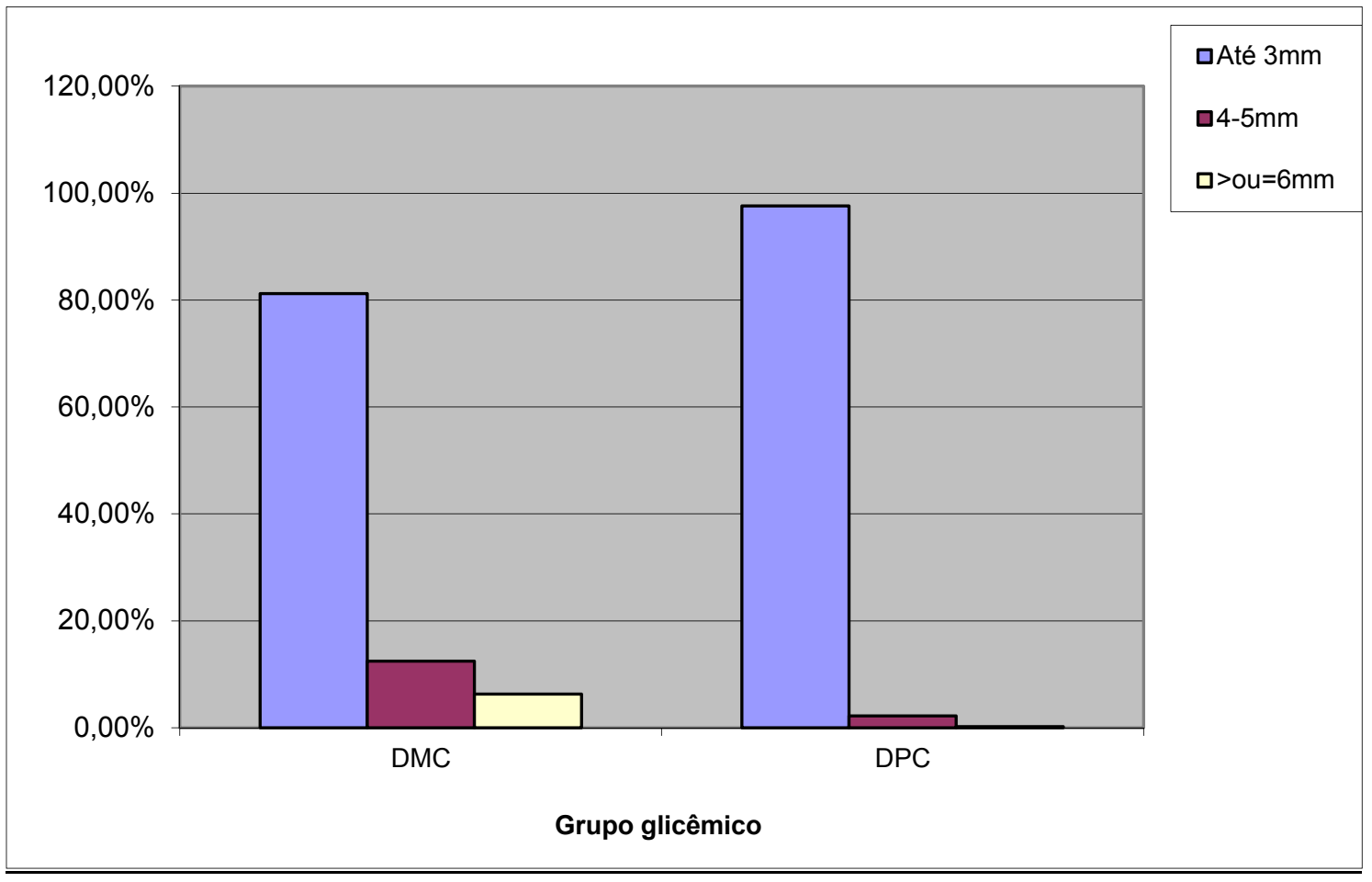

FIGURA 16 - Valores médios das profundidades de sondagem em paciente diabéticos tipo 1 moderadamente controlados (DMC) e pobremente controlados (DPC).

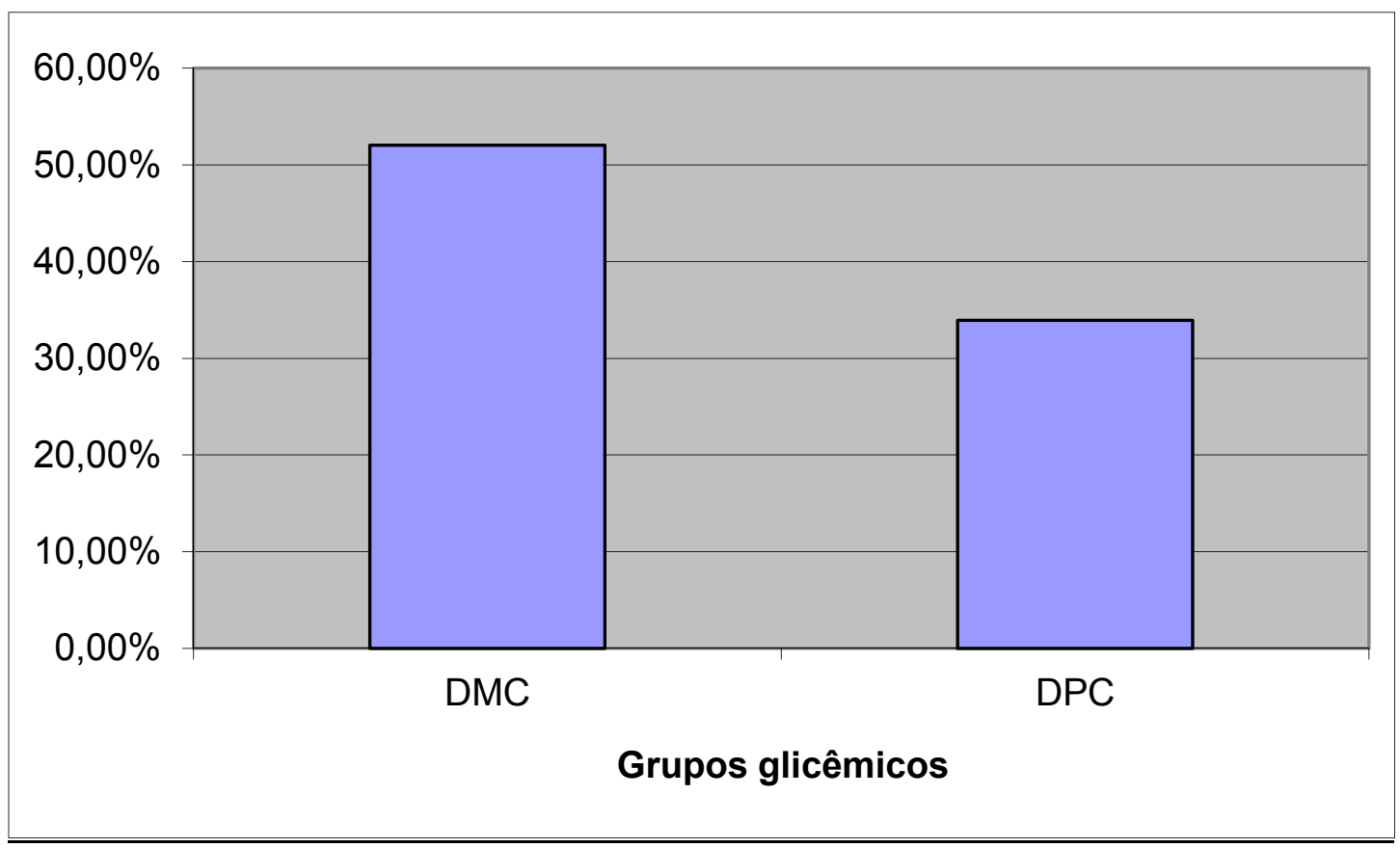

FIGURA 17 - llustra os valores médios do índice de sangramento gengival (ISG) dos pacientes diabéticos tipo 1, moderadamente controlados (DMC) e pobremente controlados (DPC). 
Ao compararmos dentro dos dois grupos diabéticos os pacientes moderadamente controlados com os pobremente controlados em relação à presença de lesões bucais não fúngicas, não foi demonstrada nenhuma diferença significante, utilizando-se o Teste do Qui-quadrado ( $\chi .2=$ $0,714)(p=0,398)$, conforme mostra a TABELA 13 e FIGURA 18.

TABELA 13 - Frequência observada das lesões de mucosa bucal conforme o comportamento glicêmico do paciente moderadamente e pobremente controlado.

\begin{tabular}{|c|c|c|c|}
\hline \multirow[t]{2}{*}{$\begin{array}{l}\text { PACIENTES } \\
\text { DIABÉTICOS }\end{array}$} & \multicolumn{2}{|c|}{ LESÃO DE MUCOSA } & \multirow[t]{2}{*}{ TOTAL } \\
\hline & PRESENTE & AUSENTE & \\
\hline DPC & $4(50,00 \%)$ & $4(50,00 \%)$ & 8 \\
\hline $\begin{array}{l}\text { DMC } \\
\text { TOTAL }\end{array}$ & $\begin{array}{c}2(28,57 \%) \\
6\end{array}$ & $\begin{array}{c}5(71,43 \%) \\
9\end{array}$ & $\begin{array}{c}7 \\
15\end{array}$ \\
\hline
\end{tabular}

DMC= diabetes moderadamente controlada; $\mathrm{DPC}=$ diabetes pobremente controlada.

- Ns= estatísticas não significantes Teste Exato de Fisher $(p=0,608)$

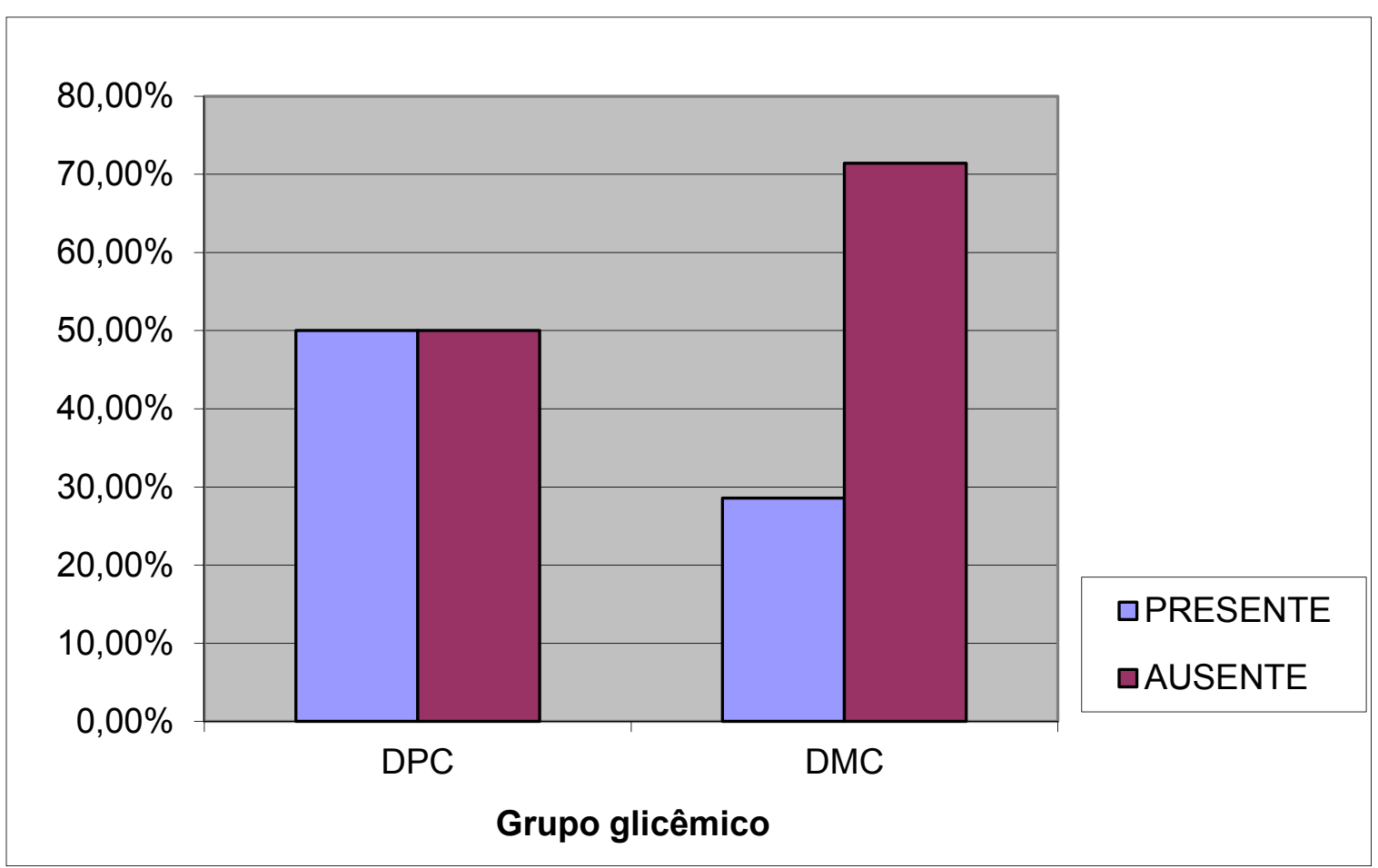

FIGURA 18 - Ilustra a frequência observada das lesões de mucosa bucal conforme o comportamento glicêmico do paciente (moderadamente e pobremente controlado). 
Entre os indivíduos acometidos pelo diabetes mellitus ( $\mathrm{A}$ e B) 1 paciente se apresentava bem controlado e sem leveduras (DBC), 4 amostras $(57,14 \%)$ foram encontradas entre os pacientes moderadamente controlados e 2 amostras (25,00\%) foram detectadas entre os pobremente controlados. Usando-se o Teste do Qui-quadrado $(\chi .2=1,607)$, não foi verificada associação entre o controle glicêmico e a presença de levedura $(p=0,204)$. Dentre as culturas positivas $(40 \%)$ em cavidade bucal de pacientes portadores de DM, 4 (66,66\%) eram diabéticos moderadamente controlados (DMC) e $2(33,33 \%)$ eram diabéticos pobremente controlados (DPC). A TABELA 14 mostra a distribuição das culturas positivas para leveduras amostradas da cavidade bucal, de acordo com o comportamento glicêmico dos diabéticos.

TABELA 14 - Frequência de culturas positivas para leveduras das amostras isoladas da cavidade bucal de diabéticos tipo 1 , em relação ao seu comportamento glicêmico.

\begin{tabular}{cccc}
\hline Diabéticos & \multicolumn{2}{c}{ CULTURAS para LEVEDURAS } & \multirow{2}{*}{ Total } \\
\cline { 2 - 3 } & negativas & positivas & \\
\hline DMC & 3 & 4 & $7(100 \%)$ \\
DPC & $(42,86 \%)$ & $(57,14 \%)$ & $8(100 \%)$ \\
TOTAL & 6 & 2 & 15 \\
& $(75,00 \%)$ & $(25,00 \%)$ & $(100 \%)$ \\
& 9 & 6 & $(40 \%)$ \\
\end{tabular}

DMC = diabéticos moderadamente controlados; DPC = diabéticos pobremente controlados.

$\chi \cdot 2=1,607 ;$ ns. estatística não significante $(p=0,204)$. 


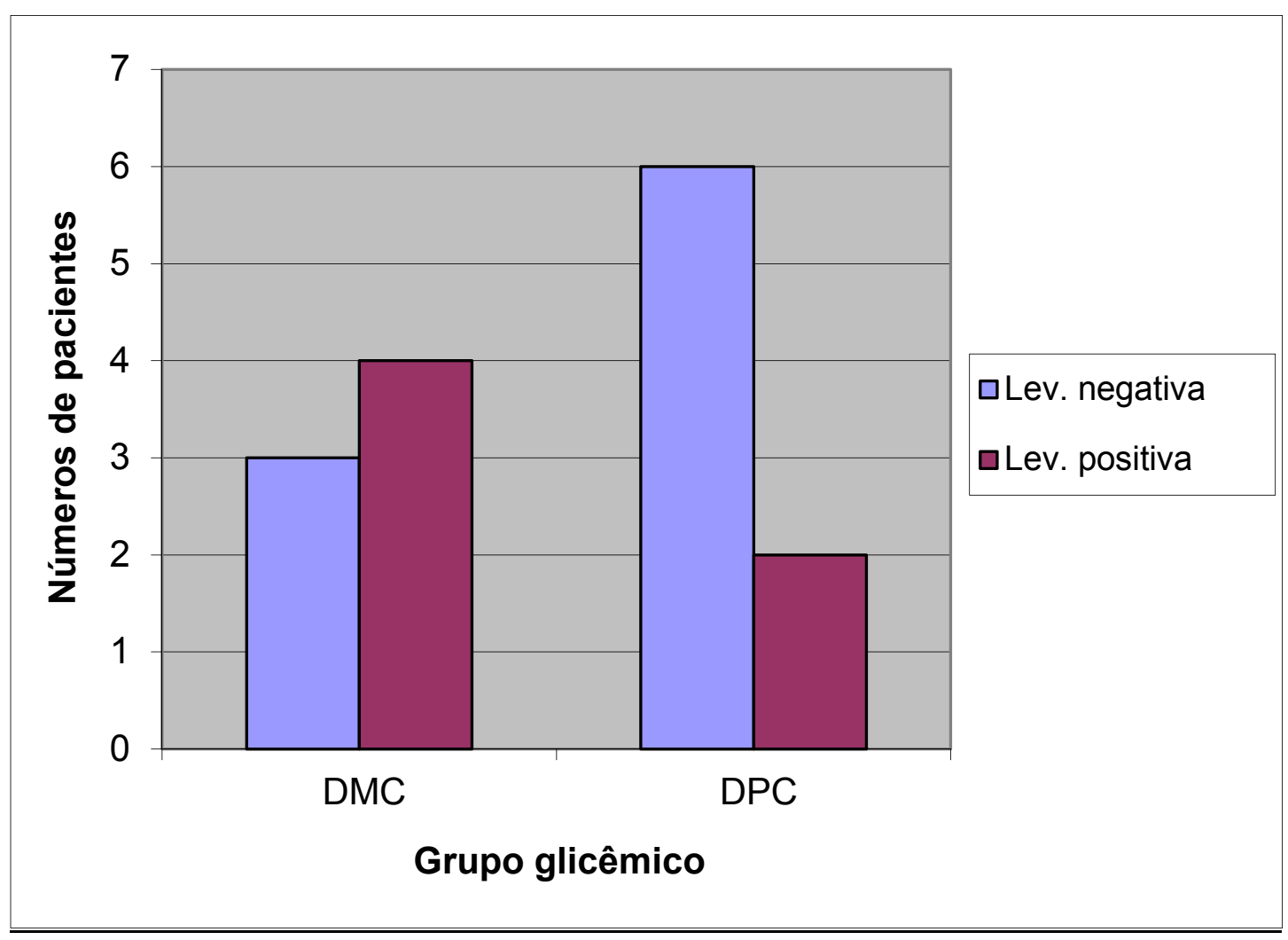

FIGURA 19 - Ilustra a frequência de culturas positivas para leveduras das amostras isoladas da cavidade bucal de diabéticos tipo 1 , em relação ao seu comportamento glicêmico.

A TABELA 15 mostra somente a distribuição de resultados positivos (40\%) das culturas para leveduras amostradas da cavidade bucal de pacientes diabéticos, segundo seu comportamento glicêmico em moderadamente e pobremente controlados. Evidenciou-se que no grupo $A$ havia 1 paciente MC $(16,67 \%)$ e outro PC $(16,67 \%)$ portadores de leveduras, enquanto no grupo B foram encontrados 3 pacientes DMC (50\%) e 1 paciente DPC $(16,67 \%)$, também positivos para leveduras nas amostras da cavidade bucal. 
TABELA 15 - Frequência de leveduras por grupo diabético (A e $B$ ), de acordo com o comportamento glicêmico do paciente (DMC moderadamente controlado e DPC - pobremente controlado).

\begin{tabular}{lcc}
\hline GRUPOS & DMC & DPC \\
\hline A & $1(16,67 \%)$ & $1(16,67 \%)$ \\
B & $3(50,00 \%)$ & $1(16,67 \%)$ \\
\hline
\end{tabular}

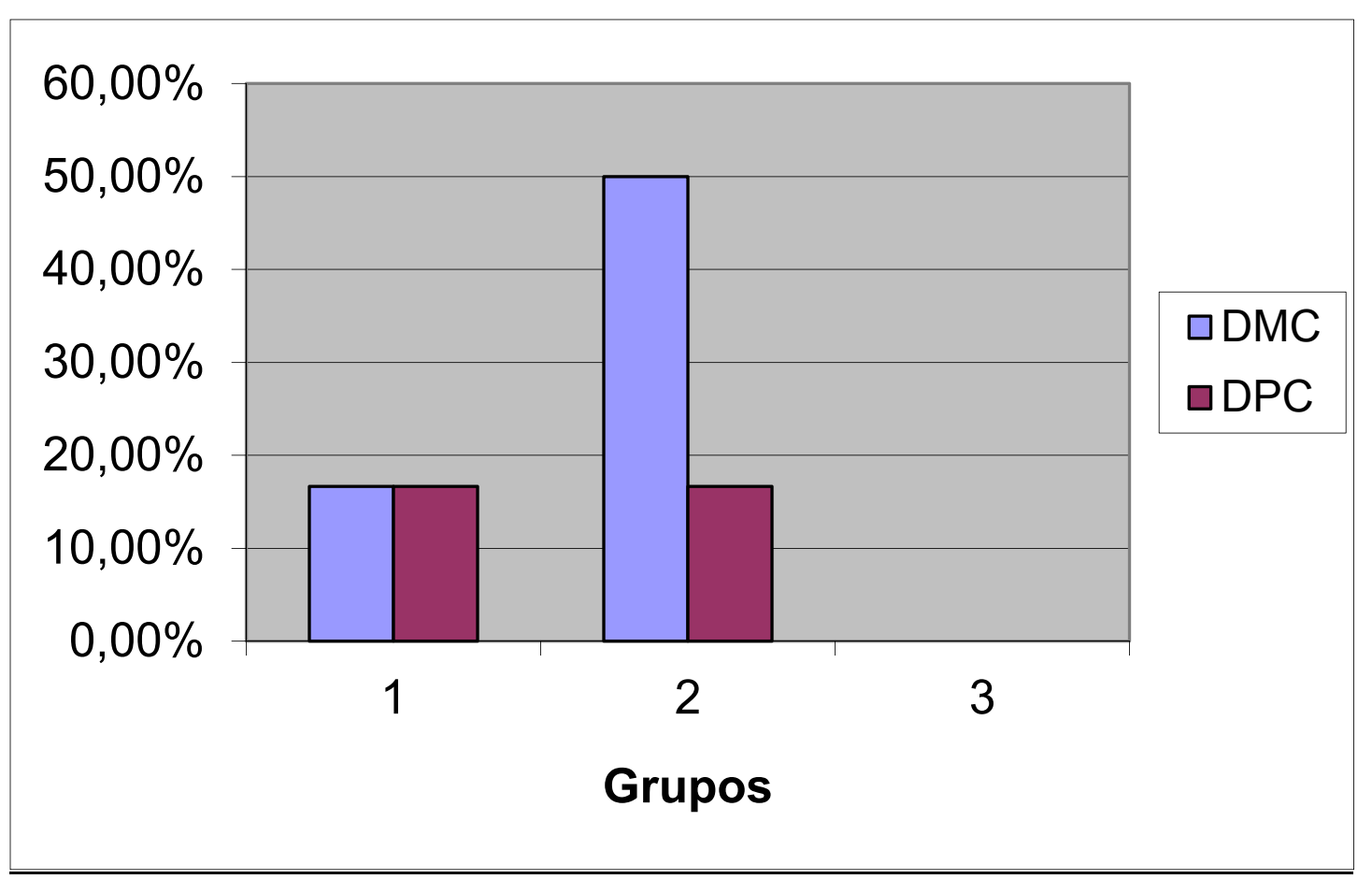

FIGURA 20 - Gráfico ilustrativo da frequência de leveduras por grupo diabético ( $\mathrm{A}$ e $\mathrm{B}$ ), de acordo com o comportamento glicêmico do paciente (DMC- moderadamente controlado e DPC- pobremente controlado).

Os pacientes foram classificados de acordo com seu fluxo. Ainda que nenhuma diferença estatística significante tenha sido demonstrada pelo Teste do Qui-quadrado $\chi \cdot 2=8,65(p=0,0704)$ a TABELA 16 e na FIGURA 21, mostra que os três grupos estudados $A, B$ e $C$. apresentaram predomínio, consecutivamente, de hipossalivação (62,5\%), da salivação normal $(62,5 \%)$ e de baixa salivação $(50 \%)$. 
TABELA 16 - Classificação dos pacientes pesquisados de acordo com o fluxo salivar e distribuídos em cada grupo pesquisado.

\section{FLUXO SALIVAR}

\section{GRUPOS DE}

TOTAL

\section{PACIENTES}

\begin{tabular}{lllll} 
& HIPOSSALIVAÇÃO & NORMAL & \multicolumn{1}{l}{ BAIXA } & \\
\hline A & $5(62,50 \%)$ & $1(12,50 \%)$ & $2(25,00 \%)$ & 8 \\
B & $3(37,50 \%)$ & $5(62,50 \%)$ & $0(0,00 \%)$ & 8 \\
C & $2(25,00 \%)$ & $2(25,00 \%)$ & $4(50,00 \%)$ & 8 \\
TOTAL & 10 & 8 & 6 & 24 \\
\hline
\end{tabular}

$\chi \cdot 2=8,65 ; \mathrm{ns}=$ estatística não significante $(p=0,0704)$.

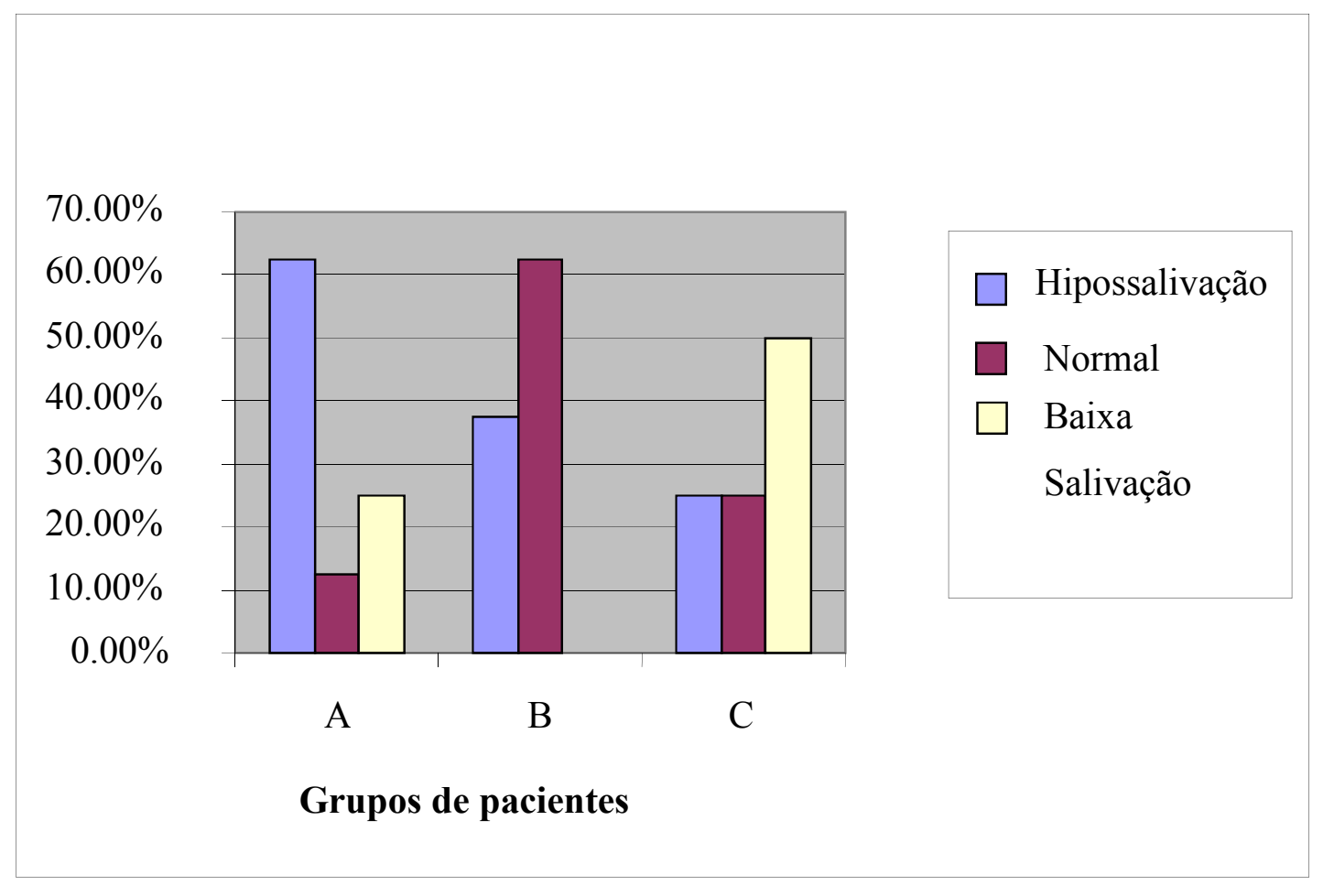

FIGURA 21 - Classificação dos pacientes pesquisados de acordo com o fluxo salivar e distribuídos em cada grupo pesquisado.

Buscou-se relacionar o fluxo salivar com a presença de leveduras na cavidade bucal dos pacientes pesquisados; sendo que o Teste 
do Qui-quadrado não determinou diferenças estatísticas ( $\chi \cdot 2=2,813$ ( $p=$ $0,245)$. Na TABELA 17 e na FIGURA 22 verifica-se que dentre os pacientes com culturas positivas para leveduras, 5 pacientes $(62,50 \%)$ apresentaram hipossalivação, 2 pacientes (25\%) mostraram baixo fluxo salivar e 1 paciente $(12,5 \%)$ encontrava-se com salivação normal. Observou-se que dos 10 pacientes $(41,66 \%)$ que tinham hipossalivação, 2 pacientes (62,5\%) apresentavam amostras positivas para leveduras.

TABELA 17 - Frequência de leveduras de acordo com o tipo de fluxo salivar dos pacientes pesquisados.

\begin{tabular}{lllll}
\hline \multirow{2}{*}{ LEVEDURAS } & \multicolumn{3}{c}{ FLUXO SALIVAR } & \multirow{2}{*}{ TOTAL } \\
\cline { 2 - 4 } & HIPOSSALIVAÇÃO & NORMAL & BAIXO & \\
\hline NEGATIVAS & $5(31,25 \%)$ & $7(43,75 \%)$ & $4(25,00 \%)$ & 16 \\
POSITIVAS & $5(62,52 \%)$ & $1(12,50 \%)$ & $2(25,00 \%)$ & 8 \\
TOTAL & 10 & 8 & 6 & 24 \\
\hline
\end{tabular}

$\chi \cdot 2=2,813$; ns estatística não significante nesta $\left(p^{\prime}=0,245\right)$.

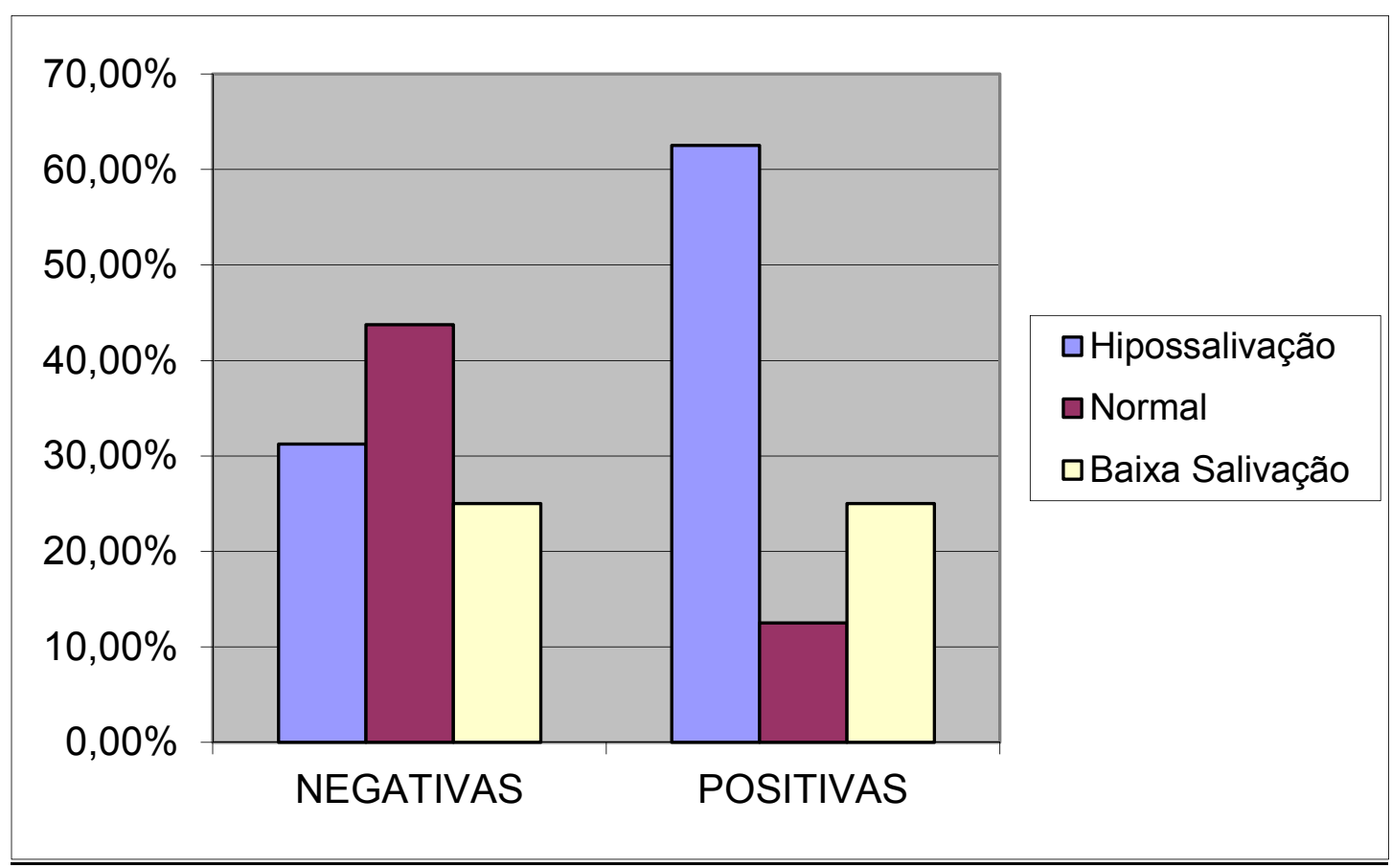

FIGURA 22 - Frequência de leveduras de acordo com o tipo de fluxo salivar dos pacientes pesquisados. 
6 DISCUSSÃO 


\section{DISCUSSÃO}

Os resultados de muitos trabalhos, que tiveram como meta avaliar uma possível correlação entre diabetes mellitus e doença periodontal, têm sido contraditórios, já que alguns não alcançaram tal intento, como os de ALDRIDGE et al. 2, RUHNKE et al. ${ }^{61} \mathrm{e}$ o de SATROWIJOTO et al. ${ }^{66}$, enquanto outros como os de RYLANDER et al. ${ }^{62}$, SANDHOLM et al. ${ }^{64}$, de THORSTENSSON; HUGOSON ${ }^{78}$ e de FIRATLI et al. ${ }^{23}$, evidenciaram que o grau de gengivite e doença periodontal é maior em diabéticos do que em não diabéticos.

Conforme SOSKOLNE; KLINGER ${ }^{72}$, a associação entre a periodontite e o diabetes mellitus poderia ser resultado de pelo menos 2 mecanismos similares, mas platonicamente diferentes: a) uma relação causal direta onde as consequências do diabetes atuariam como modificadores da expressão da doença periodontal ou, b) um defeito patológico comum, que resultaria em um hospedeiro susceptível a uma ou ambas as doenças. Muitos autores, como HUGOSON et al. ${ }^{31}$, THORSTENSSON; DAHLÉN; HUGOSON ${ }^{77}$, parecem aceitar a primeira hipótese, baseada na evidência de que há um risco aumentado nos pacientes diabéticos, para desenvolver a periodontite, o que também é reforçado por estudos que incluem a hiperglicemia e a hiperlipidemia na patogênese das complicações diabéticas e que incluem a periodontite como uma complicação desta. Esta associação, bidirecional, mostra que a prevalência da periodontite não é apenas maior nos diabéticos que nos não diabéticos, mas também que a prevalência de diabetes é maior em pessoas com periodontite do que em indivíduos saudáveis, também, segundo SOSKOLNE; KLINGER ${ }^{72}$.

A presença de leveduras na cavidade bucal é reconhecida, entretanto, sua prevalência em vários tipos de populações, como nos 
comprometidos sistemicamente, deve ser avaliada. E, com esta meta, o presente trabalho procurou identificar a presença de leveduras no sulco gengival de pacientes diabéticos tipo1 e sua provável relação com a doença periodontal. Vinte e quatro indivíduos, de ambos os sexos, foram selecionados e subdivididos em três grupos: pacientes diabéticos tipo 1, na faixa etária de 10 a 19 anos (GRUPO A), pacientes diabéticos tipo 1, com 20 anos ou mais (GRUPO B) e o GRUPO C composto por não diabéticos, portadores de doença periodontal, com idade igual ou superior a 20 anos.

Considerou-se que seria interessante analisar as condições periodontais dos pacientes diabéticos tipo $1 \mathrm{e}$, assim os 16 indivíduos diabéticos foram selecionados simples e aleatoriamente, portanto desconhecendo seu quadro periodontal. Apenas seu quadro sistêmico era sabido, devido aos cuidados necessários no atendimento odontológico, exigidos pelos diabéticos. Buscava-se, também, saber se haveria diferenças entre os pacientes mais jovens e mais velhos, quanto ao seu quadro periodontal, daí o porquê da formação de dois grupos com diabetes mellitus tipo1. Já no grupo controle, a presença de doença periodontal era primordial, pois deveríamos averiguar a presença de leveduras nos sulcos "doentes" e sadios, bem como a comparação destes com os resultados encontrados na saliva, em todos os grupos. Assim, seria relevante estabelecer-se um paralelo entre estes sítios dos grupos controle e diabéticos, onde a presença de leveduras na cavidade bucal já é estabelecida na literatura, mas cuja presença e sua ação no sulco gengival são discutíveis e/ou desconhecidos.

Analisando-se a amostra estudada em relação ao sexo, observou-se que tanto o grupo $\mathrm{B}$, como o grupo $\mathrm{C}$, apresentava números equivalentes de indivíduos de ambos os sexos, enquanto no grupo $A$, havia um predomínio de mulheres (75\%) (Tabela 1).

Preferiu-se escolher indivíduos mais jovens, semelhantes aqueles utilizados por COHEN et al. ${ }^{11}$, bem como, buscou-se excluir outros 
fatores coadjuvantes na instalação da doença periodontal, como as alterações sistêmicas.

Do mesmo modo que fizeram SATROWIJOTO et al. ${ }^{65}$, RAMS; BABALOLA; SLOTS ${ }^{55}$, foram afastados os pacientes que nos últimos 6 meses se submeteram a antibioticoterapia uma vez que os antibióticos combatem as bactérias, concorrentes ambientares dos fungos, favorecendo a proliferação destes, o que poderia ser crítico para os resultados microbiológicos.

Também foram excluídos aqueles indivíduos, que eram portadores de aparelhos ortodônticos, já que estes poderiam colaborar com o maior acúmulo de placa bacteriana, interferindo na resposta tecidual e, consequentemente, nos resultados dos índices periodontais clínicos. Os fumantes não puderam participar deste estudo, pela ação comprovada do tabaco no desenvolvimento da doença periodontal, comentada por IACOPINO ${ }^{32}$.

Neste trabalho, como nos estudos de BARNETT et al. $^{6}$, e ROSENTHAL; ABRAMS; KOPCZYK ${ }^{60}$, foram realizados a anamnese e o exame físico dos pacientes. Aqui, o objetivo foi colher informações que identificassem qualquer situação que pudesse interferir secundariamente na colonização por leveduras na cavidade bucal. No entanto, o nível do comprometimento glicêmico dos pacientes diabéticos era desconhecido, para que não houvesse interferência na obtenção dos dados periodontais.

Enquanto MANFREDI et al. ${ }^{40}$, ao examinarem pacientes diabéticos, detectaram que $3,6 \%$ dos indivíduos estudados apresentavam evidências clínicas de candidose, o presente estudo não demonstrou diferença estatística significante ao inter-relacionar a presença de lesões na mucosa bucal, com o quadro glicêmico do paciente (tabelas 2 e 13), uma vez que o exame físico dos pacientes, não identificou quaisquer sinais ou sintomas que sugerissem a candidose bucal, como no trabalho de WILLIS et 
al. $^{82}$, o que não poderia ser discutido apenas com base em dados clínicos. Por outro lado, outras lesões na mucosa bucal foram encontradas, entre as quais as traumáticas eram as mais comuns, e dentre elas, a mucosa mordiscada, era a mais freqüente.

A condição periodontal dos grupos de pacientes envolvidos neste estudo foi avaliada com base em índices periodontais clínicos, como o índice de placa (IP), o índice gengival (IG), o índice de sangramento gengival (ISG), o nível de inserção clínica (NIC) e a profundidade de sondagem (Tabela 3).

Um estudo prévio de ROSENTHAL; ABRAMS; KOPCZYK 60 , sugeriu que o diabetes mellitus tipo1 poderia influenciar a susceptibilidade e/ou severidade das doenças periodontais. Nos casos em que a gengivite estivesse presente, mas não a periodontite como no trabalho de SANDHOLM et al. ${ }^{66}$, esta era mais severa que nos indivíduos controles e mais severas ainda naqueles diabéticos pobremente controlados.

No presente trabalho, verificou-se uma tendência dos diabéticos a apresentarem uma maior susceptibilidade à doença periodontal, especialmente nos pacientes mais velhos consequentemente com maior duração do diabetes mellitus, uma vez que enquanto nos pacientes diabéticos do grupo A (tabela 3)houve 2,49\% de bolsas com profundidade de sondagem de 4 a $5 \mathrm{~mm}$ e $0,14 \%$ de bolsas com profundidade de sondagem igual ou superior a $6 \mathrm{~mm}$, nos pacientes diabéticos do grupo $B$, nossos dados evidenciaram $11,29 \%$ de bolsas, com profundidade de sondagem entre 4 a $5 \mathrm{~mm}$ e $5,63 \%$ de bolsas, com profundidade de sondagem igual ou superior a $6 \mathrm{~mm}$, cujos valores se aproximam dos valores citados por ROSENTHAL; ABRAMS; KOPCZYK ${ }^{60}$, que ao avaliarem 52 pacientes diabéticos tipo1, detectaram bolsas periodontais em apenas $5,8 \%$ daquela população. Por outro lado, os valores do presente trabalho foram inferiores aos $39 \%$ de periodontite verificados por CIANCIOLLA et al. ${ }^{10}$. Enquanto TERVONEN; KNUUTTILA ${ }^{76}$ sugeriram que os diabéticos, em 
faixa etária semelhante à do grupo $\mathrm{A}$, tinham maior susceptibilidade à doença periodontal, BARNETT et al. ${ }^{6}$ se surpreenderam ao não encontrar periodontite nos diabéticos jovens, mesmo naqueles pobremente controlados, sugerindo haver diferenças entre eles, quanto à susceptibilidade à doença periodontal, que poderia ser maior nos diabéticos jovens. No entanto, concordamos com os mesmos autores, que é inapropriado generalizar este problema, em função de nossos registros terem sido obtidos em uma população pequena.

Ao comparar os dados colhidos no presente trabalho, pôdese demonstrar diferenças estatisticamente significantes entre ambos os grupos diabéticos quanto ao nível de inserção clínica (tabela 4). Enquanto não houve diferenças entre o índice gengival (IG) e o índice de sangramento gengival (ISG), a perda do nível de inserção aumentou em aproximadamente $77,7 \%$ no grupo B em relação ao grupo A. A duração média do diabetes mellitus no grupo $B$ era de 175,5 meses e no grupo $A$ era de 82,1 meses (tabela 1). Estes resultados indicam que o quadro periodontal se agrava à medida que o diabetes mellitus progride, também de acordo com os trabalhos de THORSTENSSON; HUGOSON ${ }^{78}$ (tabela 3 ) e de COHEN et al. ${ }^{11}$, que detectaram um aumento de $38 \%$ nos escores dos índices periodontais clínicos, em relação aos não diabéticos (9\%) após 2 anos de proservação, embora HUGOSON et al. ${ }^{31}$ não tivessem detectado diferenças estatísticas em relação ao quadro periodontal de pacientes diabéticos tipo1 de longa duração, notaram que a destruição periodontal aparecia em faixa etária mais jovem, vindo a sugerir que, provavelmente, a periodontite seria uma complicação do diabetes.

No estudo de DE POMMEREAU et al. $^{18}$, não foram observadas diferenças significativas na perda de inserção e na presença de gengivite entre diabéticos e controles, no entanto, puderam perceber uma maior frequência de gengivite nos diabéticos. Em contrapartida, no presente trabalho, verificou-se que a análise estatística foi diferente ao comparar o índice de placa, o índice de sangramento gengival, o nível de inserção e a 
frequência de sítios com profundidade de sondagem entre 4 a $5 \mathrm{~mm}$, entre os pacientes diabéticos do grupo A e pacientes controle (tabela 4). Estes resultados já eram esperados, considerando que a seleção dos pacientes diabéticos do grupo A foi consecutiva e que os pacientes controle eram portadores de doença periodontal, verificando-se que os índices periodontais clínicos foram significativamente maiores nos pacientes controles (tabela 3), com exceção do índice gengival (IG), que mostrava níveis de gengivite semelhantes entre ambos os grupos, o que sugere maior susceptibilidade dos diabéticos à doença periodontal, considerando que, nem toda gengivite evolui para uma periodontite, uma terapia preventiva deve ser instituída nestes pacientes, pois toda periodontite é precedida de uma gengivite, discutiram SOLSKONE; KLINGER ${ }^{72}$.

Entre os grupos controle e $\mathrm{B}$, a análise estatística também mostrou diferenças estatisticamente significantes em relação aos sítios com profundidade de sondagem de 4 a $5 \mathrm{~mm}$ (tabela 4), percebendo-se maior quantidade de bolsas no primeiro grupo, onde havia doença periodontal préestabelecida. No entanto, observou-se que, apesar de ter havido um índice de placa maior nos pacientes controles, a perda de inserção foi menor que aquela ocorrida nos pacientes diabéticos do grupo $B$, que por sua vez foi significativamente maior que a perda de inserção dos pacientes do grupo $A$ (tabela 3). Estes resultados estão em desacordo com os estudos de THORSTENSSON; HUGOSON ${ }^{78}$, onde a perda de inserção dos pacientes diabéticos mais jovens, com diabetes mellitus de longa duração, foi mais severa que aquela dos não diabéticos na mesma faixa etária, porém era equivalente a dos pacientes diabéticos mais velhos, também com diabetes de longa duração, considerando que encontraram mais bolsas iguais ou superiores a $6 \mathrm{~mm}$, nos paciente diabéticos mais jovens. Estes mesmos autores sugeriram que o surgimento precoce do diabetes mellitus oferece um risco maior para a perda periodontal do que simplesmente a duração da doença. 
Com o intuito de diagnosticar radiograficamente a periodontite, empregaram-se tomadas radiográficas padronizadas periapicais pela técnica da bissetriz (dentes anteriores superiores e inferiores, em número de 6) e as interproximais posteriores (quando necessário de pré-molares e molares separadamente), utilizando-se os posicionadores Rinn XCP (RINN CORPORATION - USA), pela técnica do paralelismo. Os achados radiográficos não foram significativos, semelhante ao que ocorreu com o estudo de TERVONEN; KNUUTTILA ${ }^{76}$, através do qual não encontraram perdas ósseas relevantes, enquanto BARNETT et al. $^{6}$, não encontraram nenhuma evidência radiográfica de perda óssea.

O exame microbiológico foi realizado a partir da amostragem de dois sulcos gengivais interproximais: um saudável e outro comprometido pela gengivite ou doença periodontal, e da saliva de cada participante. Considerando a amostragem simples e aleatória nos diabéticos, selecionouse como sulco saudável, aquele que tivesse ausência de características inflamatórias, enquanto como sulco comprometido, selecionou-se aquele que se apresentasse com quadro de gengivite ou doença periodontal mais evoluído.

A amostragem de cada sulco foi realizada com um cone de papel absorvente, introduzido no local por 10 segundos, após suave higiene supra gengival, enquanto da saliva foi coletada após o teste de fluxo salivar.

Em seguida, a semeadura foi executada assepticamente em placas de Petri contendo Sabouraud dextrose ágar (SDA), conforme FISHER et al. $^{24}$, acrescido de $100 \mu \mathrm{g} / \mathrm{ml}$ de cloranfenicol, também realizado por MONTEIL; MADINIER; FICHOUX ${ }^{9}$. As placas semeadas foram incubadas em estufa a $30^{\circ} \mathrm{C}$ por 5 dias, sendo aguardados mais 5 dias para os casos que não apresentaram crescimento, enquanto FISHER et al. $^{24}$, utilizaram uma temperatura de $37^{\circ} \mathrm{C}$ por 2 dias. 
Quanto à presença de leveduras, oito indivíduos (33,33\%) se apresentaram colonizados dentre os 24 participantes desta pesquisa, no entanto, não houve significância estatística ao inter-relacionar os resultados positivos e negativos destas culturas entre os diferentes grupos de pacientes estudados. Além disto, as condições periodontais dos pacientes negativos para leveduras não foram diferentes dos pacientes positivos, uma vez que a análise estatística não foi significante ao serem comparados os dados periodontais clínicos (tabela 6). Fazendo-se uma análise em relação ao total de sítios amostrados (72), os 13 sítios (18\%) com culturas positivas para leveduras (Tabela 8), não foram significativos. Por outro lado, enquanto os grupos A e C apresentaram-se cada qual, com a mesma quantidade de indivíduos positivos (23,08\%), o grupo B comportava $53,85 \%$ dos resultados positivos e com maior concentração das leveduras na saliva (tabelas 5 e 7). Da mesma forma que REYNAULD et al. ${ }^{59}$, com exceção de um caso, não encontramos leveduras em todas as amostras de um mesmo paciente (tabela 7). Assim, os resultados desta comparação não permitem generalizar a afirmativa que os pacientes diabéticos tipo 1 poderiam apresentar mais leveduras que os pacientes controles.

Ao estabelecermos uma comparação em relação à presença de leveduras nos sítios amostrados, dos 3 grupos estudados, não se observaram diferenças estatisticamente significantes, entre diabéticos tipo 1 (grupos A e B) e os indivíduos controle (tabela 9), tendo sido verificado que, nos 8 pacientes controles, o número de sítios (3 locais: 1 no sulco saudável, 1 no sulco comprometido e 1 na saliva) com resultados positivos nas culturas para leveduras foi menor em relação aos 16 pacientes diabéticos (10 locais: 3 no grupo A e 7 no grupo B) (tabela 8), apesar da doença periodontal evidente nos primeiros.

Apesar dos pacientes diabéticos estarem em número duas vezes maior que os pacientes controles, observou-se que o número de sulcos gengivais comprometidos, infectados entre os pacientes diabéticos (1 paciente do grupo A e 2 pacientes do grupo B) foi maior que nos pacientes 
controles (3:1), embora não mostrando diferenças estatísticas (tabelas $8 \mathrm{e}$ 9), bem como o grupo B absorvia o maior número de resultados positivos dos sulcos saudáveis (23,08\%). Assim, os resultados do presente estudo, sugerem uma maior predisponência dos pacientes diabéticos tipo1 à presença de leveduras nos sulcos gengivais comprometidos e saudáveis. Entretanto, isto não significaria que a presença destes microorganismos nos sulco gengivais pudesse interferir com o quadro periodontal do paciente, considerando que os índices periodontais clínicos não apresentaram diferenças estatísticas significantes entre os pacientes portadores e não portadores de leveduras (tabela 6), nem que se pudesse afirmar que haveria influências sobre as condições periodontais, com a evolução do diabetes mellitus, uma vez que, com exceção da perda de inserção clínica (NIC) ter sido maior no grupo $B$, não houve diferenças significantes entre os dois grupos diabéticos (tabela 4). Entretanto, uma vez que as leveduras preferem se desenvolver em meios aeróbicos, questionar-se-ia se poderiam fazê-lo em bolsas profundas, competindo com microorganismos aeróbios residentes, provocando a "falência" periodontal, segundo DAHLÉN; WIKSTRÖM ${ }^{15}$. Considerando que as leveduras são membros transitórios da microbiota bucal, podendo ocorrer na cavidade bucal transitoriamente e serem eliminadas com o tempo, a relevância para a progressão e para a não resolução da doença periodontal deve ser questionada. Principalmente, ao indicar uma antibioticoterapia que poderia propiciar o risco de selecionar tais microorganismos causando superinfecções.

Da mesma forma, a questão sobre o papel destes microorganismos oportunistas no reconhecido quadro periodontal diabético poderia ser levantada, considerando que este estudo não investigou a história farmacológica dos pacientes diabéticos tipo1, em prazo superior aos 6 meses prévios ao início desta pesquisa, ainda que os pacientes diabéticos teriam maior predisposição às infecções, quando ficariam mais expostos à diversas antibioticoterapias, quer seja por questões médicas ou 
odontológicas, como realizadas por HELOVUO; HAKKARAINEN; PAUNIO 29

Existem controvérsias se as espécies de Candida seriam mais comuns na cavidade bucal de diabéticos que nos não diabéticos e se isto estaria relacionado ao controle glicêmico, segundo FISHER et al. ${ }^{24}$. No presente estudo, apesar de não ter havido diferenças estatisticamente significantes entre as quatro espécies identificadas nos sítios amostrados, a C. albicans $(61,53 \%)$ foi a mais encontrada nos sítios colonizados, um pouco menos que aquela encontrada por WILLIS et al. ${ }^{82}(77 \%)$, um pouco mais que COSTA et al. ${ }^{12}(56,25 \%)$, mas uma frequência bem mais elevada que aquela demonstrada por FISHER et al. ${ }^{24}$ (43\%) e SLOTS; FEIK; RAMS ${ }^{70}(13,6 \%)$. Enquanto, no trabalho de SATROWIJOTO et al. ${ }^{66}$, a C. albicans foi encontrada, esporadicamente, apenas nas bolsas periodontais (Tabela 10), no presente estudo foram encontradas em quantidade semelhante nos três sítios amostrados (tabela 10).

Como segunda levedura mais comum, a Candida glabrata, que se manifestou apenas no sulco saudável, dividiu sua colocação com a Candida parapsilosis, encontrada na mesma quantidade de sulcos saudáveis e saliva, quando cada espécie correspondeu a 15,38\% das amostras, bem mais que os $3,46 \%$ encontradas por WILLIS et al. ${ }^{82}$. Por último, 7,69\% dos sítios foram colonizados pelo Trischoporon ovóides, encontrados apenas na saliva (Tabela 10); averiguando-se que podem ser encontrados gêneros de fungos diferentes da Candida spp., considerados emergentes como agentes de infecção em pacientes imunosuprimidos.

O exame de hemoglobina glicosilada utilizado para monitorizar o controle glicêmico foi empregado para dividir os 16 diabéticos selecionados, no presente trabalho, em três grupos: pacientes bem controlados, moderadamente controlados e pobremente controlados, como fizeram TERVONEN; KNUUTTILA ${ }^{76}$, no entanto analisou-se, como referência no presente estudo, o valor de $11 \%$ nas taxas de hemoglobina 
glicosilada, proposta por ROSENTHAL; ABRAMS; KOPCZYK ${ }^{60}$, para indicar um pobre controle diabético.

A média de valores de hemoglobina glicosilada encontrada, no presente estudo, foi de 9,25\% nos DMC e 12,82\% nos DPC, estando esta última média bem mais elevada que a média das taxas de hemoglobina glicosilada $(10,7 \%)$ dos pacientes DPC fornecida por SAFKAN-SEPPÄLÄ; AINAMO ${ }^{63}$, demonstrando que realmente o controle glicêmico de nossa população DPC era negligente.

SAFKAN-SEPPÄLLÄ; AINAMO ${ }^{63}$, comentaram que mesmo os pacientes bem controlados, eventualmente apresentavam elevações da hemoglobina glicosilada, indicando que as medidas terapêuticas convencionais são ineficazes para controlar de forma absoluta a hiperglicemia. Neste estudo, foi encontrado somente 1 paciente diabético bem controlado, enquanto que não se observaram diferenças no número de indivíduos entre os pacientes diabéticos moderadamente controlados e pobremente controlados, mas houve grande redução no número de pacientes pobremente controlados no grupo $B$, em relação ao grupo $A$, sugerindo que possíveis fatores comportamentais poderiam favorecer ao difícil controle glicêmico no grupo A (tabela 11).

No presente estudo, ao estabelecer um paralelo entre os quadros periodontais dos dois grupos glicêmicos quanto à hemoglobina glicosilada (DMC e DPC), não se verificou diferença estatisticamente significante entre os índices periodontais clínicos, com exceção dos níveis de placa significantemente maiores nos pacientes DMC, sugerindo-se que o controle glicêmico não tem efeito direto sobre o periodonto, estando de acordo com o trabalho de SATROWIJOTO et al. ${ }^{65}$, que também observaram em um estudo posterior de SATROWIJOTO et al. ${ }^{66}$, que a condição periodontal clínica apenas melhoraria mediante o aperfeiçoamento da higiene bucal, contrariando o esperado: que o grupo de pacientes DPC mostrasse quadro periodontal mais severo, como nos trabalhos de 


\section{SAFKAN-SEPPÄLLÄ; AINAMO ${ }^{63}$, SEPÄLLÄ; SEPÄLLÄ; AINAMO ${ }^{68}$, SEPPÄLÄ; AINAMO ${ }^{67}$ e SYRJÄLÄ; KNECKT; KNUUTTILA ${ }^{73}$.}

Da mesma forma, os resultados de PINSON et al. ${ }^{54}$, não foram significantes ao relacionarem a severidade da doença periodontal e a duração do diabetes mellitus ou o nível de controle glicêmico. Em contrapartida, ROSENTHAL; ABRAMS; KOPCZYK ${ }^{60}$ encontraram uma concentração de hemoglobina glicosilada significantemente menor no grupo com periodontite, atribuindo esta situação ao fato de que 2 dos 3 diabéticos portadores de periodontite tinham história pregressa de controle glicêmico extremamente pobre e tornaram-se os que melhor controlavam seu quadro sistêmico, no momento do estudo.

No atual estudo não foi verificada a associação entre a presença de $\boldsymbol{C}$. albicans no sulco gengival de diabéticos e o equilíbrio glicêmico do paciente (tabela 14), corroborando com os resultados de FISHER et al. ${ }^{24}$ e MANFREDI et al. ${ }^{40}$. Por outro lado, pudemos conferir que dentre os pacientes que apresentavam leveduras na cavidade bucal, os pacientes diabéticos moderadamente controlados apresentavam o dobro de casos que os pacientes diabéticos pobremente controlados, sendo que $50 \%$ de todos os casos de leveduras eram pacientes diabéticos moderadamente controlados pertencentes ao grupo B (tabela 15), diferente do esperado, quando organismos mais comprometidos sistemicamente favoreceriam a maior proliferação de leveduras. Já que, as leveduras subgengivais não poderiam residir em organismos saudáveis por muito tempo o controle glicêmico do paciente diabético poderia colaborar para a redução das leveduras RAMS; BABALOLA; SLOTS ${ }^{55}$.

No estudo de TWETMAN; ARONSSON; BJÖRKMAN ${ }^{80}$, foi observado que fluxo salivar era significativamente menor entre as crianças diabéticas (1,2 $\pm 0,7 \mathrm{ml} / \mathrm{min})$, em relação a seus controles saudáveis (1,5 \pm $0,5 \mathrm{ml} / \mathrm{min}$ ), demonstrando que um dos sintomas do diabetes mellitus era a xerostomia. 
O presente estudo também utilizou o teste do fluxo salivar, para analisar se haveria diferenças entre os grupos pesquisados, bem como se a diminuição salivar poderia interferir na presença de leveduras na cavidade bucal. Verificou-se que a hipossalivação era maior entre os membros do grupo A (tabela 16), diminuindo tanto naqueles pacientes do grupo $B$, onde os níveis da hemoglobina glicosilada eram melhores, e mais ainda nos indivíduos saudáveis do grupo C. O grupo B concentrava o maior número de pacientes com fluxo salivar normal, não apresentando representantes com baixa salivação; enquanto o grupo C absorvia $50 \%$ dos pacientes com baixa salivação, sugerindo que a relação doença periodontal e fluxo salivar fosse melhor esclarecida em estudos posteriores.

Como MANFREDI et al. $^{40}$, que não conseguiram comprovar que as complicações diabéticas pudessem interferir na presença de leveduras da cavidade bucal, de pacientes diabéticos, o presente trabalho não constatou diferença estatística entre a presença de leveduras e o fluxo salivar. Todavia, observou-se que 10 pacientes $(41,66 \%)$, entre os membros dos 3 grupos estudados, tinham hipossalivação e, dentre estes, 62,5\% das amostras eram positivas para leveduras (tabela 17). Verificou-se, também, que o único caso que relatava "boca seca", pertencia ao grupo B e apresentava leveduras nos três sítios amostrados, sugerindo que novas pesquisas fossem feitas a este respeito, com um grupo maior e específico de diabéticos xerostômicos. 
7 CONCLUSÃO 


\section{CONCLUSÃO}

Baseado nos resultados obtidos neste trabalho e segundo a metodologia empregada, pôde-se concluir que:

1.(a) há uma leve tendência dos pacientes diabéticos do tipo 1 a uma maior susceptibilidade à doença periodontal, agravando à medida que o diabetes mellitus evolui, parecendo ser pior nos pacientes de longa duração que naqueles com menor tempo de exposição ao diabetes mellitus, independente do controle glicêmico. (b) As condições gerais da mucosa são semelhantes entre pacientes diabéticos e não diabéticos.

2.A colonização por leveduras tende a ser maior nos sulcos gengivais, saudáveis e comprometidos, e na saliva de pacientes diabéticos do tipo 1 , que de pacientes não diabéticos, com predomínio de C. albicans. A presença de leveduras nos sulcos gengivais não interfere nas condições periodontais

3. Não parecem existir diferenças significativas na frequência de leveduras em pacientes diabéticos do tipo1, moderadamente e pobremente controlados, embora tenha ocorrido uma maior tendência para os primeiros.

4.Considerando as colocações acima e, ainda, que $41,66 \%$ dos pacientes que apresentaram hipossalivação apresentaram leveduras, sugere-se que novas pesquisas sejam realizadas, analisando-se os aspectos periodontais, em uma amostra maior. 
${ }^{1}$ NBR 10719 da ABNT (Associação Brasileira de Normas Técnicas) 
REFERENCIAS BIBLIOGRÁFICAS 


\section{Referências Bibliográficas ${ }^{2^{\star}}$}

AINAMO, J.; BAY, I. Problems and proposals for recording gingivitis and plaque. Int. dent. j., v. 25, n. 4, p. 229-35, Dec. 1975.

ALDRIDGE, J. P. et al. Single-blind studies of the effects of improved periodontal health on metabolic control in type 1 diabetes mellitus. J. clin. Periodont., v. 22, n. 4, p. 271-5, Apr. 1995.

AMERICAN ASSOCIATION OF PERIODONTOLOGY. Diabetes and periodontal diseases (position paper). J. Period., v. 70, n. 1, p. 935-49, Aug. 1999. and periodontal diseases. J.Period., v. 71, p. 664-78, 2000.

ARENDORF, T. M.; WALKER, D. M. The prevalence and intraoral distribution of Candida albicans in man. Arch. oral biol., v. 24, p. 1-10, 1980.

BARNETT, M. L. et al. Absence of periodontitis in a population of insulin-dependent diabetes mellitus (IDDM) patients. J. Period., v. 55 , n. 7 , p. 402-5, July 1984.

BAY, I.; AINAMO, J.; GAD, T. The response of young diabetics to periodontal treatment. J. Period., v. 45, n. 11, p. 806-8, Nov. 1974.

\footnotetext{
2 * Normas recomendadas para uso no âmbito da Universidade de São Paulo, com base no documento "Referências Bibliográficas: Exemplos", emanados do Conselho Supervisor do Sistema Integrado de Bibliotecas da USP, em reunião de 20 de setembro de 1990.
} 
8 BIRMAN, E. G. Doenças infecciosas: candida e candidoses. IN: TOMMASI, A. F. Diagnóstico em patologia bucal. $3^{a}$. ed. São Paulo: Pancast editora, 2002. Cap.11, p. 198-202.

9 CARRANZA, F. A. Etiologia das doenças periodontais. IN: CARRANZA, F.A.; NEWMAN, M.G. Periodontia clínica. 8. a. ed. Rio de Janeiro: Guanabara-Koogan, 1997. p. 196-199.

10 CIANCIOLA, et al. Prevalence of periodontal disease in insulindependent diabetes mellitus (juvenile diabetes). J. Amer. dent. Ass., v. 104, n. 5, p. 653-60, May 1982.

11 COHEN, D. W. et al. Diabetes mellitus and periodontal disease: two-year longitudinal observations. Part 1. J. Periodont., v. 41, n. 12, p. 709-12, Dec. 1970.

12 COSTA, L. A. S. S. et al. Detecção de leveduras isoladas de lesões da cavidade bucal de pacientes da clínica de odontologia da Universidade de Ribeirão Preto, An Inic Cient. Pesqui da Univ. Ribeirão Preto, v. 2, n. 1, p. 36-52, 2001.

13 CUDWORTH, A. G. The aetiology of diabetes mellitus. Br. J. Hosp. Med., v. 16, p. 207-16, 1976 apud GALE, E. A. M. The Discovery of diabetes type 1. Diabetes, v. 50, p. 217-26, 2001. http://diabetes.diabetesjounals.org/misc/terms.html

14 DAHLÉN, G. et al. A comparison between two transport for saliva and subgingival samples. Oral Microbiol. Immunol., v. 8, n. 6, p. 375-82, Dec. 1993.

15 DAHLÉN, G.; WIKSTRÖM. Ocurrence of enteric rods, Staphylococci and Candida in subgingival samples. Oral Microbiol. Immunol., v. 10, n. 1, p. 42-6, Feb. 1995. 
16 DARWAZEH, A. M. G. et al. Mixed salivary glucose levels and candidal carriage in patients with diabetes mellitus. J. oral Path. Med., v. 20, n. 6, p. 280-3, July 1991.

17 DARWAZEH, et al. The effect of exposure to chlorhexidine gluconate in vitro and in vivo adesion of Candida albicans to buccal epithelial cells from diabetic and non-diabetic subjects. J. oral Path. Med., v. 23, n. 3, p. 130-2, Mar. 1994.

18 DE POMMEREAU, V. et al. Periodontal status in insulindependent diabetic adolescents. J. clin Periodont., v. 19, n. 9, p. 628-32, Oct. 1992.

19 DRAPER, G.; DUPURTUIS, C. W.; CAUGHEY, J. L. The differentiation by constitutional methods between pancreatic diabetes and diabetes of pituitary origin. Trans. Am. Assoc. Phys., v. 55, p. 146-53, 1940 apud GALE, E. A. M. The discovery of diabetes type 1. Diabetes, v. 50, p. 217-26, 2001. http://diabetes.diabetesjounals.org/misc/terms.html

20 DUNNING, J. M.; LEACH, L. B. Gingival bone count: a method for epidemiological study of periodontal disease. J. dent. Res., v. 39, p. 506, 1960 apud SPOLSKY, V. W. Epidemiologia das doenças gengival e periodontal. In: CARRANZA, F. A. Periodontia Clínica. 7.ed. Rio de Janeiro: Guanabara-Koogan, 1992. cap. 5, p. 65-84.

21 EPSTEIN, J. B.; TRUELOVE, E. L.; IZUTZU, K. T. Oral candidiasis: pathogenesis and host defense. Rev. Infect. Dis., v. 6, n. 1, p. 96-106, Feb. 1984. I ABSTRACT Medline n. 6369484 
22 FALTA, W.; BOLLER, R. Insularer und insulinresistenter diabetes. Klin Wochenschr, v. 10, p. 438-43, 1931 apud GALE, E. A. M. The discovery of diabetes type 1 . Diabetes, v. 50, p. 217-26, 2001.

http://diabetes.diabetesjounals.org/misc/terms.html

23 FIRATLI, E. et al. Serum fructosamine correlates with gingival index in children with insulin-dependent diabetes mellitus (IDDM). J. clin. Periodont., v. 21, n. 8, p. 565-8, Sep. 1994.

24 FISHER, B. M. et al. Carriage of Candida species in the oral cavity in diabetic patients: relationship to glycaemic control. J.oral Path., v. 16, n. 5, p. 282-4, May 1987.

25 GALE, E. A. M. The Discovery of diabetes type 1. Diabetes, v. 50 ,

p. 217-26, 2001.

http://diabetes.diabetesjounals.org/misc/terms.html

26 GOTEINER, D. et al. Periodontal and caries experience in children with insulin-dependent diabetes mellitus. J. Amer. dent. Assoc., v. 113, n. 2, p. 277-9, Aug. 1986.

27 HANNULA, J. et al. Subgingival strains of Candida albicans in relation to geograpical origin and occurrence of periodontal pathogenic bacteria. Oral Microbiol. Immunol., v. 16, n. 2, p. 113-8, Apr. 2001.

28 HARLEY, G. Diabetes, its various forms and different treatments. London, Walton and Mabberley,1866 apud GALE, E.A.M. The Discovery of diabetes type 1. Diabetes, v. 50, p. 217-26, 2001. http://diabetes.diabetesjounals.org/misc/terms.html 
HELOVUO, H.; HAKKARAINEN, K.; PAUNIO, K. Changes in prevalence of subgingival enteric rods, sthaphylococci and yeasts after treatment with penicillin and erythromycin. Oral microbiol. Immunol., v. 8, n. 2, p. 75-9, apr. 1993.

HESTER, et al. Oral carriage of Candida in healthy and HIVseropositive persons. Oral Surg., v. 76, n. 5, p. 570-2, Nov. 1993. J. clin Microbiol., v.32, n.9, p. 2092-8, Sep. 1994.

HUGOSON, A. et al. Periodontal conditions in insulin-dependent diabetics, J. clin. Periodont., v. 16, n. 4, p. 215-23, Apr. 1989.

IACOPINO, A. M. Periodontitis and diabetes interrelationships: role of inflammation. Ann. Periodontol., v. 6, n. 1, p. 125-37, Dec. 2001.

KORNMAN, K. S.; PAGE, R. C.; TONETTI, M. S. The host response to the microbiol challenge in periodontitis: assembling the players. Review. Periodontology 2000, v. 14, p. 33-53, June 1997.

LALLA, R. V.; D'AMBROSIO, J. A. Dental management considerations for the patient with diabetes mellitus. J. Amer. dent. Ass., v. 132, n. 10, p. 1425-32, Oct. 2001.

35 LANCEREAUX, E. Le diabete maigre: ses symptomes, son evolution, son prognostie et son traitement. Un. Med. Paris, v. 20 , p. 205-11,1880 apud GALE, E. A. M. The Discovery of diabetes type 1. Diabetes, v. 50, p. 217-26, 2001. http://diabetes.diabetesjounals.org/misc/terms.html

36 LARONE, D. H. Medically important fungi. A guide to identification. Washington: AMS press, 1995. 
37 LISTGARTEN, M. A.; LAI, C. H.; YOUNG, V. Microbial composition and pattern of antibiotic resistence in subgengival microbial samples from patients with refractory periodontitis. J. Periodont., v. 64, n. 3, p. 155-61, Mar. 1993.

38 LÖE, H. The gingival index, the plaque index and the retention index system. J. Periodontol, v. 38, p. 610, 1967.

39 LOPES, F. A. M.; TRAMONTINA, V.; MORITZ, E. S. Tratamento periodontal em pacientes diabéticos. JBE, ano 2, n. 4, p. 58-62, jan. /fev. /mar. 2001.

40 MANFREDI, M. et al. The isolation, identification and molecular analysis of Candida spp isolated from the oral cavities of patients with Diabetes Mellitus. Oral Microbiol. Immunol., v. 17, n. 3, p. 181-5, June 2002.

41 MATA, A. L. et al. Clonal variability among oral Candida albicans assessed by allozyme electrophoresis analysis, Oral Microbiol. Immunol., v. 15, n. 6, p. 350-4, Dec. 2000.

42 MEALLEY, B. Influence of periodontal infections on systemic health. Periodontology 2000, v. 21, p. 197-209, Oct. 1999.

43 MENÉNDEZ, O. R. Saúde e doença em estomatologia pediátrica. IN: TOMMASI, A.F. Diagnóstico em patologia bucal. 3. ed. São Paulo: PANCAST editora, 2002. cap. 29, p. 496-526.

44 MENDIETA, C.; REEVE, C.M. Periodontal manifestation of systemic diseases and management of patients with systemic diseases. Curr. Opinion Periodont., p.18-27, 1993. IN: LOPES, F. A. M.; TRAMONTINA, V.; MORITZ, E. S. Tratamento 
periodontal em pacientes diabéticos. JBE, ano 2, n. 4, p. 58-62, jan./fev./mar. 2001.

MINISTÉRIO DA SAÚDE. Estudo multicêntrico sobre a prevalência do diabetes mellitus no Brasil. Informe Epidemiológico do SUS, v. 1, p. 47-73, 1992. Disponível na Internet. http://tabnet.datasus.gov.br/cgi/idb1998/fqd09.htm

46 MISHRA, S. K et al. Stress, immunity and mycotic diseases. Review. J. Med. Veter. Mycol., v. 32, Suppl, p. 406, 1994. apud REYNAULD, A. H. et al. Yeasts in periodontal pockets. J. clin. Periodont., v. 28, n. 9, p. 860-4, Sep. 2001.

47 MONTEIL, R. A.; MADINIER, I.; FICHOUX, Y. In vitro antifungal resistance of oral Candida albicans strains in non-AIDS patients. Oral Microbiol. Immunol., v. 12, n. 2, p. 126-8, Apr. 1997.

48 MOORE, V. H. et al. Periodontal microflora of HIV positive subjects with gingivitis or adult periodontitis. J. Periodont., v. 64, p. 48-56, 1993.

NAVARRO, M. F. L.; CÔRTES, D. F. Avaliação e tratamento do paciente com relação ao risco de cárie. Maxi-odonto: dentística, v. 1, n. 4, p. 1-19, jul./ago. 1995.

50 ODDEN, et al. Candidal infection on the gingiva in HIV-infected persons. J. oral. Path. Med., v. 23, n. 4, p. 178-83, Apr. 1994.

51 PETERSON, D. E. et al. Microbiology of acute periodontal infection in myelosuppressed cancer patients. J. clin. oncol., v. 5, n. 9, p. 1461-8, Sep. 1987./ ABSTRACT medline n. 46655 
52 PILATTI, G. L.; TOLEDO, B. E. C.; EL GUINDY, M. Diabetes mellitus e doença periodontal. Rev. ABO Nac., v. 3, n. 5, p. 3247, out./nov. 1995.

53 PINCUS, G.; JOSLIN, E.P.; WHITE, P. Age-incidence relations in diabetes mellitus. Am. J. Med. Sci., v. 188, p. 116-21, 1934 apud GALE, E. A. M. The discovery of diabetes type 1. Diabetes, v. 50, p. 217-26, 2001. http://diabetes.diabetes jounals.org/misc/terms.html

54 PINSON, M. et al. Periodontal disease and type 1 diabetes mellitus in children and adolescents. J. clin. Periodont., v. 22, n. 2, p. 118-23, Feb. 1995.

55 RAMS, T. E.; BABALOLA, O. O.; SLOTS, J. Subgiginval occurrence of enteric rods, yeasts and staphylococci after systemic doxycycline therapy. Oral Microbiol. Immunol., v. 5, n. 3, p. 166-8, June 1990.

56 RAMS, T. E.; SLOTS, J. Candida biotype in human adult periodontitis. Oral Microbiol. Immunol., v. 6, n. 3, p. 191-2, June 1991.

57 REES, T. D. Periodontal management of the patient with diabetes mellitus. Periodontology 2000, v. 23, p. 63-72, June 2000.

58 REPORT OF COMMITTEE ON THE DIAGNOSIS AND CLASSIFICATION OF DIABETES MELLITUS. Diabetes care, v. 26, p. 55- 520, 2003.

59 REYNAULD, A. H. et al. Yeasts in periodontal pockets. J. clin Periodont., v. 28, n. 9, p. 860-4, Sep. 2001. 
60 ROSENTHAL, I. M.; ABRAMS, H.; KOPCZYK, R. A. The relationship of inflammatory periodontal disease to diabetic status in insulin-dependent diabetes mellitus patients. J. clin. Periodont., v. 15, n. 7, p. 425-9, July 1988.

61 RUHNKE, M. et al. Emergence of fluconazole- resistant strains of Candida albicans in patients with recurrent oropharyngeal candidosis and human immunodeficiency virus infection. J. clin. Microbiol., v. 32, n. 9, p. 2092-8, Sep. 1994.

62 RYLANDER, $H$. et al. Prevalence of periodontal disease in young diabetics. J. clin. Periodont., v. 14, n. 1, p. 38-43, Jan. 1987.

63 SAFKAN-SEPPÄLÄ, B.; AINAMO, J. Periodontal conditions in insulin-dependent diabetes mellitus. J. clin Periodont., v. 19, n. 1, p. 24-9, Jan. 1992.

64 SANDHOLM, L. et al. Periodontal status of Finnish adolescents with insulin-dependent diabetes mellitus. J. clin. Periodont., v. 16, n. 10, p. 617-20, Nov. 1989.

65 SASTROWIJOTO, S. H. et al. Improved metabolic control, clinical periodontal status and subgingival microbiology in insulin-dependent diabetes mellitus. J. clin. Periodont., v. 17, n. 4, p. 233-42, Apr. 1990.

66 SASTROWIJOTO, S. H. et al. Periodontal condition and microbiology of healthy and diseased periodontal pockets in type 1 diabetes mellitus patients. J. clin. Periodont., v. 16, n. 5, p. 316-22, May 1989. 
67 SEPPÄLÄ, B.; AINAMO, J. A site-by-site follow-up study on the effect of controled versus poorly controled insulin-dependent diabetes mellitus. J. clin. Periodont., v. 21, n. 3, p. 161-5, Mar. 1994.

68 SEPPALÄ, B.; SEPPÄLÄ, M.; AINAMO, J. A longitudinal study on insulin-dependent diabetes mellitus and periodontal disease. J. clin. Periodont., v. 20, n. 3, p. 161-5, Mar. 1993.

69 SILNESS, P.; LÖE, H. Periodontal disease in pregnancy. Acta Odontol scand., v. 22, p. 121-135, 1964.

70 SLOTS, J.; FEIK, D.; RAMS, T. E. Age and sex relationship of superinfecting microorganisms in periodontitis patients. Oral Microbiol. Immunol., v. 5, n. 6, p. 305-8, Dec. 1990.

71 SLOTS, J.; RAMS, T. E.; LISTGARTEN, M. A. Yeasts, enteric rods and pseudomonads in the subgingival flora. Of severe adult periodontitis. Oral Microbiol. Immunol., v. 3, n. 2, p. 47-52, June 1988 apud REYNAULD, A. H. et al. Yeasts in periodontal pockets. J. clin Periodont., v. 28, n. 9, p. 860-4, Sep. 2001.

72 SOLSKONE, W. A.; KLINGER, A. The relationship between periodontal diseases and diabetes: an over view. Ann. Periodont., v. 6, n. 1, p. 91-8, Dec. 2001.

73 SYRJÄLÄ, A. M. H.; KNECKT, M. C.; KNUUTTILA, M. L. E. Dental self- efficacy as a determinant to oral health behaviour, oral hygiene and $\mathrm{HbA} 1 \mathrm{c}$ level among diabetic patients. J. clin. Periodont., v. 22, n. 6, p. 449-58, June 1995. 
74 TAYLOR, G. W. Periodontal treatment and its effects on glycaemic control: A review of the evidence. Oral Surg., v. 87, n. 3, p. 311-6, Mar. 1999.

75 TAYLOR, G. W. Biderectional interrelationships between diabetes and periodontal diseases: an epidemiologic perspective. Ann. Periodontol., v. 6, n. 1, p. 99-112, Dec. 2001.

76 TERVONEN, T.; KNUUTTILA, M. Relation of diabetes control to periodontal pocketing and alveolar bone level. Oral Surg., v. 61, n. 4, p. 346-349, Apr. 1986.

77 THORSTENSSON, H.; DAHLËN, G.; HUGOSON, A. Some suspect periodonto pathogens and serum antibody response in adult long duration insulin-dependent diabetics. J. clin. Periodont., v. 22, n. 6, p. 449-58, June 1995.

78 THORSTENSSON, H.; HUGOSON A. Periodontal disease experience in adult long-duration insulin-dependent diabetics. J. clin. Periodont., v. 20, n. 5, p. 352-8, May 1993.

79 TOMMASI, A. F. Lesões brancas. IN: Diagnóstico em patologia bucal. 3. ed. São Paulo: Pancast editora, 2002. cap. 9, p.159-70.

80 TWETMAN, S.; ARONSSON, S.; BJÖRKMAN, S. mutans streptococci and lactobacilli in saliva from children with insulindependent diabetes mellitus. Oral Microbiol. Immunol., v. 4, n. 3, p. 165-8, Sep. 1989.

81 WESTFELT, E. et al. The effects of periodontal therapy in diabetics: results after 5 years. J. clin. Periodont., v. 23, n. 2, p. 92-100, Feb. 1996. 
82 WILLIS, A. M. et al. Isolation of C. dubliniensis from insulin-using diabetes mellitus patients. J. oral Path. Med., v. 29, n. 2, p. 8690, Feb. 2000.

83 WILLIS, A. M. The influence of antifungal drugs on virulence properties of Candida albicans in patients with diabetes mellitus. Oral Surg., v. 91, n. 3, p. 317-21, Mar. 2001.

84 YUAN, K. et al. Detection of putative periodontal pathogens in non-insulin-dependent diabetes mellitus and non- diabetes mellitus by polymerase chain reaction. J. Periodont. Res., v. 36, n. 1, p. 18-24, Feb. 2001. 
ABSTRACT 


\section{ABSTRACT}

\section{COMPARATIVE STUDY OF YEAST COLONIZATION IN THE GINGIVAL CREVICE OF DIABETES MELLITUS TYPE 1 PATIENTS}

This work assessed (a) the differences of periodontal and soft tissue conditions, between diabetics type 1 patients, (b) the prevalence and comparison of yeast in gingival and saliva, (c) possible association between yeast with glycaemic conditions of the diabetic patients. Twenty-four patients were subdivided in 3 groups: diabetic subjects aging from 13 to 19 years (A) and aging from 20 or more years $(B)$ and healthy controls (C) with periodontal diseases, aging from 20 or more years. There were performed the hemoglobin glycated test, radiological examination, anamnestic information, periodontal and soft tissues condition, salivary flow and microbiological analysis of the gingival and saliva; the plaque index, gingival index, bleeding sulcular index, clinical attachment level and probing depth were recorded. There were no significant differences in relation to the periodontal and mucosa conditions between diabetic patients, exception was to group $B$ that showed $77 \%$ more attachment loss than group $A$. The results showed no significant differences in the prevalence of yeast, however there were twice more numbers of yeast in group B. C. albicans was the most frequent detected yeast. Although data from this study were not significant, a slightly tendency to a high prevalence of yeast and an increased susceptibility to periodontal diseases in diabetic population were shown. So, it would be prudent to elucidate in a greater population. 